\title{
MACRONUTRIENTES EM KIWI CULTIVARES BRUNO E MONTY: TEORES, SINTOMAS DE CARÊNCIA E EXPORTAÇÃO PELOS FRUTOS
}

\author{
TÂNIA APARECIDA DE NUCCI
}

Engenheira Agrônoma

Orientador: Prof. Dr. FRANCISCO ANTONIO MONTEIRO

\begin{abstract}
Dissertação apresentada à Escola Superior de Agricultura "Luiz de Queiroz", da Universidade de São Paulo, para obtenção do título de Mestre em Agronomia, Área de concentração: Solos e Nutrição de Plantas.
\end{abstract}

PIRACICABA

Estado de São Paulo - Brasil Julho - 1996 
Dados Internacionais de Catalogaçāo na Publicação (CIP) DIVISÃo DE BIBLIOTECA E DOCUMENTAÇẪO - Campus “Luiz de Queiroz"/USP

\author{
Nucci, Tânia Aparecida de \\ Macronutrientes em kiwi cultivares Bruno e Monty: teores, sintomas de carência e \\ exportação pelos frutos / Tânia Aparecida de Nucci. - - Piracicaba , 1996. \\ 95p. : il. \\ Dissertaçāo (mestrado) - Escola Superior de Agricultura Luiz de Queiroz, 1996. \\ Bibliografia. \\ 1. Kiwi - Nutrição 2. Macronutriente em Kiwi l. Título
}

CDD 634.7 


\title{
MACRONUTRIENTES EM KIWI CULTIVARES BRUNO E MONTY: TEORES, SINTOMAS DE CARÊNCIA E EXPORTAÇÃO PELOS FRUTOS
}

\author{
TÂNIA APARECIDA DE NUCCI
}

Aprovada em: 13/09/1996

Comissãa Julgadora:

Prof. Dr. Francisco Antonio Monteiro

ESALQ/USP

Prof. Dr. Quirino Augusto de Camargo Carmello ESALQ/USP

Prof. Dr. Salim Simão

ESALQ/USP

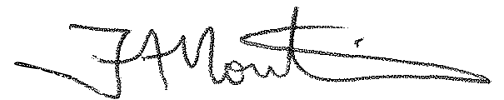

Prof. Dr. FRANCISCO ANTONIO MONTEIRO 
AO SENHOR BUDA MAITREYA OFEREÇO E DEDICO 


\section{AGRADECIMENTOS}

Ao Prof. Dr. Francisco Antonio Monteiro, pela orientação segura, disposição e amizade dedicados à nossa pessoa;

Ao Prof. Dr. Henrique Paulo Haag "in memorian" pelo constante apoio e incentivo que manifestava;

Ao Prof. Dr. Quirino Augusto de Camargo Carmello pela atenção e sugestões ao trabalho;

Ao Prof. Dr. Geraldo Victorino França pela atenção dedicada à nossa pessoa;

Aos docentes da Escola Superior de Agricultura "Luiz de Queiroz"USP, pelos cursos oferecidos;

Ao Pesq. Cient. Dr. Renato Ferraz de Arruda Veiga pelo incentivo e facilidades oferecidas;

Às Pesq. Cient. Dr. ${ }^{a}$ Ana Maria Futino e Dr. ${ }^{a}$ Gláucia Ambrosano pelo apoio nas análises estatísticas;

Às Pesq. Cient. Dr. ${ }^{a}$ Celi Teixeira Feitosa e Dr. ${ }^{a}$ Sandra dos Santos Sevá Nogueira pela fraternidade sempre expressada e colaboração ;

À Sr. ${ }^{\text {a }}$ Miriam Aparecida Bonatto Pissolatto pelo auxílio na digitação;

À Sr. ${ }^{a}$ Patricia Helena F. G. Caruso de Campos, pelo auxílio na preparação das tabelas;

Ao Sr. Roberto Mituo Miazaki, pelo acesso à sua propriedade agrícola;

Ao Sr. Ricardo de Souza Oliveira pelo auxílio na impressão deste trabalho;

Aos Laboratoristas Fernando Éder Ré, Nivanda Maria de Moura, Mirtes Ventura Sesso, Lurdes Ap. Dário de Gonzalez, Ednéia Cristina S. Mondoni e Lúcia H. S. Pavan Forti, pela colaboração na execução de análises químicas de solo e de plantas;

À equipe de Laboratório de Análises de Plantas do Instituto Agronômico de Campinas, pela execução de parte das análises de plantas; 
À Bibl. Kátia Maria de Andrade Ferraz, pela ajuda nas referências bibliográficas;

À Escola Superior de Agricultura "Luiz de Queiroz" pelo uso da infra-estrutura na fase experimental e pela oportunidade de aprendizado;

Ao Instituto Agronômico de Campinas pela oportunidade e facilidades oferecidas;

Ao Conselho Nacional de Desenvolvimento Científico e Tecnológico (CNPq) pela concessão de bolsa de estudos;

Aos colegas Édila Von Pinho, Conceição R. Costa, Maria de Fátima Scaf e Ismael Viégas, sempre solícitos na troca de informações;

A todos que, de alguma forma, colaboraram para a realização deste trabalho de pesquisa. 


\section{SUMÁRIO}

Página

RESUMO

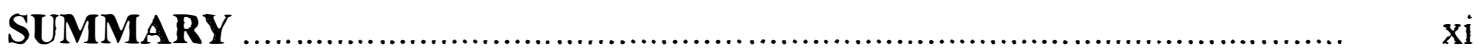

1. INTRODUÇÃO

2. REVISÃO DE LITERATURA …….............................................................

2.1 Generalidades sobre a espécie ..........................................................

2.2. Generalidades sobre o cultivo

2.3. Nutrição mineral do kiwi ..................................................................... 10

2.3.1. Nutrição mineral ....................................................................... 10

2.3.2. Teores de nutrientes............................................................. 12

2.3.3. Adubações em kiwi........................................................................ 18

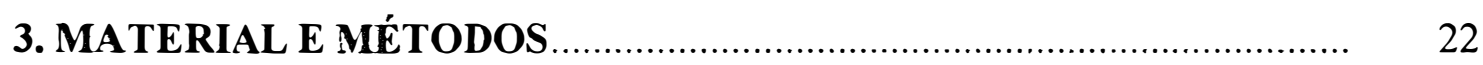

3.1. Experimentos em casa-de-vegetação ……………………………....... 22

3.1.1. Condições de instalação e condução dos experimentos ............... 22

3.1.2. Tratamentos e delineamento experimental ............................... 24

3.1.3. Coleta do material vegetal......................................................... 24

3.1.4. Análise estatística ................................................................... 25

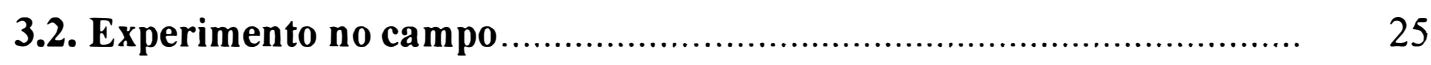

3.2.1. Condições de instalação e condução do experimento.................. 25

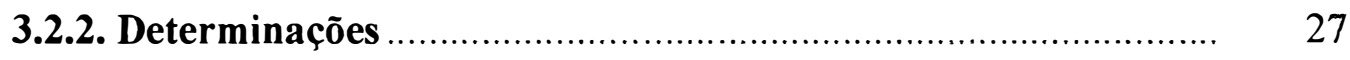

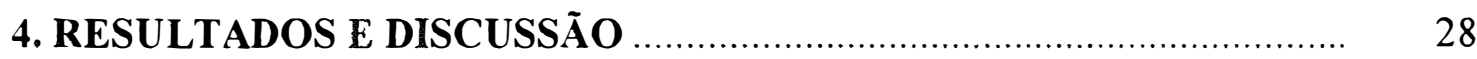

4.1. Experimentos em casa-de-vegetação ………………………………...... 28

4.1.1. Kiwi cultivar Bruno ............................................................... 28

4.1.1.1. Concentração de macronutrientes no tecido vegetal .... 28

4.1.1.1.1. Concentração de nitrogênio ............................. 32

4.1.1.1.2. Concentração de fósforo …………………..... 34

4.1.1.1.3. Concentração de potássio ............................... 36

4.1.1.1.4. Concentração de cálcio .................................. 39

4.1.1.1.5. Concentração de magnésio ………………..... 40

4.1.1.1.6. Concentração de enxofre ............................... 41 
4.1.2. Kiwi cultivar Monty .............................................................

4.1.2.1. Concentração de macronutrientes no tecido vegetal.... 43

4.1.2.1.1. Concentração de nitrogênio ............................ 47

4.1.2.1.2. Concentração de fósforo ………………….... 48

4.1.2.1.3. Concentração de potássio................................. 51

4.1.2.1.4. Concentração de cálcio …………………….. 52

4.1.2.1.5. Concentração de magnésio …………………. 55

4.1.2.1.6. Concentração de enxofre …………………... 57

4.1.3. Concentraçōes em plantas normais e em plantas com

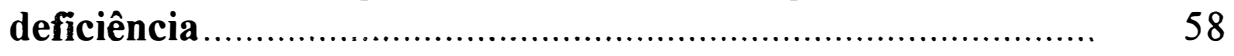

4.1.4. Sintomatologia das deficiências................................................ 59

4.1.4.1. Nitrogênio ................................................................ 59

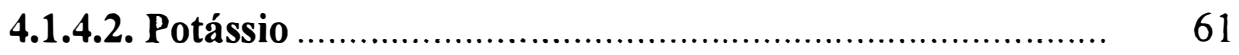

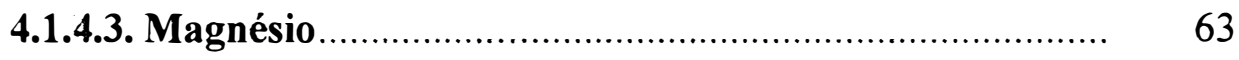

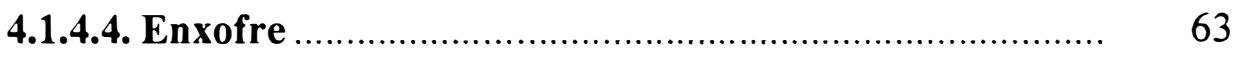

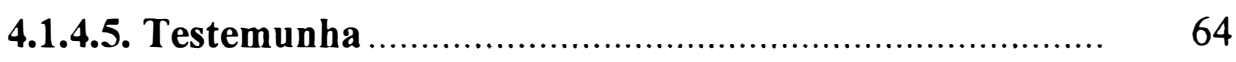

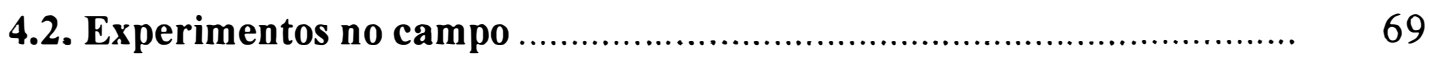

4.2.1. Evolução do peso do material seco dos frutos .............................. 69

4.2.2. Evolução do comportamento dos macronutrientes …………….. $\quad 70$

4.2.2.1. Nitrogênio ................................................................. 70

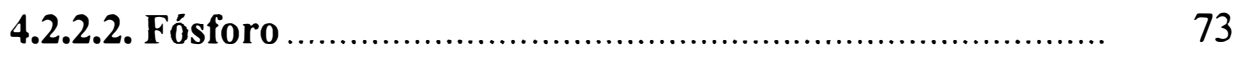

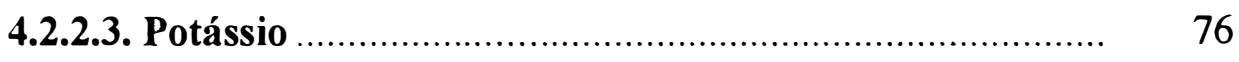

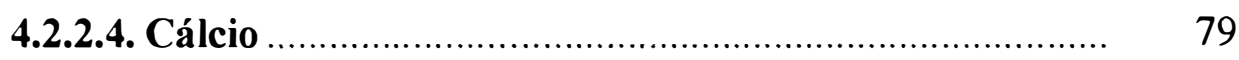

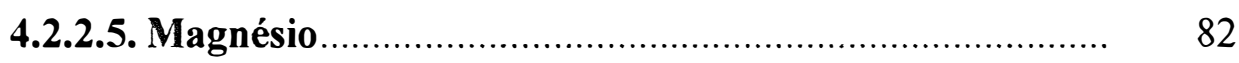

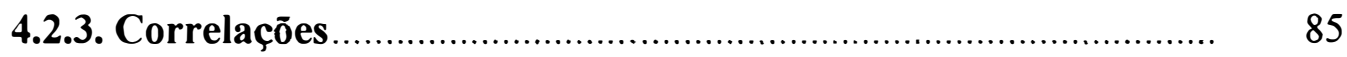

4.2.3.1. Teores de nutrientes na folha amostrada e peso

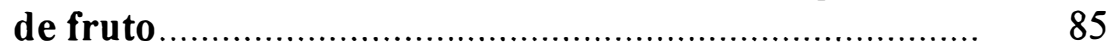

4.2.3.2. Teores de nutrientes na folha amostrada e teores de nutrientes no fruto .................................................. 86

4.2.3.3. Teores de nutrientes na folha amostrada $e$ extração de nutrientes pelo fruto.................................... 88

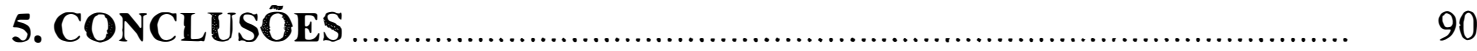

REFERÊNCIAS BIBLIOGRÁFICAS ………...................................... 92 


\title{
MACRONUTRIENTES EM KIWI CULTIVARES BRUNO E MONTY: TEORES, SINTOMAS DE CARÊNCIA E EXPORTAÇÃO PELOS FRUTOS
}

\author{
Autor: TÂNIA APARECIDA DE NUCCI \\ Orientador: PROF. Dr. FRANCISCO ANTONIO MONTEIRO
}

\section{RESUMO}

O presente trabalho teve como objetivo obter em casa-de-vegetação, o quadro sintomatológico das carências nutricionais em N, P, K, Ca, Mg e S, bem como os teores desses nutrientes no tecido vegetal e estudar, em experimento de campo, a exportação de macronutrientes por frutos de kiwi [Actinidia deliciosa (A. Chev.) C. F. Liang et A.R. Ferguson var. deliciosa] cultivares Bruno e Monty.

Para isso, dois experimentos com os cultivares Bruno e Monty foram conduzidos na casa-de-vegetação, localizada no Departamento de Química (Nutrição Mineral de Plantas), da Escola Superior de Agricultura "Luiz de Queiroz", em Piracicaba, Estado de São Paulo. Os experimentos em vasos tiveram oito tratamentos, distribuídos em blocos ao acaso, com quatro repetições. 
Os tratamentos foram os seguintes: completo, omissão de nitrogênio, omissão de fósforo, omissão de potássio, omissão de cálcio, omissão de magnésio, omissão de enxofre, e testemunha. Em todos os tratamentos foram incluídos os micronutrientes boro, cloro, cobre, ferro, manganês, molibdênio e zinco. As plantas foram colhidas quando se evidenciaram os sintomas de carência, e foram divididas em folhas novas (aquelas da metade superior da planta), folhas velhas (aquelas da metade inferior da planta), ramos, "caule" (correspondente à estaca) e raizes. As plantas mostraram sintomas visíveis de deficiência de nitrogênio, potássio, enxofre, e magnésio, quando as concentrações desses macronutrientes foram bem baixas no tecido vegetal. Não foram identificados sintomas visíveis das deficiências de fósforo e de cálcio.

A parte de campo foi conduzida em um pomar, com dez anos de idade, instalado na propriedade Miazaki, bairro Votorantim, município de Ibiúna, Estado de São Paulo, com os cultivares Bruno e Monty. O solo da área foi classificado como Latossolo Vermelho Amarelo fase rasa. As amostragens de cada planta foram realizadas quinzenalmente, totalizando doze épocas de amostragem para o cultivar Bruno e treze para o cultivar Monty.

Nas amostragens foram colhidos, a partir do início da frutificação, frutos e folhas de ramos frutíferos, que foram analisados quanto à sua composição de macronutrientes. Foram traçadas as curvas de teor dos macronutrientes nas folhas e frutos e de extração pelos frutos, nas épocas amostradas. Correlacionaram-se também os resultados dos teores de macronutrientes na folha amostrada com os teores de nutriente no fruto e a extração de nutriente pelo fruto, para cada cultivar. 
Os resultados evidenciaram que a concentração e a extração de nitrogênio pelos frutos do cultivar Monty foram mais elevadas que as dos frutos do cultivar Bruno, enquanto que as de fósforo, potássio, cálcio e magnésio foram similares nesses dois cultivares. Os teores desses macronutrientes foram menores quanto mais desenvolvido estava o fruto. A extração de nutrientes pelos frutos em ambos os cultivares obedeceu a ordem: $\mathrm{K}>\mathrm{N}>\mathrm{P}>\mathrm{Ca}>\mathrm{Mg}$. 


\title{
NUTRIENT REMOVAL BY THE FRUITS AND \\ MACRONUTRIENT CONCENTRATIONS AND \\ DEFICIENCY SYMPTOMS IN THE BRUNO AND \\ MONTY KIWI CULTIVARS
}

\author{
Author: TÂNIA APARECIDA DE NUCCI \\ Adviser: PROF. Dr. FRANCISCO ANTONIO MONTEIRO
}

SUMMARY

This research had as objective to obtain the symptoms of $\mathrm{N}, \mathrm{P}, \mathrm{K}, \mathrm{Ca}$, $\mathrm{Mg}$ and S deficiency and the related nutrient concentrations in the plant tissue, as well as to study these nutrient removals by the fruits of kiwi [Actinidia deliciosa (A. Chev.) C.F. Liang et A.R. Ferguson var. deliciosa], Bruno and Monty cultivars.

Two experiments were carried out with the two kiwi cultivars in a greenhouse at the Chemistry Department (Plant Mineral Nutrition Area), at the College of Agriculture "Luiz de Queiroz", in Piracicaba, State of São Paulo. These experiments had eight treatments each and were assigned in complete randomized block design, with four replications.

The treatments were: complete; omission of $\mathrm{N}$; omission of $\mathrm{P}$; omission of $\mathrm{K}$; omission of $\mathrm{Ca}$; omission of $\mathrm{Mg}$; omission of $\mathrm{S}$ and control. All treatments had the micronutrients $\mathrm{B}, \mathrm{Cl}, \mathrm{Cu}, \mathrm{Fe}, \mathrm{Mn}, \mathrm{Mo}$ and $\mathrm{Zn}$. Plants were 
harvested when visual symptoms had appeared and were separated in young leaves, old leaves, small branches, stalk and roots. Deficiency symptoms were observed for N, K, $\mathrm{Mg}$ and $\mathrm{S}$ when plant tissue concentrations were low for these nutrients. Phosphorus and calcium deficiency symptoms did not appear.

A field experiment with the Bruno and Monty cultivars was carried out in a ten-years old orchard, at Miazaki Farm, at Votorantim District, in Ibiúna, State of São Paulo. The soil was classified as a Red-Yellow Latosol shallow phase. Samples from the plants were taken each two weeks, and 12 sampling times were performed for Bruno and 13 for Monty cultivar.

The nearest leaves to the fruits and the fruits were picked up each sampling time. In these plant materials $\mathrm{N}, \mathrm{P}, \mathrm{K}, \mathrm{Ca}$ and $\mathrm{Mg}$ were determined. Curves for nutrient concentrations in the leaves and fruits and for nutrient removal by fruits in those sampling times were drawn. Correlations were studied between leaf nutrient concentration and fruit nutrient removal, for each kiwi cultivar.

Nitrogen concentration in the fruits and removal by the fruits were higher in the Monty than in the Bruno cultivars, whereas those for $\mathrm{P}, \mathrm{K}, \mathrm{Ca}$ and $\mathrm{Mg}$ were similar in the two cultivars. Macronutrient concentrations lowered as the development of the fruits progressed. Nutrient removal by the fruits followed the order: $\mathrm{K}>\mathrm{N}>\mathrm{P}>\mathrm{Ca}>\mathrm{Mg}$. 


\section{INTRODUÇÃO}

O kiwi, Actinidia deliciosa (A.Chev.) C.F. Liang et A.R.Ferguson var. deliciosa, previamente classificado como Actinidia chinensis Planch., é uma frutífera sarmentosa originária da China, que ao ser introduzida na Nova Zelândia foi submetida a um intenso trabalho de melhoramento e de mercado, sendo hoje cultivada em diversos países. Como possui alto valor nutritivo, principalmente em vitamina $\mathrm{C}$, sais minerais e aminoácidos e um sabor de fácil aceitação por crianças, aliados à sua capacidade de se conservar por períodos de armazenamento relativamente longos ao natural, tem se tornado popular nas últimas décadas na Nova Zelândia, Austrália, França, Estados Unidos, Japão e Chile.

No Brasil, ele foi introduzido na década de 70 , mas somente nos últimos anos o seu cultivo vem tendo franca expansão, tendo encontrado clima favorável nos estados do Sul do país (Santa Catarina, Rio Grande do Sul, Paraná e São Paulo), além de Minas Gerais e Espírito Santo. Devido ao seu alto preço, inicialmente, foi escolhido por produtores como nova opção de cultura nas terras altamente valorizadas do cinturão verde da cidade de São Paulo. Os plantios comerciais mais antigos no Estado de São Paulo possuem de cerca de doze anos, porém a maior parte possui menos de cinco anos 
de plantio, não tendo ainda as plantas atingido idade de plena produção, motivo pelo qual a produção paulista é ainda incipiente. O interesse por essa cultura tem gerado a necessidade de informações para seu cultivo em nossas condições, as quais existem apenas na literatura internacional. Um aspecto que demanda estudos é o nutricional, visando adequar as adubações necessárias para os nossos solos, nas diversas fases de crescimento e de produção dessa cultura.

Neste estudo, os objetivos foram: obter, em casa de vegetação, o quadro sintomatológico das carências nutricionais em N, P, K, Ca, $\mathrm{Mg}$ e S, bem como os teores desses nutrientes no tecido vegetal, e estudar, em condições de campo, a exportação de macronutrientes por frutos de kiwi. 


\section{REVISÃO DE LITERATURA}

\subsection{Generalidades sobre a espécie}

O kiwi é uma frutifera jả largamente cultivada em escala comercial em diversos países. É originária da China, da região do vale do Rio Yang-Tze, mas foi na Nova Zelândia que, após lá ser introduzida, recebeu o trabalho de melhoramento genético além de um bom trabalho de mercado. É também conhecido por outros nomes como: Yang-Tao (China), Chinese gooseberry (Inglaterra) e Groseille de Chine (França). O nome kiwi, como foi chamada na Nova Zelândia, lembra uma ave nativa daquele país.

No Brasil, tem sido incrementada sua importação de países como Nova Zelândia, França e Chile, sendo a produção brasileira ainda incipiente, devido ao fato das plantas serem muito jovens, porém como sua área de cultivo vem crescendo, é de se esperar que venha a ter maior importância econômica nos próximos anos.

Devido ao seu alto valor unitário, sua rentabilidade e a alta exigência em mão de obra qualificada, ele tem-se viabilizado como cultura alternativa para as pequenas propriedades no Estado de São Paulo, apesar de seu alto custo de instalação. Seu cultivo também vem sendo incrementado nos Estados do Rio Grande do Sul, Santa 
Catarina, Paraná, Minas Gerais e nas regiões serranas do Espírito Santo. Ressalta-se, no entanto, que essa é uma cultura bastante artesanal, exigindo muita qualificação e dedicação por parte do produtor.

A comercialização do kiwi é muito facilitada pelo fato de seus frutos manterem o seu sabor, mesmo quando conservados por longos períodos, além de apresentarem um alto valor alimentício. Trata-se de um fruto rico em vitamina C, cálcio, ferro, fósforo e aminoácidos, o que o torna uma boa opção alimentícia à população, além de possuir um sabor agradável, de fácil aceitação, inclusive pelas crianças. Possui além disso uma enzima, a actinidina, que tem a propriedade de amaciar as carnes.

Geograficamente, o gênero Actinidia tem uma vasta distribuição pela Ásia Oriental, que abrange desde a ilha de Sachalin $\left(50^{\circ}\right.$ latitude Norte) até a ilha de Java ( $8^{\circ}$ latitude Sul $)$ e desde o Himalaia através da China, até a Costa Oriental do Japão (FENAROLI, 1982). Seu cultivo foi adaptado em paises de diversos continentes, tais como Nova Zelândia, Austrália, França, Itália, Estados Unidos, Chile, Brasil e África do Sul.

A espécie cultivada comercialmente em grande escala é Actinidia deliciosa (A. Chev.) C F. Liang et A. R. Ferguson var. deliciosa, da família Actinidiaceae, e que foi anteriormente classificada como Actinidia chinensis Planch (FERGUSON, 1984). As plantas dessa espécie, assim como o gênero Actinidia em geral, caracterizam-se por serem frutiferas arbustivas, com folhas simples e caducas, flores dióicas e ocorrência de plantas estaminiferas mais freqüentes do que as 
pistilíferas. São encontradas crescendo ao longo das margens dos rios asiáticos e nas margens sombreadas dos bosques, com seus ramos entrelaçando-se nas plantas hospedeiras.

Os cultivares existentes surgiram a partir de plantas selecionadas na Nova Zelândia por viveiristas e técnicos, que visavam principalmente maior tamanho do fruto. Hoje outros países vêm desenvolvendo novos cultivares, notadamente buscando menor exigência em horas de frio. No Brasil, os cultivares mais conhecidos são, 'Bruno', 'Monty', 'Hayward', 'Abbot', 'Allison', todos eles femininos e os cultivares 'Matua' e 'Tomuri' usados como polinizadores. No Estado de São Paulo os cultivares Bruno e Monty são os mais cultivados. Recentemente outros cultivares de origem japonesa, com polpa amarela vêm sendo introduzidos no Estado de São Paulo.

'Bruno' é um cultivar medianamente vigoroso, com frutos de tamanho médio, cilíndricos e alongados e dificilmente podem ser confundidos com os de outros cultivares disponíveis no mercado. São cobertos por pelos densos, curtos e cheios de cerdas. Em paises onde o fruto é industrializado, os processadores preferem este cultivar por causa do grande número de fatias uniformes que podem ser obtidas de cada fruto alongado. É um cultivar não muito exigente em horas de frio, bem adaptado ao Estado de São Paulo, nas regiões de Cotia, Ibiúna e São Roque.

'Monty' é um cultivar um pouco mais tardio do que o 'Bruno' e também não muito exigente em horas de frio. Devido ao fato de formar numerosos frutos, muitas vezes é necessário o desbaste dos mesmos, para que sejam obtidos frutos de bom tamanho. É um dos únicos cultivares que apresenta flor composta, ou seja, mais de 
uma flor por inflorescência, o que é comum em cultivares polinizadores, aumentando o seu potencial produtivo (SCHUCK, 1992). Os frutos são oblongos e cobertos por uma densa camada de pelos longos e de tamanho médio para grande. Também encontra-se adaptado às regiões paulistas anteriormente mencionadas.

\subsection{Generalidades sobre o cultivo}

Sob condições edafoclimáticas adequadas, as plantas do kiwi são produtivas por mais de quarenta anos, crescem vigorosamente durante o verão e são dormentes no inverno. Nas condições do Estado de São Paulo são colhidas nos meses de abril e maio.

Na sua região de origem, encontra um alto grau de umidade no período de verão, devido às freqüentes chuvas e à vegetação abundante, com precipitação média anual de 1000 a $2000^{\circ} \mathrm{mm}$, temperatura branda no verão, sendo a temperatura média de julho de $27^{\circ} \mathrm{C}$ e a temperatura média anual de $15^{\circ} \mathrm{C}$. A intensidade luminosa é limitada em parte pela sombra das plantas que fornecem suporte, sendo a radiação global em torno de $100-140 \mathrm{kcal} \mathrm{cm}^{-2} \mathrm{ano}^{-1}$. No inverno, a temperatura é baixa, com a média de $5^{\circ} \mathrm{C}$ em janeiro e as chuvas são escassas. O clima é classificado como $\mathrm{CW}$ : clima temperado com inverno seco. Os solos da região têm alto teor de matéria orgânica e pH variável de neutro a ligeiramente ácido. É fácil depreender disso que, quanto à temperatura para uma produção de frutos bem sucedida, o kiwi necessita de um inverno frio, para assegurar a abertura de botões na primavera e subsequente florescimento. 
Para ocorrer a dormência e a emergência dos botões florais é preciso que ocorram de 500 a 700 horas de frio abaixo de $7,2^{\circ} \mathrm{C}$, dependendo do cultivar.

Quanto à necessidade de água, as plantas de kiwi não toleram a seca durante a primavera, verão e outono, épocas do seu crescimento ativo. Necessitam de no mínimo $100 \mathrm{~mm}$ de água por mês e, caso a precipitação pluvial seja insuficiente, há necessidade de irrigação (FENAROLI, 1982). Devido ao fato de seus ramos jovens serem muito suculentos e, portanto, muito sujeitos a quebras, tem sido ressaltada a necessidade do uso de quebra-ventos para a proteção do kiwi durante seu crescimento.

Quanto à necessidade de luz, GRANT \& RYUGO (1984), estudando o sombreamento em plantas de kiwi com 6 anos de idade, constataram que os frutos conduzidos sobre a copa foliar principal, ou seja, expostos à luz, foram significativamente maiores do que aqueles provenientes de ramos sombreados.

O kiwi cresce em vários tipos de solo, desde que sejam bem drenados até uma profundidade de no mínimo um metro, pois é uma planta muito sensível a solos encharcados. Cresce em pH entre 5,0 e 8,0 sendo que a faixa entre 5,5 e 6,5 proporciona seu melhor desenvolvimento.

Sua propagação pode ser feita de diversos modos. Uma delas utiliza sementes, quando as plantas são destinadas a porta-enxerto, e após a realização de uma seleção durante um ano em viveiro. A outra é por estacas, a qual é mais utilizada para as variedades melhoradas, sendo que essas estacas podem ser de ramos semi herbáceos, de ramos lenhosos e de raizes. As de ramos lenhosos são retiradas no inverno e devem ser mergulhadas em auxinas rizógenas para provocar um bom enraizamento. 
Quando se deseja a rápida propagação das plantas também utiliza-se a enxertia em cunha, em triângulo e em garfo inglês (ZUCCHERELLI \& ZUCCHERELLI, 1981). Finalmente, existe a possibilidade do uso da cultura de tecidos que, segundo MONETTE (1986), é um bom método para a manutenção dos genótipos desejáveis.

Um cuidado indispensável nessa cultura é a poda, para controlar o desenvolvimento da planta, pois seu vigor promove o entrelaçamento e o estrangulamento dos ramos num curto período de tempo. A condução é realizada elevando um só fuste principal e suprimindo-se os outros, antes que se tornem muito desenvolvidos. Do fuste ou tronco principal, após ter atingido $1,8 \mathrm{~m}$ de altura, selecionam-se 2 ou 3 ramos permanentes, conduzindo-os horizontalmente, como cordão, deixando-se os ramos à esquerda e à direita, alternadamente, ao longo dos fios da espaldeira. Sobre estes ramos permanentes se desenvolvem os ramos férteis, os quais devem ser mantidos na distância de 0,3 a 0,4 m entre si, devendo ser mantidos por dois ou três anos, antes de serem substituídos pela poda de renovação. Além de controlar o desenvolvimento, a poda mantém um equilíbrio harmônico entre os ramos vegetativos permanentes e os férteis, facilitando a polinização e as práticas culturais.

A poda é feita em duas épocas: durante o verão, no curso da estação vegetativa, para reduzir o excesso de ramificações secundárias e o conseqüente sombreamento dos ramos frutíferos e, durante o inverno, para eliminar os ramos férteis, sendo praticada quando a planta está em estado de repouso, isto é, depois da colheita e da queda das folhas e antes da rebrota vegetativa primaveril. Eliminam-se os ramos ladrões (os que crescem verticalmente) e encurtam-se para 7-8 gemas os ramos de produção. 
Por ser uma planta dióica, é importantíssima a distribuição racional de plantas estaminíferas e pistilíferas e que ambas tenham sua época de florescimento coincidentes. $\mathrm{O}$ vento $\mathrm{e}$ os insetos são vitais para assegurar a polinização. $\mathrm{O}$ espaçamento entre linhas deve ser em função da fertilidade do terreno, variando entre 4 e $5 \mathrm{~m}$. Dentro das linhas, o espaçamento varia segundo o vigor de cada cultivar, desde $6 \mathrm{~m}$ para o cultivar Hayward até 9 ou $10 \mathrm{~m}$ para o 'Monty' (POVES, 1982).

O potencial produtivo e a entrada precoce em produção de uma plantação de kiwi dependem do tipo de material de viveiro utilizado, do cultivar, da metodologia de poda, do sistema de cultivo, do ambiente edafoclimático e da técnica cultural empregada. O kiwi entra em produção do segundo ao quarto ano depois de instalado no campo, com diferenças significativas entre os diversos cultivares. Com a enxertia efetuada em um bom "cavalo" de 2 anos, já no segundo e terceiro ano, depois de instaladas, pode-se obter as primeiras produções significativas com o 'Bruno', 'Abbot' e 'Monty'; este último pode atingir uma boa produção por ocasião do quinto ao sexto anos. O 'Hayward' é o mais tardio para entrar em produção, as plantas de estação devem entrar em produção no quarto ou quinto ano, embora plantas fortes, conduzidas com técnicas racionais, possam dar a primeira produção significativa no terceiro ou quarto ano de plantio.

Uma planta bem conduzida pode produzir cerca de 500 a 800 frutos comercializáveis, por estação, durante vários anos. Até o momento não se determinou o ponto ideal de colheita de frutos para as condições paulistas, sendo que na Austrália o padrão minimo de maturação aceito é de $6,2 \%$ de sólidos solúveis totais, medidos por 
refratômetro, uma hora após a colheita dos frutos, pois o kiwi inicia a conversão do amido armazenado em açúcares, imediatamente após o processo de armazenamento ser estabelecido. No armazenamento do kiwi, é importantíssima a ausência de etileno, motivo pelo qual não devem ser colocadas outras frutas em conjunto, como a maçã, por exemplo. Frutos danificados ou maduros também não devem ser colocados em conjunto, pois podem causar amadurecimento prematuro de todos os frutos armazenados (Bagshaw \& Watson ${ }^{(1)}$, 1984 e ZUCCHERELLI \& ZUCCHERELLI, 1981). O pronto resfriamento dos frutos após a colheita tem sido recomendado, para prevenir podridões dos frutos causadas por Alternaria alternata e Botrytis cinerea.

\subsection{Nutrição mineral do kiwi}

\subsubsection{Nutrição mineral}

Embora todas as plantas necessitem os mesmos minerais para completar seu ciclo de vida, as quantidades e os balanços necessários para crescimento ótimo e obtenção de altas produções variam muito entre as espécies (SHEAR \& FAUST, 1980).

Na produção de frutas, talvez mais do que em qualquer outro grupo de plantas econômicas, o desequilíbrio de nutrientes pode manifestar-se em características da qualidade dos frutos de plantas (SHEAR \& FAUST,1980).

${ }^{(1)}$ BAGSHAW, J.S. \& WATSON, B.J. - (Department of Primary Industries near North Coast, Australia) Kiwifruit- District Crop Summary - Brisbane to Gympie: correspondência recebida. 1984 
Os sintomas visuais são muito úteis na identificação das desordens nutricionais, porém, para diagnosticar-se o desbalanço responsável pela ocorrência de um sintoma específico, é freqüentemente necessário um conhecimento da concentração de nutrientes de uma ou mais partes da planta. Muitos fatores, além dos nuricionais podem ser responsáveis pela redução no crescimento da planta ou pela indução de sintomas, que podem ser confundidos com aqueles dos excessos ou deficiências de nurrientes (Woodbridge ${ }^{(2)}, 1976$ citado por SHEAR \& FAUST, 1980). Seca, calor, frio, injúria mecânica, insetos, nematóides, doenças patogênicas, herbicidas e pesticidas podem produzir sintomas quase similares àqueles de má nutrição (SHEAR \& FAUST, 1980). Dos muitos fatores que afetam a composição nutricional das plantas, o local do pomar, o cultivar, o porta enxerto e a época de amostragem são talvez os mais comuns (TAGLIAVINI et al., 1992).

A diagnose foliar é usada para identificar as causas de uma performance sub ótima da planta, no diagnóstico de deficiências incipientes e nos desequilíbrios nutricionais (TAGLIAVINI et al., 1992).

As desordens nutricionais têm ocorrido em pomares de kiwi na Nova Zelândia, conforme ASHER et al. (1984), tais desordens têm resultado em consideráveis perdas na produção de kiwi e também prejudicado a qualidade de armazenamento dos frutos (SMITH et al., 1987a).

\footnotetext{
${ }^{(2)}$ WOODBRIDGE,C.G. Nutritional disorders that resemble virus disorders. In: . . . . - - Virus diseases and noninfections disorders of stone fruits in North America. Washington, USDA, 1976. p.316-46. (USDA. Agricultural Handbook, 437).
} 


\subsubsection{Teores de nutrientes}

$\mathrm{Na}$ Itália LALATTA (1985) apresentou valores de referência do nível nutricional da folha de kiwi, considerando a sexta ou a sétima folha, colhida sem o pecíolo de: nitrogênio: 2,20 a 2,60 dag kg ${ }^{-1}$; fósforo: 0,18 a $0,25 \mathrm{dag} \mathrm{kg}^{-1}$; potássio: 1,60 a 2,00 dag $\mathrm{kg}^{-1}$; cálcio: 2,20 a 2,80 dag kg-1 e magnésio: 0,35 a $0,70 \mathrm{dag} \mathrm{kg}^{-1}$.

SALE (1985) apontou os níveis de nutrientes desejáveis em kiwi, recomendando sua utilização para a monitoração anual na Nova Zelândia, em fevereiro ou março, com amostras de no mínimo 24 folhas com os pecíolos, coletando a quarta folha após o fruto ou a primeira folha madura de um ramo não frutífero.

BATTELLI \& RENZI (1990), em um levantamento nutricional em 48 pomares de kiwi cultivar Hayward ao norte da Itália, não encontraram relação entre a composição foliar e a análise do solo. Para esses autores, também foram baixas as correlações entre os teores de nutrientes nas folhas, na mesma estação de crescimento, sendo encontrada maior estabilidade foliar na época da colheita. Esses autores, com base em lâminas da segunda e terceira folhas acima do último fruto, colhidas na época da colheita e no cálculo da remoção ocorrida, estabeleceram um guia para os níveis de nutrientes no cultivar Hayward.

Ainda BATTELLI \& RENZI (1990) encontraram a seguinte composição química nos frutos, em relação à matéria seca: nitrogênio - $1,12 \mathrm{dag} \mathrm{kg}^{-1}$; fósforo $-0,23$ dag $\mathrm{kg}^{-1}$; potássio - 2,46 dag $\mathrm{kg}^{-1}$; cálcio - 0,18 dag $\mathrm{kg}^{-1}$; magnésio - 0,09 dag $\mathrm{kg}^{-1}$; ferro $19 \mathrm{mg} \mathrm{kg}^{-1}$; cobre $-8 \mathrm{mg} \mathrm{kg}^{-1}$; manganês $-5 \mathrm{mg} \mathrm{kg}^{-1}$ e zinco $-5 \mathrm{mg} \mathrm{kg}$. 
LIONAKIS \& SCHWABE (1985) descreveram os sintomas de defíciência de nitrogênio, fósforo, potássio, e magnésio em plantas de kiwi do cultivar Bruno. Os autores observaram o amarelecimento das folhas, quando induziram a deficiência de nitrogênio, coloração verde escura das folhas na carência de fósforo, lesões típicas na insuficiência de potássio, e semelhança às outras espécies quanto ao magnésio.

CRESSWELL (1989), ao monitorar a composição de nutrientes nas folhas de plantas maduras de kiwi dos cultivares Hayward e Bruno, em Nova Gales do Sul, da Austrália, na primeira folha após o fruto, observou que dentro da estação de crescimento, as concentrações de $\mathrm{N}\left(5,07-2,04 \mathrm{dag} \mathrm{kg}^{-1}\right), \mathrm{P}\left(1,0-0,44 \mathrm{dag} \mathrm{kg}^{-1}\right), \mathrm{K}(3,29-$ $\left.1,95 \mathrm{dag} \mathrm{kg}^{-1}\right)$ e de $\mathrm{Zn}\left(36-19 \mathrm{mg} \mathrm{kg}^{-1}\right)$ decresceram em geral, enquanto que as concentrações de $\mathrm{Ca}\left(1,41-4,21 \mathrm{dag} \mathrm{kg}^{-1}\right), \quad \mathrm{Mg}\left(0,28-0,50 \mathrm{dag} \mathrm{kg}^{-1}\right)$ e Mn (151$275 \mathrm{mg} \mathrm{kg}^{-1}$ ) aumentaram. Esse autor verificou que a composição foliar é relativamente estável em fevereiro na região estudada, propondo que essa técnica fosse adotada como padrão, para a análise foliar nessa região.

SMITH et al. (1987b), estudando a acumulação de macro e micronutrientes pelas folhas de kiwi cultivar Hayward, durante duas estações de crescimento, encontraram que as concentrações de nitrogênio, fósforo, cobre e zinco decresceram inicialmente, porém atingiram valores que permaneceram relativamente constantes pelo meio da estação de crescimento. Para cálcio, magnésio, enxofre, boro, manganês e ferro, as concentrações nas folhas também decresceram inicialmente, porém depois aumentaram pelo restante da estação de crescimento. 
GIORGIO et al. (1992), em um estudo na Itália, com quatro pomares de plantas de kiwi cultivar Hayward e comparando as análises de folhas e de pecíolos em quatro épocas, encontraram diferenças na composição de elementos entre as lâminas e os pecíolos, as datas de amostragem e os pomares. Os teores de $\mathrm{N}, \mathrm{K}, \mathrm{Cu}$ e $\mathrm{Zn}$ decresceram durante a estação de crescimento e a absorção de nutrientes foi maior, quando as plantas estavam em solos férteis.

SMITH et al. (1987a) comentaram que as plantas de kiwi de todas as idades, manifestaram deficiência de potássio, porém as plantas de pomares em início de produção (quatro a seis anos), foram as mais afetadas.

CLARK \& SMITH (1987) encontraram que plantas de kiwi com deficiência de magnésio apresentavam concentrações desse nutriente, nas folhas mais jovens expandidas, menores que $0,2 \mathrm{dag} \mathrm{kg}^{-1}$.

FERGUSON (1980), ao estudar o conteúdo de alguns macronutrientes em frutos de kiwi durante seu período de crescimento, observou que o conteúdo de cálcio atingiu seu máximo muito mais cedo que os outros nutrientes (por volta dos 70-80 dias após o florescimento), enquanto os conteúdos de potássio e fósforo continuaram a aumentar no fruto durante toda a estação de crescimento, tendo atingido valores máximos em torno dos 180 dias após o florescimento. Esse autor estudou a distribuição de cátions no fruto maduro, que demonstrou um gradiente marcante no conteúdo de cálcio, que foi mais alto na extremidade inferior do fruto, enquanto o conteúdo de potássio e o de magnésio não mostraram qualquer padrão de distribuição. 
CLARK \& SMITH (1988), ao estudarem as mudanças na concentração, distribuição e quantidade de macro e micronutrientes na pele e na polpa dos frutos de kiwi cultivar Hayward, durante uma estação de crescimento, encontraram que as concentrações de nitrogênio, fósforo, potássio, enxofre, cobre, ferro e zinco na polpa, incluindo as sementes, diminuiram acentuadamente durante as oito primeiras semanas de crescimento, e a partir daí alcançaram valores que se mantiveram relativamente constantes, ou diminuiram gradualmente até a colheita. Já as concentrações de boro, cálcio, magnésio e manganês decresceram acentuadamente com o passar do tempo. Comparando-se com a concentração de nutrientes na pele do fruto durante o período de maturação (23 semanas), as concentrações de nitrogênio, fósforo e potássio na polpa foram geralmente mais altas e as de cálcio, manganês e zinco foram consistentemente mais baixas. A quantidade de todos os nutrientes aumentou através da estação, até um máximo na época da colheita.

KOTZÉ \& VILLIERS (1989) estudaram a absorção e a distribuição de nutrientes em plantas de kiwi cultivar Hayward, na África do Sul, cultivadas em areia e nutridas com solução nutritiva de HOAGLAND. Para esses autores, o peso do material seco total aumentou muito durante a estação de crescimento, desde a quebra de dormência das gemas até cinco meses após, sendo que o maior acréscimo ocorreu nas brotações novas da parte aérea (47\%), enquanto que as raízes tiveram $33 \%$ de acréscimo. A contribuição das raízes para o peso do material seco total decresceu de $60 \%$ durante a dormência para $40 \%$ na época da colheita. Esses autores encontraram indicações de que as reservas de nitrogênio principalmente e em menor proporção as de 
potássio das raízes e casca do tronco teriam um importante papel no desenvolvimento da planta, logo após o rompimento das gemas. Cerca de $50 \%$ do cálcio absorvido pela planta do kiwi foi translocado para suas folhas. As raizes, além de perfazerem $60 \%$ do peso do material seco total da planta durante a dormência, continham $75-85 \%$ do conteúdo total de macronutrientes da planta naquele estádio.

Ainda segundo esses autores, o período ativo de absorção de cálcio, magnésio e fósforo coincidiu razoavelmente com aquele de aumento de produção de material seco, sendo que o cálcio e o magnésio concentraram-se principalmente nas raizes ( $48 \%$ e $63 \%$ respectivamente) e nas folhas ( $38 \%$ e $24 \%$ respectivamente), com menores quantidades em outros órgãos na colheita, enquanto que a maior parte do nitrogênio $(33 \%)$, potássio $(27 \%)$ e fósforo $(23 \%)$ foi consideravelmente encontrada nas folhas e nos frutos. Tanto o nitrogênio como o potássio foram absorvidos até quatro semanas antes da colheita, enquanto o conteúdo de potássio nas folhas decresceu durante as dez semanas precedentes à colheita.

KOTZÉ \& VILLIERS (1989) ainda afirmaram que o fruto era um grande dreno de potássio e que esse nutriente era aparentemente translocado das folhas e possivelmente de outros tecidos para os frutos. Afirmaram também, que devido ao fato do potássio e o nitrogênio serem transportados das folhas para os frutos antes da colheita, uma deficiência poderia ocorrer nas folhas, mesmo quando a planta tenha sido bem suprida com esses nutrientes.

FERGUSON et al. (1987) estudaram as mudanças na concentração dos nutrientes nos frutos durante o crescimento, as quais são apresentadas a seguir: o cálcio, 
em sua maior parte, foi translocado para o fruto durante os primeiros 60 - 70 dias e, após isso houve pequena alteração no conteúdo de cálcio do fruto. A absorção de nitrogênio, magnésio e fósforo ocorreu durante todo o desenvolvimento do fruto porém, o acúmulo desses nutrientes decresceu em relação à sua porcentagem no peso do material seco. Já o potássio acumulou-se segundo o aumento do material seco, com exceção dos dois primeiros meses de crescimento e, do início até o fim do crescimento, a concentração de potássio em função do peso do material seco, desceu cerca de $10 \%$ A queda durante esse periodo nas concentrações de outros macronutrientes foi de $25 \%$ para o fósforo, $36 \%$ para o nitrogênio, $50 \%$ para o magnésio e $65 \%$ para o cálcio.

FERGUSON et al. (1987) estimaram também, que na época da colheita, o total de frutos em uma planta continha cerca de 200 a $300 \mathrm{~g}$ de potássio, uma parte considerável de todo o potássio da planta.

BUWALDA et al. (1990), estudando os efeitos da deficiência de nitrogênio em plantas de kiwi cultivar Hayward, em um campo com várias densidades de plantio $\left(25,0,12,5\right.$ e $8,33 \mathrm{~m}^{2}$ planta $\left.^{-1}\right)$ durante sete anos, quando foram aplicadas quantidades variando de 0 a $200 \mathrm{~kg} \mathrm{ha}^{-1}$ de $\mathrm{N}$, observaram que a quantidade de $\mathrm{N}$ aplicada afetou significativamente as concentrações do nutriente na folha em todos os anos a partir do quarto ano, e que as concentrações médias de $\mathrm{N}$ na folha diminuíram durante o experimento. As concentrações nos frutos variaram significativamente com o nível de $\mathrm{N}$ aplicado, já no quinto ano do experimento. A concentração de nitrogênio nos frutos variou amplamente entre os anos e foi inversamente proporcional ao número 
de frutos por metro quadrado, indicando que após o início da formação dos frutos, o crescimento do número de frutos foi relativamente insensível ao nível de $\mathrm{N}$ na planta. Observaram também, que os efeitos do suprimento de $\mathrm{N}$ sobre as produções de frutos resultaram na maior parte das mudanças no número de frutos por unidade de área de cultivo. Em qualquer ano, as produções máximas de frutos por plantas, em cultivos com alta densidade, foram associadas com as concentrações de $\mathrm{N}$ na folha (20 semanas após rompimento das gemas) de pelo menos $1,8 \mathrm{mmol} \mathrm{g}^{-1}$. Para as plantas em baixa densidade de plantio, respostas significativas não foram registradas até o sétimo ano de experimento, e as produções máximas naquele ano foram associadas com concentrações

de $\mathrm{N}$ na folha de pelo menos $1,4 \mathrm{mmol} \mathrm{g}^{-1}$. Nas duas últimas estações do experimento, uma necrose foliar desenvolveu-se extensivamente nas plantas que receberam menos que a dose máxima de adubação nitrogenada. Essa necrose pareceu ser senescência prematura, resultante da deficiência de nitrogênio.

\subsubsection{Adubações em kiwi}

SALE (1985) recomendou as seguintes adubações para as condições da Nova Zelândia, considerando a produtividade do cultivar Hayward em torno de 25 toneladas por hectare, e considerando as fases jovem e adulta da planta: no plantio ele recomendou a aplicação de $0,5 \mathrm{~kg}$ de farinha de sangue e ossos ou outro fertilizante orgânico, misturando-se bem ao solo para evitar danos às raízes. Para os primeiros dois anos da planta, recomendou a fertilização com adubo nitrogenado individual e 
parceladamente, espalhando-se no primeiro ano $14 \mathrm{~g}$ de $\mathrm{N}$ por 1 a $2 \mathrm{~m}^{2}$, três ou quatro vezes, entre outubro e fevereiro e, no segundo ano, $55 \mathrm{~g}$ de $\mathrm{N}$ distribuídos por 3 ou $5 \mathrm{~m}^{2}$ em setembro, seguidos por três coberturas de $28 \mathrm{~g}$ de $\mathrm{N}$, entre outubro e fevereiro. Para o terceiro ano após o plantio, recomendou que sejam aplicados $115 \mathrm{~kg} \mathrm{ha}^{-1}$ de nitrogênio em setembro, seguidos de $57 \mathrm{~kg} \mathrm{ha}^{-1}$ de nitrogênio em novembro. Para a manutenção das plantas maduras, quando as análises de solo e folhas foram adequadas, recomendou a aplicação de $170 \mathrm{~kg} \mathrm{ha}^{-1}$ de nitrogênio, sendo dois terços em setembro e o restante em novembro. Uma aplicação única de $56 \mathrm{~kg} \mathrm{ha}^{-1}$ do fósforo em agosto ou setembro e, quanto ao potássio, duas ou três coberturas sobre toda área, entre setembro e fevereiro, totalizando $150-200 \mathrm{~kg} \mathrm{ha}^{-1}$. Segundo esse autor, onde for uma das práticas a remoção dos ramos podados do pomar, devem ser aplicadas quantidades maiores de fertilizantes, especialmente de potássio.

MARSH et al. (1991) relataram que doses acima de $250 \mathrm{~kg} \mathrm{ha}^{-1}$ de potássio são recomendadas para plantas produtivas de kiwi na Nova Zelândia.

LALATTA et al. (1990) reportaram que nas maiores áreas de produção da Itália, as doses de macronutrientes aplicadas anualmente por hectare foram aproximadamente: $150-600 \mathrm{~kg} \mathrm{~N}, 150-250 \mathrm{~kg} \mathrm{P}_{2} \mathrm{O}_{5}, 150-300 \mathrm{~kg} \mathrm{~K} \mathrm{O}_{2} \mathrm{O}$, sendo a análise de solo o método mais comum de estimativa da necessidade de fertilizante para o pomar de kiwi. Devido à alta produtividade e rentabilidade (25 a 30 toneladas métricas/ha), os produtores italianos geralmente aplicavam quantidades elevadas de adubos orgânico e mineral. Por meio de um levantamento feito através da análise foliar, os autores concluíram que as aplicações de fertilizantes nos pomares de kiwi eram em geral 
adequadas e algumas vezes excessivas. Embora tenham amostrado plantas masculinas e do cultivar Hayward, os autores aconselharam somente a amostragem de folhas de plantas Hayward.

Numa planta madura de kiwi, a parte permanente, acima do nível do solo, consiste do tronco e dos ramos principais. Os ramos frutíferos são substituídos a cada dois ou três anos e, como a planta é decídua, as folhas e os frutos são perdidos ou removidos todos os anos. Muito da parte aérea da planta é transferida anualmente, sendo que o acúmulo de minerais no fruto é o principal dreno dos recursos da planta.

FERGUSON et al. (1987), analisando plantas do cultivar Hayward com quinze anos de idade, antes da colheita dos frutos, observaram que a estrutura permanente da planta constava de apenas de $30 \%$ do peso material seco da parte aérea. As brotações da estação e as de duas estações anteriores, compreendiam outros $30 \%$ e os frutos, cerca de $25 \%$. Isso representava um quadro estático de uma planta madura num estágio particular da estação, porém, a cada ano, a planta perdia seus frutos e folhas, que representavam juntos, acerca de $40 \%$ do peso seco da parte aérea. Além disso, muitos dos ramos velhos que já frutificaram e também das novas brotações são removidos durante as podas e, isso significa, no conjunto, que cerca de $60 \%$ da parte aérea da planta foi reposta durante a estação.

Observaram também, que ocorreu reposição de tecidos no sistema radicular, onde as raízes finas, realmente ativas na absorção de nutrientes, têm curta duração, sendo substituídas rapidamente. Num pomar de kiwi, os nutrientes são removidos ou por lixiviação ou pela remoção de partes da planta. Apenas para as 
plantas jovens é importante a quantidade de nutrientes imobilizada na estrutura da planta e em plantas adultas, a maior parte dos nutrientes removidos estava nos frutos colhidos.

FERGUSON \& EISEMAN (1983) citaram que a média de produção da Nova Zelândia atinge cerca de 25 toneladas por hectare, o que eqüivale a cerca de 4,5 toneladas de material seco por hectare. Os autores estimaram as quantidades removidas a cada ano por essa cultura, com os seguintes valores aproximados de macronutrientes: nitrogênio $-38 \mathrm{~kg} \mathrm{ha}^{-1}$, fósforo $-5,5 \mathrm{~kg} \mathrm{ha}^{-1}$, cálcio $-7 \mathrm{~kg} \mathrm{ha}^{-1}$, magnésio $-3,5 \mathrm{~kg} \mathrm{ha}^{-1}$ e potássio $-75 \mathrm{~kg} \mathrm{ha}^{-1}$. 


\section{MATERIAL E MÉTODOS}

Os cultivares Bruno e Monty de kiwi (Actinidia deliciosa (A. Chev.) C.F. Liang et A.R. Ferguson var. deliciosa), familia Actinidiaceae, ordem Theales, foram estudados em experimento sob condições controladas e de campo.

\subsection{Experimentos em casa-de-vegetação}

\subsubsection{Condições de instalação e condução dos experimentos}

Dois experimentos foram conduzidos na casa-de-vegetação localizada no Departamento de Química (Nutrição Mineral de Plantas) da Escola Superior de Agricultura Luiz de Queiroz, em Piracicaba, Estado de São Paulo, com os cultivares Bruno e Monty.

A partir de estacas, anteriormente imersas em fitorregulador NAA a 100 $\mathrm{mg} \mathrm{L}^{-1}$, por 24 horas, em agosto do ano anterior, cultivaram-se plantas de kiwi inicialmente enraizadas em areia, em viveiro, no Instituto Agronômico, em Campinas. Após o enraizamento as plantas foram transferidas para os vasos plásticos com cinco 
quilogramas de sílica e, até se adaptarem ao cultivo em vasos, receberam a solução nutritiva completa proposta por SARRUGE (1975) diluída a 1:4. Antes do início dos tratamentos os vasos com sílica sofreram lavagens com água destilada por três dias, para eliminar-se os nutrientes que pudessem estar na sílica.

Tabela 1. Composição das soluções nutritivas de SARRUGE (1975).

\begin{tabular}{|c|c|c|c|c|c|c|c|c|}
\hline \multirow{2}{*}{$\begin{array}{l}\text { Solucões } \\
\text { Estoque }\end{array}$} & & \multicolumn{7}{|c|}{ Tratamento } \\
\hline & & Completo & $-N$ & $-P$ & $-\mathbf{K}$ & $-\mathbf{C a}$ & $-\mathbf{M g}$ & $-S$ \\
\hline & & \multicolumn{7}{|c|}{$m L L^{-1}$} \\
\hline $\mathrm{KH}_{2} \mathrm{PO}_{4}$ & M & 1 & 1 & - & - & 1 & 1 & 1 \\
\hline $\mathrm{KNO}_{3}$ & M & 5 & - & - & - & 5 & 3 & 3 \\
\hline $\mathrm{Ca}\left(\mathrm{NO}_{3}\right)_{2}$ & M & 5 & - & 5 & 5 & - & 4 & 4 \\
\hline $\mathrm{MgSO}_{4}$ & M & 2 & 2 & 2 & 2 & 2 & - & - \\
\hline $\mathrm{KCL}$ & M & - & 5 & - & - & - & 2 & 2 \\
\hline $\mathrm{CaCL}_{2}$ & M & - & 5 & - & - & - & 1 & 1 \\
\hline $\mathrm{NH}_{4} \mathrm{H}_{2} \mathrm{PO}_{4}$ & M & - & - & 1 & 1 & - & - & - \\
\hline $\mathrm{NH}_{4} \mathrm{NO}_{3}$ & $\mathrm{M}$ & - & - & 2 & 2 & 5 & - & - \\
\hline$\left(\mathrm{NH}_{4}\right)_{2} \mathrm{SO}_{4}$ & $\mathrm{M}$ & - & - & - & - & - & 2 & - \\
\hline $\mathrm{Mg}\left(\mathrm{NO}_{3}\right)_{2}$ & $\mathrm{M}$ & - & - & - & - & - & - & 2 \\
\hline Micronutrientes" & & 1 & 1 & 1 & 1 & 1 & 1 & 1 \\
\hline $\mathrm{Fe} \mathrm{EDTA}^{* *}$ & & 1 & 1 & 1 & 1 & 1 & 1 & 1 \\
\hline
\end{tabular}

* Composição da solução de micronutrientes $\left(\mathrm{g} \mathrm{L}^{-1}\right): \mathrm{H}_{3} \mathrm{BO}_{3}=2,86 ; \mathrm{MnCl}_{2.4} \mathrm{H}_{2} \mathrm{O}=1,81: \mathrm{ZnCl}_{2}=0,10: \mathrm{CuCl}_{2}=0,04$; $\mathrm{H}_{2} \mathrm{MoO}_{4} \cdot \mathrm{H}_{2} \mathrm{O}=0.02$.

** Dissolver 26,1 g de EDTA dissódico em $286 \mathrm{ml} \mathrm{de} \mathrm{NaOH}$ M: misturar com 24,0 g de FeSO 4 .7 $\mathrm{H}_{2} \mathrm{O}$ e arejar por uma noite e completar o volume a 1 litro. 


\subsubsection{Tratamentos e delineamento experimental}

Os dois experimentos em vasos tiveram oito tratamentos distribuídos em blocos ao acaso, com quatro repetições. Foram estudados os seguintes tratamentos:

1) completo

2) omissão de nitrogênio

3) omissão de fósforo

4) omissão de potássio

5) omissão de cálcio

6) omissão de magnésio

7) omissão de enxofre

8) testemunha.

Em todos os tratamentos foram incluídos os micronutrientes boro, cobre, ferro, manganês e zinco.

\subsubsection{Coleta do material vegetal}

As plantas foram colhidas quando os sintomas de carência se evidenciaram. Foram divididas em folhas novas (as da metade superior da planta), folhas velhas (as da metade inferior), ramos, "caule" (estaca) e raizes. Após a secagem a $65^{\circ} \mathrm{C}$, em estufa com circulação forçada de ar, cada parte foi pesada, moída e analisada para o nitrogênio (pelo método semi-micro Kjeldahl), após digestão sulfúrica; fósforo 
(pelo método colorimétrico com vanado-molibdato de amônio), após digestão nítrico-perclórica; potássio (por fotometria de chama), após digestão nítrico-perclórica; cálcio e magnésio (por espectrofotometria de absorção atômica), após digestão nítrico-perclórica, conforme a metodologia descrita por SARRUGE \& HAAG (1974); e enxofre pelo método indireto de cloreto de bário, de acordo com BATAGLIA (1976).

\subsubsection{Análise estatística}

Nos experimentos foi efetuada a comparação entre médias pelo teste TUKEY, quando o teste $\mathrm{F}$ foi significativo em uma probabilidade maior ou igual a $95 \%$, após ser realizada uma análise de variância dos resultados. Para a execução da análise estatística foi utilizado o programa estatístico SAS.

Nos dois experimentos de vasos os resultados foram analisados quanto à produção de material seco das folhas novas ou da metade superior da planta, folhas velhas ou da metade inferior da planta, ramos, caule e raízes, bem como a composição mineral dessas partes.

\subsection{Experimento no campo}

\subsubsection{Condições de instalação e condução do experimento}

Em um pomar com dez anos de idade, instalado na propriedade Miazaki, bairro Votorantim, Município de Ibiúna, Estado de São Paulo, foi utilizado um conjunto de 
plantas dos cultivares Bruno e Monty, as quais receberam os tratos culturais habituais. O solo foi classificado como Latossolo Vermelho Amarelo fase rasa, segundo o levantamento de solos Estado de São Paulo (BRASIL, 1960). Amostras de terra em torno das plantas foram colhidas no início do experimento, nas profundidades de 0 a $20 \mathrm{~cm}$ e de 20 a $40 \mathrm{~cm}$, e o resultado das suas análises são apresentados na Tabela 2.

Tabela 2. Resultado das análises químicas da terra de amostras retiradas no início da frutificação. Médias de 15 repetições.

\begin{tabular}{|c|c|c|c|c|c|c|c|c|c|c|}
\hline Profundidade & $\mathbf{P}$ & M.O. & $\mathrm{pH}$ & $\mathbf{K}$ & $\mathrm{Ca}$ & $\mathbf{M g}$ & $\mathbf{H}+\mathbf{A l}$ & $S$ & $\mathbf{T}$ & $\mathbf{V}$ \\
\hline $\mathrm{cm}$ & $\mathbf{m g} \mathbf{L}^{-1}$ & dag kg $^{-1}$ & $\mathrm{CaCl}_{2}$ & & & \multicolumn{2}{|c|}{ c $\mathrm{mol}_{\mathrm{c}} \mathrm{kg}^{-1}$} & & & $\%$ \\
\hline $0-20$ & 181,5 & 3,54 & 6,35 & 0,30 & 5,35 & 2,80 & 1,92 & 8,46 & 10,37 & 10,4 \\
\hline $20-40$ & 63,5 & 2,44 & 5,98 & 0,23 & 2,9 & 1,95 & 2,25 & 5,08 & 7,33 & 7,3 \\
\hline
\end{tabular}

Quinzenalmente foram retiradas amostras de cada planta, totalizando doze épocas de amostragem para o cultivar Bruno e treze para o cultivar Monty. Nas amostragens foram colhidos, a partir do início da frutificação, frutos e folhas dos ramos frutíferos, que tiveram sua composição química determinada. Com a finalidade de serem determinadas as épocas de amostragem, foi considerado o dia de $1 . \% 11 / 91$ como o da polinização em geral, tendo ocorrido em 28/10/91 o início da florada, em 1.\%/11/91 o auge da florada e em 7/11/91 o final da mesma. 
As épocas de amostragem foram então: 19/11/91 (época 1, terceira semana após a polinização); 3/12/91 (época 2, quinta semana após a polinização); 18/12/91 (época 3, sétima semana após a polinização); 3/01/92 (época 4, nona semana após a polinização); 14/01/92 (época 5, décima primeira semana após a polinização); 28/01/92 (época 6, décima terceira semana após a polinização); 11/02/92 (época 7, décima quinta semana após a polinização); 26/02/92 (época 8, décima sétima semana após a polinização); 11/03/92 (época 9, décima nona semana após a polinização); 25/03/92 (época 10, vigésima primeira semana após a polinização); 8/04/92 (época 11, vigésima terceira semana após polinização); 21/04/92 (época 12, vigésima quinta semana após a polinização); 6/05/92 (época 13, vigésima sétima semana após a polinização).

\subsubsection{Determinações}

Os frutos e folhas de ramos fnutíferos foram, após a secagem em estufa a $65^{\circ} \mathrm{C}$ com circulação forçada de ar, pesados, moídos e analisados quanto à composição de macronutrientes conforme foi descrito no item 3.1.3.

Tanto as análises das amostras vegetais como as de terra foram executadas nos laboratórios do Departamento de Química (Nutrição Mineral de Plantas) da ESALQ, pela metodologia descrita por SARRUGE e HAAG (1974) e por RAIJ et al. (1987).

Curvas de teores nas folhas e frutos e de extração pelos frutos nas épocas amostradas foram traçadas para os macronutrientes. Correlacionaram-se também os resultados dos teores de macronutrientes na folha amostrada com os teores de nutrientes no fruto e a extração de nutrientes pelo fruto, em cada cultivar. 


\section{RESULTADOS E DISCUSSÃO}

\subsection{Experimentos em casa-de-vegetação}

\subsubsection{Kiwi cultivar Bruno}

\subsubsection{Concentração de macronutrientes no tecido vegetal}

Os resultados das médias das concentrações de macronutrientes no tecido vegetal, separados para cada órgão da planta, são apresentados nas Tabelas 3 a 5 referentes à primeira coleta, e nas Tabelas 6 a 8 referentes à segunda coleta.

Tabela 3. Concentrações médias dos nutrientes nas folhas novas do cultivar Bruno, por tratamento, na primeira coleta. Médias de quatro repetições.

\begin{tabular}{lccccccc}
\hline & \multicolumn{7}{c}{ Teor no material seco } \\
\cline { 2 - 8 } Tratamentos & $\mathbf{N}$ & $\mathbf{P}$ & $\mathbf{K}$ & $\mathbf{C a}$ & $\mathbf{M g}$ & $\mathbf{S}$ \\
\cline { 2 - 8 } Completo & $1,83 \mathrm{ab}$ & $0,17 \mathrm{~b}$ & $1,07 \mathrm{ab}$ & $1,26 \mathrm{abc}$ & $0,39 \mathrm{bc}$ & $0,16 \mathrm{a}$ \\
Omissão de $\mathrm{N}$ & $1,37 \mathrm{~b}$ & $0,23 \mathrm{ab}$ & $1,28 \mathrm{ab}$ & $1,60 \mathrm{abc}$ & $0,38 \mathrm{bc}$ & $0,18 \mathrm{a}$ \\
Omissão de $\mathrm{P}$ & $2,39 \mathrm{a}$ & $0,18 \mathrm{~b}$ & $1,47 \mathrm{ab}$ & $1,59 \mathrm{abc}$ & $0,38 \mathrm{bc}$ & $0,11 \mathrm{a}$ \\
Omissão de $\mathrm{K}$ & $2,75 \mathrm{a}$ & $0,37 \mathrm{a}$ & $0,71 \mathrm{~b}$ & $1,82 \mathrm{a}$ & $0,59 \mathrm{a}$ & $0,17 \mathrm{a}$ \\
Omissão de $\mathrm{Ca}$ & $2,60 \mathrm{a}$ & $0,21 \mathrm{~b}$ & $2,47 \mathrm{a}$ & $0,92 \mathrm{bc}$ & $0,53 \mathrm{ab}$ & $0,12 \mathrm{a}$ \\
Omissão de Mg & $2,73 \mathrm{a}$ & $0,25 \mathrm{ab}$ & $1,61 \mathrm{ab}$ & $1,64 \mathrm{ab}$ & 0,17 & $\mathrm{~d}$ & $0,12 \mathrm{a}$ \\
Omissão de S & $2,35 \mathrm{ab}$ & $0,23 \mathrm{ab}$ & $1,72 \mathrm{ab}$ & $1,38 \mathrm{bc}$ & 0,24 & $\mathrm{~cd}$ & $0,09 \mathrm{a}$ \\
Testemunha & $1,38 \mathrm{~b}$ & $0,12 \mathrm{~b}$ & $0,84 \mathrm{ab}$ & $0,80 \mathrm{c}$ & 0,24 & $\mathrm{~cd}$ & $0,16 \mathrm{a}$ \\
\hline CV (\%) & 19,3 & 29,2 & 50,7 & 25,6 & 19,4 & 27,6 \\
\hline
\end{tabular}


Tabela 4. Concentrações médias dos nutrientes nas folhas velhas do cultivar Bruno, por tratamento, na primeira coleta. Médias de quatro repetições.

\begin{tabular}{|c|c|c|c|c|c|c|}
\hline \multirow[b]{2}{*}{ Tratamentos } & \multicolumn{6}{|c|}{ Teor no material seco } \\
\hline & $\mathbf{N}$ & $\mathbf{P}$ & $\mathbf{K}$ & $\mathbf{C a}$ & $\mathbf{M g}$ & $\mathbf{S}$ \\
\hline & \multicolumn{6}{|c|}{ dag $\mathrm{kg}^{-1}$} \\
\hline Completo & $2,47 \mathrm{a}$ & $0,18 \mathrm{ab}$ & $1,34 \mathrm{ab}$ & $1,71 \mathrm{ab}$ & $0,40 \mathrm{abc}$ & $0,13 \mathrm{ab}$ \\
\hline Omissão de $\mathrm{N}$ & $1,50 \mathrm{a}$ & $0,23 \mathrm{ab}$ & $2,07 \mathrm{a}$ & $1,51 \mathrm{abc}$ & $0,33 \mathrm{bc}$ & $0,15 a b$ \\
\hline Omissão de P & $2,42 a$ & $0,14 \mathrm{~b}$ & $1,88 \mathrm{a}$ & $1,53 \mathrm{abc}$ & $0,40 \mathrm{abc}$ & $0,15 a b$ \\
\hline Omissão de $\mathrm{K}$ & $2,27 \mathrm{a}$ & $0,31 \mathrm{a}$ & $0,30 \mathrm{~b}$ & $1,77 \mathrm{ab}$ & $0,58 \mathrm{a}$ & $0,15 \mathrm{ab}$ \\
\hline Omissão de $\mathrm{Ca}$ & $2,67 \mathrm{a}$ & $0,17 \mathrm{~b}$ & $1,55 \mathrm{ab}$ & $1,06 \mathrm{bc}$ & $0,49 a b$ & $0,19 a$ \\
\hline Omissão de Mg & $2,75 \mathrm{a}$ & $0,21 \mathrm{ab}$ & $1,83 \mathrm{ab}$ & $2,05 \mathrm{a}$ & $0,22 \quad \mathrm{c}$ & $0,12 \mathrm{ab}$ \\
\hline Omissão de S & $2,20 \mathrm{a}$ & $0,19 a b$ & $1,13 \mathrm{ab}$ & $1,74 \mathrm{ab}$ & $0,27 \quad \mathrm{c}$ & $0,09 \mathrm{~b}$ \\
\hline Testemunha & $1,48 \mathrm{a}$ & $0,12 \mathrm{~b}$ & $0,78 \mathrm{ab}$ & 0,69 & $0,22 \quad \mathrm{c}$ & $0,17 \mathrm{ab}$ \\
\hline CV $(\%)$ & 26,0 & 29,4 & 48,8 & 25,6 & 23,8 & 27,7 \\
\hline
\end{tabular}

Médias seguidas pela mesma letra. em cada coluna, não diferem entre si pelo teste de Tukey (S\%)

Tabela 5. Concentrações médias dos nutrientes nos ramos do cultivar Bruno, por tratamento, na primeira coleta. Médias de quatro repetições.

\begin{tabular}{|c|c|c|c|c|c|c|}
\hline \multirow[b]{2}{*}{ Tratamentos } & \multicolumn{6}{|c|}{ Teor no material seco } \\
\hline & $\mathbf{N}$ & $\mathbf{P}$ & $\mathbf{K}$ & $\mathrm{Ca}$ & Mg & $\mathbf{S}$ \\
\hline & \multicolumn{6}{|c|}{ dag $\mathrm{kg}^{-1}$} \\
\hline Completo & $0,91 \mathrm{bc}$ & $0,14 \mathrm{bc}$ & $0,84 \mathrm{ab}$ & $0,57 \mathrm{a}$ & $0,18 \mathrm{bc}$ & $0,15 \mathrm{a}$ \\
\hline Omissão de $N$ & $0,69 \mathrm{c}$ & $0,16 \mathrm{abc}$ & $0,74 \mathrm{ab}$ & $0,62 \mathrm{a}$ & $0,16 \mathrm{bc}$ & $0,17 \mathrm{a}$ \\
\hline Omissão de P & $1,01 \mathrm{abc}$ & $0,11 \quad \mathrm{c}$ & $1,11 \mathrm{a}$ & $0,84 \mathrm{a}$ & $0,22 a b$ & $0,14 a$ \\
\hline Omissão de K & $1,38 \mathrm{a}$ & $0,27 \mathrm{a}$ & $0,52 \mathrm{~b}$ & $0,85 \mathrm{a}$ & $0,32 \mathrm{a}$ & $0,15 \mathrm{a}$ \\
\hline Omissão de $\mathrm{Ca}$ & $1,14 \mathrm{abc}$ & $0,19 \mathrm{abc}$ & $0,86 \mathrm{ab}$ & $0,48 \mathrm{a}$ & $0,20 \mathrm{bc}$ & $0,13 \mathrm{a}$ \\
\hline Omissão de Mg & $1,23 \mathrm{ab}$ & $0,24 \mathrm{ab}$ & $0,94 a b$ & $0,80 \mathrm{a}$ & $0,09 \quad \mathrm{c}$ & $0,16 \mathrm{a}$ \\
\hline Omissão de S & $0,99 \mathrm{abc}$ & $0,17 \mathrm{abc}$ & $0,82 \mathrm{ab}$ & $0,66 \mathrm{a}$ & $0,12 \mathrm{bc}$ & $0,09 a$ \\
\hline Testemunha & $0,80 \mathrm{bc}$ & $0,12 \quad \mathrm{c}$ & $0,65 \mathrm{ab}$ & $0,62 \mathrm{a}$ & $0,14 \mathrm{bc}$ & $0,11 \mathrm{a}$ \\
\hline $\mathrm{CV}(\%)$ & 19,0 & 27,9 & 29,4 & 31,6 & 28,0 & 44,1 \\
\hline
\end{tabular}

Médias seguidas pela mesma letra. em cada coluna. não diferem entre si pelo teste de Tukey (5\%) 
Tabela 6. Concentrações médias dos nutrientes nas folhas novas do cultivar Bruno, por tratamento, na segunda coleta. Médias de quatro repetições.

\begin{tabular}{|c|c|c|c|c|c|c|}
\hline \multirow[b]{2}{*}{ Tratamentos } & \multirow[b]{2}{*}{$\mathbf{N}$} & \multicolumn{4}{|c|}{ Teor na matéria seca } & \multirow[b]{2}{*}{$\mathbf{S}$} \\
\hline & & $\mathbf{P}$ & $\mathbf{K}$ & Ca & $\mathbf{M g}$ & \\
\hline & \multicolumn{5}{|c|}{ dag $\mathrm{kg}^{-1}$} & \\
\hline Completo & $2,77 \mathrm{a}$ & $0,25 \mathrm{a}$ & $1,58 \mathrm{a}$ & $1,59 \mathrm{ab}$ & $0,35 \mathrm{a}$ & nd \\
\hline Omissão de N & $2,75 a$ & $0,71 \mathrm{a}$ & $4,40 \mathrm{a}$ & $1,77 \mathrm{a}$ & $0,36 \mathrm{a}$ & nd \\
\hline Omissão de P & $2,70 \mathrm{a}$ & $0,26 \mathrm{a}$ & $3,86 \mathrm{a}$ & $1,53 \mathrm{ab}$ & $0,55 \mathrm{a}$ & nd \\
\hline Omissão de $\mathrm{K}$ & nd & $0,64 \mathrm{a}$ & $2,45 \mathrm{a}$ & $1,86 \mathrm{a}$ & $0,45 \mathrm{a}$ & nd \\
\hline Omissão de Ca & $3,30 \mathrm{a}$ & $0,43 \mathrm{a}$ & $3,73 \mathrm{a}$ & $0,99 \mathrm{~b}$ & $0,66 \mathrm{a}$ & nd \\
\hline Omissão de Mg & $3,50 a$ & nd & nd & nd & nd & nd \\
\hline Omissão de S & $3,09 a$ & $0,29 a$ & $2,96 \mathrm{a}$ & $1,60 \mathrm{ab}$ & $0,37 \mathrm{a}$ & nd \\
\hline Testemunha & $2,55 \mathrm{a}$ & $0,37 \mathrm{a}$ & $2,39 a$ & $1,86 \mathrm{a}$ & $0,34 \mathrm{a}$ & nd \\
\hline CV $(\%)$ & 15,6 & 45,0 & 43,7 & 14,0 & 60,2 & - \\
\hline
\end{tabular}

Médias seguidas pela mesma letra, em cada coluna, não diferem entre si pelo teste de Tukey (5\%) nd = não determinado por insuficiência de material vegetal.

Tabela 7. Concentrações médias dos nutrientes nas folhas velhas do cultivar Bruno, por tratamento, na segunda coleta. Médias de quatro repetições.

\begin{tabular}{lcccccr}
\hline & \multicolumn{7}{c}{ Teor no material seco } \\
\cline { 2 - 6 } Tratamentos & $\mathbf{N}$ & $\mathbf{P}$ & $\mathbf{K}$ & $\mathbf{C a}$ & $\mathbf{M g}$ & $\mathbf{S}$ \\
\cline { 2 - 6 } Completo & $2,29 \mathrm{a}$ & $0,22 \mathrm{~b}$ & $1,49 \mathrm{~b}$ & $1,53 \mathrm{ab}$ & $0,28 \mathrm{a}$ & $0,17 \mathrm{a}$ \\
Omissão de $\mathrm{N}$ & $2,48 \mathrm{a}$ & $0,66 \mathrm{a}$ & $4,63 \mathrm{a}$ & $1,98 \mathrm{a}$ & $0,53 \mathrm{a}$ & nd \\
Omissão de $\mathrm{P}$ & $2,62 \mathrm{a}$ & $0,14 \mathrm{~b}$ & $2,09 \mathrm{~b}$ & $1,67 \mathrm{a}$ & $0,74 \mathrm{a}$ & $0,15 \mathrm{a}$ \\
Omissão de $\mathrm{K}$ & $3,28 \mathrm{a}$ & nd & nd & nd & nd & nd \\
Omissão de Ca & $3,33 \mathrm{a}$ & $0,34 \mathrm{ab}$ & $2,40 \mathrm{a}$ & $1,06 \mathrm{~b}$ & $0,65 \mathrm{a}$ & $0,16 \mathrm{a}$ \\
Omissão de Mg & $3,36 \mathrm{a}$ & $0,46 \mathrm{ab}$ & $2,83 \mathrm{~b}$ & $1,88 \mathrm{a}$ & $0,20 \mathrm{a}$ & nd \\
Omissão de S & $2,67 \mathrm{a}$ & $0,31 \mathrm{~b}$ & $2,14 \mathrm{~b}$ & $1,75 \mathrm{a}$ & $0,38 \mathrm{a}$ & $0,12 \mathrm{a}$ \\
Testemunha & $2,61 \mathrm{a}$ & $0,36 \mathrm{ab}$ & $1,84 \mathrm{~b}$ & $2,01 \mathrm{a}$ & $0,33 \mathrm{a}$ & nd \\
\hline CV (\%) & 23,7 & 29,6 & 19,5 & 11,0 & 62,2 & 7,0 \\
\hline
\end{tabular}

Médias seguidas pela mesma letra. em cada coluna. não diferem entre si pelo teste de Tukey (5\%) $n d=$ nõo determinado por insuficiência de material vegetal. 
Tabela 8. Concentrações médias dos nutrientes nos ramos do cultivar Bruno, por tratamento, na segunda coleta. Médias de quatro repetições.

\begin{tabular}{lccrrrr}
\hline & \multicolumn{7}{c}{ Teor no material seco } \\
\cline { 2 - 7 } \multicolumn{1}{c}{ Tratamentos } & $\mathbf{N}$ & $\mathbf{P}$ & $\mathbf{K}$ & $\mathbf{C a}$ & $\mathbf{M g}$ & $\mathbf{S}$ \\
\cline { 2 - 7 } Completo & $1,59 \mathrm{a}$ & $0,19 \mathrm{a}$ & $1,12 \mathrm{a}$ & $1,29 \mathrm{ab}$ & $0,21 \mathrm{a}$ & $0,21 \mathrm{a}$ \\
Omissão de $\mathrm{N}$ & $0,86 \mathrm{a}$ & nd & nd & nd & nd & nd \\
Omissão de P & $1,21 \mathrm{a}$ & $0,15 \mathrm{a}$ & $1,27 \mathrm{a}$ & $1,59 \mathrm{a}$ & $0,59 \mathrm{a}$ & $0,16 \mathrm{a}$ \\
Omissão de K & nd & nd & nd & nd & nd & nd \\
Omissão de Ca & $1,24 \mathrm{a}$ & $0,22 \mathrm{a}$ & $1,22 \mathrm{a}$ & $0,58 \mathrm{~b}$ & $0,38 \mathrm{a}$ & $0,15 \mathrm{a}$ \\
Omissão de Mg & $1,32 \mathrm{a}$ & $0,46 \mathrm{a}$ & $1,65 \mathrm{a}$ & $1,12 \mathrm{ab}$ & $0,67 \mathrm{a}$ & $0,22 \mathrm{a}$ \\
Omissão de S & $1,02 \mathrm{a}$ & $0,19 \mathrm{a}$ & $0,89 \mathrm{a}$ & $1,46 \mathrm{a}$ & $0,20 \mathrm{a}$ & $0,13 \mathrm{a}$ \\
Testemunha & $1,04 \mathrm{a}$ & $0,20 \mathrm{a}$ & $0,97 \mathrm{a}$ & $1,20 \mathrm{ab}$ & $0,19 \mathrm{a}$ & nd \\
\hline CV (\%) & 25,3 & 45,7 & 23,0 & 20,0 & 77,3 & 43,0 \\
\hline
\end{tabular}

Médias seguidas pela mesma letra, em cada coluna, não diferem entre si pelo teste de Tukey (5\%) $n d=$ não determinado por insuficiência de material vegetal.

Tabela 9. Concentrações médias dos nutrientes nas estacas e raizes do cultivar Bruno, por tratamento, na segunda coleta. Médias de quatro repetições.

\begin{tabular}{lcccccc}
\hline & \multicolumn{7}{c}{ Teor no material seco } \\
\cline { 2 - 7 } Tratamentos & $\mathbf{N}$ & $\mathbf{P}$ & $\mathbf{K}$ & $\mathbf{C a}$ & $\mathbf{M g}$ & $\mathbf{S}$ \\
\cline { 2 - 7 } Completo & $1,52 \mathrm{ab}$ & $0,16 \mathrm{ab}$ & $0,67 \mathrm{ab}$ & $1,15 \mathrm{ab}$ & $0,33 \mathrm{a}$ & $0,14 \mathrm{a}$ \\
Omissão de N & $0,99 \mathrm{ab}$ & $0,12 \mathrm{~b}$ & $0,69 \mathrm{ab}$ & $1,03 \mathrm{ab}$ & $0,41 \mathrm{a}$ & $0,15 \mathrm{a}$ \\
Omissão de P & $1,55 \mathrm{ab}$ & $0,13 \mathrm{~b}$ & $0,88 \mathrm{ab}$ & $1,34 \mathrm{a}$ & $0,55 \mathrm{a}$ & $0,15 \mathrm{a}$ \\
Omissão de K & $1,26 \mathrm{ab}$ & $0,16 \mathrm{ab}$ & $0,35 \mathrm{~b}$ & $1,42 \mathrm{a}$ & $0,52 \mathrm{a}$ & $0,17 \mathrm{a}$ \\
Omissão de Ca & $1,44 \mathrm{ab}$ & $0,19 \mathrm{ab}$ & $0,88 \mathrm{ab}$ & $0,72 \mathrm{~b}$ & $0,35 \mathrm{a}$ & $0,17 \mathrm{a}$ \\
Omissão de Mg & $1,09 \mathrm{ab}$ & $0,14 \mathrm{~b}$ & $0,63 \mathrm{ab}$ & $1,03 \mathrm{ab}$ & $0,11 \mathrm{a}$ & $0,18 \mathrm{a}$ \\
Omissão de S & $1,58 \mathrm{a}$ & $0,21 \mathrm{a}$ & $1,09 \mathrm{a}$ & $1,28 \mathrm{a}$ & $0,25 \mathrm{a}$ & $0,17 \mathrm{a}$ \\
Testemunha & $0,96 \mathrm{~b}$ & $0,15 \mathrm{ab}$ & $0,82 \mathrm{ab}$ & $1,12 \mathrm{ab}$ & $0,25 \mathrm{a}$ & $0,19 \mathrm{a}$ \\
\hline CV (\%) & 19,8 & 19,3 & 30,8 & 20,7 & 68,2 & 27,6 \\
\hline
\end{tabular}




\subsection{Concentração de nitrogênio}

$\mathrm{Na}$ primeira coleta, os teores de nitrogênio, nas folhas novas de kiwi cultivar Bruno, dos tratamentos "omissão de nitrogênio" e "testemunha", foram significativamente menores que os dos tratamentos "omissão de potássio", "omissão de magnésio", "omissão de cálcio" e "omissão de fósforo" (Tabela 3).

Embora não tenham sido estatisticamente significativas as diferenças entre os tratamentos "omissão de nitrogênio" e "testemunha" e o tratamento "completo", os valores absolutos dos mesmos são bastante diferentes, como pode ser observado na Tabela 3 e concordam com os valores apresentados por BATTELLI \& RENZI (1990).

Segundo os critérios de LALATTA (1985) e de SALE (1985), esses valores são considerados baixos. De acordo com o primeiro autor, teores adequados de nitrogênio situam-se entre 2,20 e 2,60 dag $\mathrm{kg}^{-1}$, considerando-se a lâmina foliar de kiwi, e, segundo SALE (1985), situam-se entre 2,0 e 2,5 dag kg-1, considerando-se as folhas completas de kiwi.

Nas folhas velhas de kiwi cultivar Bruno, os teores de nitrogênio nos tratamentos "testemunha" e "omissão de nitrogênio" não diferiram significativamente dos demais tratamentos (Tabela 4). Embora não tenha havido diferença estatisticamente significativa entre os tratamentos "testemunha" e "omissão de nitrogênio" em comparação com o tratamento "completo", os valores encontrados concordam com os de LALATTA (1985) e SALE (1985) e são considerados baixos nos tratamentos "testemunha" e "omissão de nitrogênio" e, adequado, no tratamento 
"completo" e nos demais. Segundo BATTELLI \& RENZI (1990), o valor encontrado no tratamento "completo" seria considerado alto. LALATTA (1985) citou valores entre 2,20 a 2,60 dag kg ${ }^{-1}$ e SALE (1985) apresentou os valores de 2,0 a 2,5 dag kg-1 como adequados, enquanto BATTELLI \& RENZI (1990) citaram o valor de 2,40 dag $\mathrm{kg}^{-1}$ como adequado.

O teor de nitrogênio nos ramos foi mais baixo no tratamento com "omissão de nitrogênio" do que nos demais, mas diferiu significativamente somente dos tratamentos "omissão de potássio" e "omissão de magnésio". Embora não tenha ocorrido diferença estatisticamente significativa entre os teores de nitrogênio para os tratamentos "omissão de nitrogênio" e "completo", seus valores absolutos estiveram em 0,69 e $0,91 \mathrm{dag} \mathrm{kg}^{-1}$ respectivamente (Tabela 5), houve grande diferença no aspecto das plantas dos tratamentos "omissão de nitrogênio" e "testemunha" em relação ao tratamento "completo". Nas plantas do tratamento "omissão de nitrogênio" e também naquelas do tratamento "testemunha", houve redução de crescimento tanto das folhas novas, como das folhas velhas e dos ramos. As folhas também apresentaram, no início, cor verde pálida, mudando, depois, para bronzeadas, enquanto nas plantas do tratamento "completo", as folhas apresentaram-se muito maiores, verde-escuras, bem separadas umas das outras, e os ramos eram bem compridos.

Quanto à segunda coleta, tanto nas folhas novas como em folhas velhas do cultivar Bruno, as concentrações de nitrogênio não diferiram significativamente entre os vários tratamentos, todos acima do nível crítico (Tabelas 6 e 7). Nos ramos, a concentração de nitrogênio teve valor absoluto menor no tratamento "omissão de 
nitrogênio" e maior no tratamento "completo", porém nenhum tratamento diferenciou-se significativamente dos demais (Tabela 8). No conjunto das estacas e raízes, a concentração de nitrogênio nos tratamentos "testemunha" e "omissão de nitrogênio" foram as mais baixas verificadas entre todos os tratamentos, mas somente a testemunha diferiu significativamente do tratamento "omissão de enxofre" (Tabela 9).

Tanto nas plantas do tratamento "testemunha" como nas de "omissão de nitrogênio", as folhas formadas apresentavam-se, na época da segunda coleta, com cor verde pálida e menores, delgadas, tendo os peciolos de cor avermelhada e mais finos. Nas plantas que sofreram "omissão de nitrogênio", com o passar do tempo, as folhas velhas evoluíram para apresentar manchas marrom-avermelhadas nos bordos, secando posteriormente. As folhas do terço superior esbranquiçaram-se no início, necrosando as margens em seguida, que se enrolaram para cima e para dentro. As folhas inferiores foram as primeiras a exibir os sintomas.

\subsection{Concentração de fósforo}

Na primeira coleta de folhas novas do cultivar Bruno, o teor de fósforo foi o mais baixo no tratamento "testemunha", diferindo significativamente somente do tratamento "omissão de potássio" (Tabela 3). Nas folhas velhas do cultivar Bruno, a concentração de fósforo foi mais baixa no tratamento "testemunha", que também só diferiu significativamente do tratamento "omissão de potássio" (Tabela 4). Nos ramos, a concentração de fósforo foi mais baixa nos tratamentos "testemunha" e "omissão de 
fósforo", os quais diferiram significativamente dos tratamentos "omissão de potássio" e "omissão de magnésio" (Tabela 5).

Os teores de fósforo nas folhas novas não diferiram significativamente nos tratamentos "omissão de fósforo" e "completo". LALATTA (1985), considerando as lâminas foliares de kiwi, apresentou o valor de $0,18 \mathrm{dag} \mathrm{kg}^{-1}$ como limite entre o valor baixo e adequado para a concentração de fósforo. SALE (1985), observando folhas completas de kiwi, relatou os teores de 0,18 a $0,20 \mathrm{dag} \mathrm{kg}^{-1}$ de fósforo como adequados. BATELLI \& RENZI (1990) avaliando lâminas foliares de kiwi do cultivar Hayward, apresentaram os valores 0,12 dag $\mathrm{kg}^{-1}$ como baixo e entre 0,13 e $0,21 \mathrm{dag} \mathrm{kg}^{-1}$ como teor de fósforo adequado. Esses teores concordam com os obtidos no presente experimento.

CRESSWELL (1989) propôs os valores de 0,18 a $0,25 \mathrm{dag} \mathrm{kg}^{-1}$ como padrões adequados de concentração de fósforo e o de $0,13 \mathrm{dag} \mathrm{kg}^{-1}$ ou mais baixo, como indicador de deficiência desse nutriente. Os valores encontrados nas folhas novas encontram-se no limiar entre baixo e adequado de acordo com LALATTA (1985) e SALE (1985).

Nas folhas velhas, os valores absolutos dos tratamentos diferem entre os tratamentos "testemunha" $\left(0,12 \mathrm{dag} \mathrm{kg}^{-1}\right)$, tratamento "omissão de fósforo" $\left(0,14\right.$ dag kg $\left.{ }^{1}\right)$ e tratamento "completo" $\left(0,18 \mathrm{dag} \mathrm{kg}^{-1}\right)$ (Tabela 4) e concordam com os valores apresentados por LALATTA (1985) e por SALE (1985) como baixos e adequado respectivamente. 
$\mathrm{Na}$ segunda coleta, a concentração de fósforo nas folhas novas do cultivar Bruno não diferiu significativamente entre os tratamentos (Tabela 6). Nas folhas velhas, essa concentração foi mais baixa no tratamento "omissão de fósforo", a qual diferiu significativamente apenas do tratamento com "omissão de nitrogênio" (Tabela 7). Nos ramos, esse teor foi mais baixo no tratamento "omissão de fósforo" que, entretanto, não diferiu significativamente dos outros tratamentos (Tabela 8). No conjunto das estacas e raízes, o teor desse nutriente foi mais baixo no tratamento "omissão de fósforo", o qual diferiu significativamente somente do tratamento "omissão de enxofre" (Tabela 9).

Nessa coleta, os teores de fósforo encontrados em folhas velhas concordam com os de SALE (1985) e de LALATTA (1985) e são considerados baixos, no tratamento "omissão de fósforo", e adequado no tratamento "completo".

\subsection{Concentração de potássio}

Na primeira coleta do cultivar Bruno, o teor de potássio em folhas novas foi o mais baixo no tratamento com "omissão de potássio", o qual diferiu significativamente apenas do tratamento "omissão de cálcio" (Tabela 3). Nas folhas velhas, o teor em potássio foi o mais baixo no tratamento "omissão de potássio", o qual diferiu significativamente dos tratamentos "omissão de nitrogênio" e "omissão de fósforo" (Tabela 4). Nos ramos, o teor de potássio foi o mais baixo no tratamento "omissão de potássio", o qual diferiu significativamente apenas do tratamento "omissão de fósforo" (Tabela 5). 
BATTELLI \& RENZI (1990), considerando as lâminas das folhas do cultivar Hayward de kiwi, apresentaram os valores 0,4 dag kg $^{-1}$ como baixa concentração de potássio e de 0,5 a $1,1 \mathrm{dag} \mathrm{kg}^{-1}$ como concentração adequada e 1,22 dag $\mathrm{kg}^{-1}$ ou acima, como concentração alta.

LALATTA (1985), para as lâminas foliares de kiwi, referiu-se aos teores abaixo de $1,60 \mathrm{dag} \mathrm{kg}^{-1}$ de potássio no material seco como baixos, valores entre 1,60 e 2,00 dag kg ${ }^{-1}$ como adequados e valores acima de $2,00 \mathrm{dag} \mathrm{kg}^{-1}$ como altos.

Segundo SALE (1985), nas folhas completas de kiwi são adequadas as concentrações de potássio na matéria seca da ordem de 1,80 a $2,20 \mathrm{dag} \mathrm{kg}^{-1}$.

CRESSWEL (1989) citou que em Nova Gales do Sul, Austrália, os sintomas de deficiência de potássio estavam geralmente associados com concentração abaixo de $0,7 \mathrm{dag} \mathrm{kg}^{-1}$ de potássio na folha. Esse autor propôs como desejável a concentração de potássio maior que 1,80 dag $\mathrm{kg}^{-1}$.

Nas folhas novas, os valores encontrados no tratamento "omissão de cálcio" foram altos o que pode ser explicado pelo fato de o cátion potássio não ter encontrado competição com o cátion cálcio nesse tratamento, tendo sido favorecida a sua absorção.

Os resultados nas folhas novas, no tratamento "omissão de potássio" e no "completo", comparados com os apresentados por BATTELLI \& RENZI (1990) são ambos considerados adequados. Segundo LALATTA (1985) e SALE (1985), os valores encontrados nesses tratamentos mencionados são ambos considerados baixos. 
Nas folhas velhas, os teores de potássio nos tratamentos "omissão de potássio" e "completo", embora não tenham diferido estatisticamente, enquadram-se em categorias diferentes segundo BATTELI \& RENZI (1990), sendo categoria teor baixo, o teor encontrado no tratamento "omissão de potássio" $\left(0,3 \mathrm{dag} \mathrm{kg}^{-1}\right)$ e alto, o valor encontrado no tratamento "completo" (1,34 dag kg-1). Enquanto isso, segundo LALATTA (1985) e SALE (1985), ambos os teores são considerados como baixos.

Com respeito à segunda coleta, nas folhas novas do cultivar Bruno não houve diferença significativa entre os tratamentos quanto à concentração de potássio (Tabela 6). Nas folhas velhas do cultivar Bruno, não houve material suficiente para a determinação da concentração de potássio no tratamento "omissão de potássio". A concentração de potássio mais baixa ocorreu no tratamento "completo", a qual foi significativamente diferente daquela dos tratamentos "omissão de nitrogênio" e "omissão de cálcio" (Tabela 7). Nos ramos não houve material suficiente para as análises laboratoriais nos tratamentos "omissão de potássio" e "omissão de nitrogênio", e a concentração de potássio não diferiu significativamente entre os demais tratamentos (Tabela 8). No conjunto das estacas e raízes, a concentração de potássio foi mais baixa no tratamento "omissão de potássio" que diferiu significativamente apenas do tratamento "omissão de enxofre" (Tabela 9). 


\subsection{Concentração de cálcio}

$\mathrm{Na}$ primeira coleta do cultivar Bruno, o teor de cálcio nas folhas novas foi o mais baixo no tratamento "testemunha" seguido pelo "omissão de cálcio" e só diferiu significativamente dos tratamento "omissão de potássio" e "omissão de magnésio" (Tabela 3). Nas folhas velhas, a concentração de cálcio foi menor no tratamento "testemunha", seguido pelo tratamento "omissão de cálcio", e só diferiu significativamente dos tratamentos "omissão de potássio" e "omissão de magnésio" (Tabela 4). Tanto nas folhas novas como nas velhas, o teor de cálcio encontrado nos tratamentos "omissão de cálcio" e "completo" são baixos, quando comparados com os apresentados como adequados por LALATTA (1985): 2,20 a 2,80 dag kg ${ }^{-1}$; por SALE (1985): 1,80 A 2,20 dag kg-1; e por BATTELLI \& RENZI (1990): 2,8 a 4,0 dag kg-1.

$\mathrm{Na}$ segunda coleta desse cultivar, nas folhas novas, a concentração de cálcio foi a mais baixa no tratamento "omissão de cálcio", o qual diferiu significativamente dos tratamentos "testemunha", "omissão de potássio" e "omissão de nitrogênio" (Tabela 6). Nas folhas velhas do cultivar Bruno, o teor de cálcio foi o mais baixo no tratamento "omissão de cálcio", o qual só não diferiu significativamente do tratamento "completo" (Tabela 7). Nos ramos, a concentração de cálcio foi a mais baixa no tratamento "omissão de cálcio", o qual diferiu significativamente dos tratamentos "omissão de fósforo" e "omissão de enxofre" (Tabela 8). No conjunto das estacas e raízes, o teor de cálcio foi o mais baixo no tratamento "omissão de cálcio", o qual diferiu significativamente dos tratamentos "omissão de potássio", "omissão de fósforo" e "omissão de enxofre" (Tabela 9). 


\subsection{Concentração de magnésio}

Na primeira coleta, a concentração de magnésio nas folhas novas do cultivar Bruno foi a mais baixa no tratamento "omissão de magnésio", o qual não diferiu significativamente apenas dos tratamentos "testemunha" e "omissão de enxofre" (Tabela 3). Nas folhas velhas, o teor desse nutriente foi o mais baixo no tratamento "testemunha" e "omissão de magnésio", diferindo significativamente apenas dos tratamentos "omissão de potássio" e "omissão de cálcio" (Tabela 4). Nos ramos, o teor de magnésio foi o mais baixo no tratamento "omissão de magnésio", o qual diferiu significativamente apenas dos tratamentos "omissão de potássio" e "omissão de fósforo" (Tabela 5).

Para as lâminas das folhas de kiwi cultivar Hayward, BATTELLI \& RENZI (1990) citaram teores de magnésio de 0,3 a 0,6 dag $\mathrm{kg}^{-1}$ como adequados, e o de 0,2 dag $\mathrm{kg}^{-1}$ como baixo. O teor de $0,7 \mathrm{dag} \mathrm{kg}^{-1}$ é relatado por esses autores como alto.

SALE (1985) apresentou os teores de 0,20 a $0,45 \mathrm{dag} \mathrm{kg}^{-1}$ como adequados para magnésio nas folhas completas de kiwi e LALATTA (1985) considerou os valores de 0,35 a $0,70 \mathrm{dag} \mathrm{kg}^{-1}$ como adequados e menores que $0,35 \mathrm{dag} \mathrm{kg}^{-1}$ como baixos, em lâminas foliares de kiwi.

CLARK \& SMITH (1987), ao estudarem a deficiência de magnésio em plantas de pomares comerciais de kiwi, observaram que as plantas com deficiência apresentavam concentrações de magnésio inferiores a $0,2 \mathrm{dag} \mathrm{kg}^{-1}$, na folha mais jovem plenamente expandida. 
Em ambos os tipos de folhas, foram verificadas, no presente experimento, as concentrações de magnésio mais elevadas nos tratamentos "omissão de potássio" e "omissão de cálcio", as quais podem ser explicadas devido às interações entre os cátions EPSTEIN (1974).

Nessa primeira coleta, nas folhas novas do cultivar Bruno, a concentração de magnésio encontrada no tratamento "omissão de magnésio" enquadra-se como baixa segundo os autores e a do tratamento "completo", como adequada. Nas folhas velhas, embora não tenha ocorrido diferença significativa entre os valores dos tratamentos "omissão de magnésio" e "completo", esses teores se enquadram em categorias diferentes, sendo baixo o primeiro $\left(0,2\right.$ dag $\left.\mathrm{kg}^{-1}\right)$ e adequado o segundo $\left(0,4\right.$ dag $\left.\mathrm{kg}^{-1}\right)$.

$\mathrm{Na}$ segunda coleta, a concentração de magnésio nas folhas velhas do cultivar Bruno foi a mais baixa no tratamento "omissão de magnésio", diferindo significativamente dos demais tratamentos (Tabela 7). Nos ramos do cultivar Bruno, essa concentração também não diferiu entre os tratamentos. No conjunto das estacas e raízes, ocorreu a mais baixa concentração de magnésio no tratamento "omissão de magnésio". Nas folhas novas do tratamento "omissão de magnésio", não houve material suficiente para a análise laboratorial.

\subsection{Concentração de enxofre}

$\mathrm{Na}$ primeira coleta, a concentração de enxofre nas folhas novas do cultivar Bruno foi mais baixa no tratamento "omissão de enxofre", o qual não diferiu 
significativamente dos demais (Tabela 3). Nas folhas velhas, essa concentração foi mais baixa também no tratamento "omissão de enxofre", diferindo significativamente apenas do tratamento "omissão de cálcio" (Tabela 4), enquanto nos ramos, a concentração de enxofre não foi significativamente diferente entre os tratamentos (Tabela 5).

SALE (1985) relatou os teores de enxofre entre 0,15 e $0,30 \mathrm{dag} \mathrm{kg}^{-1}$ como adequados nas folhas completas de kiwi, por sua vez, CRESSWELL (1989), apresentou como guia para Nova Gales do Sul (Austrália), com base em amostragens obtidas em fevereiro e na primeira folha após o fruto, os valores abaixo de 0,20 dag $\mathrm{kg}^{-1}$ como baixos; entre $0,25 \mathrm{dag} \mathrm{kg}^{-1}$ e $0,45 \mathrm{dag} \mathrm{kg}^{-1}$ como desejáveis e mais elevados que 0,57 dag $\mathrm{kg}^{-1}$ como tóxicos.

Nas folhas novas, os valores encontrados no presente experimento, para os tratamentos "omissão de enxofre" e "completo", situam-se como muito baixo e normal ou adequado respectivamente, de acordo com os autores.

Nas folhas velhas, o teor de enxofre no tratamento "omissão de enxofre" enquadra-se na categoria baixa, e, o valor encontrado no tratamento "completo" está ligeiramente abaixo do limite inferior apresentado por SALE (1985).

Para a segunda coleta, não foram executadas determinações de concentração de enxofre nas folhas novas do cultivar Bruno por falta de material. Em folhas velhas, entre os poucos tratamentos em que foi possível realizar essa análise, a concentração de enxofre foi mais baixa na "omissão de enxofre" (Tabela 7). Tanto nos ramos como no conjunto das estacas e raizes, a concentração de enxofre não diferiu significativamente entre os tratamentos (Tabelas 8 e 9). 


\subsubsection{Kiwi cultivar Monty}

\subsubsection{Concentração de macronutrientes no tecido vegetal}

Os resultados médios dos teores de nutrientes no tecido vegetal, separados de acordo com os órgãos da planta são apresentados nas Tabelas 10 a 12 referentes à primeira coleta e, nas Tabelas 13 a 16, referentes à segunda coleta.

Tabela 10. Concentrações médias dos nutrientes nas folhas novas do cultivar Monty, por tratamento, na primeira coleta. Médias de quatro repetições.

\begin{tabular}{|c|c|c|c|c|c|c|}
\hline \multirow[b]{2}{*}{ Tratamentos } & \multicolumn{6}{|c|}{ Teor no material seco } \\
\hline & $\mathrm{N}$ & $\mathbf{P}$ & $\mathbf{K}$ & $\mathrm{Ca}$ & Mg & $\mathbf{S}$ \\
\hline & 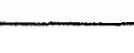 & - & - da & & & \\
\hline Completo & $2,43 \mathrm{a}$ & $0.20 \mathrm{abc}$ & $1.84 \mathrm{a}$ & $1.25 \mathrm{bc}$ & $0,38 \mathrm{ab}$ & $0,16 \mathrm{a}$ \\
\hline Omissão de $\mathrm{N}$ & $1,27 \mathrm{~b}$ & $0,26 a b$ & $1,96 \mathrm{a}$ & $2.04 \mathrm{a}$ & $0.36 \mathrm{ab}$ & $0,12 \mathrm{ab}$ \\
\hline Omissão de $\mathrm{P}$ & $2,40 a$ & $0,11 \quad c$ & $1.93 \mathrm{a}$ & $1.68 \mathrm{ab}$ & $0,34 \mathrm{ab}$ & $0,13 \mathrm{ab}$ \\
\hline Omissào de K & $2,68 \mathrm{a}$ & $0,31 \mathrm{a}$ & $0.77 \mathrm{a}$ & $2.11 \mathrm{a}$ & $0,44 a$ & $0,14 \mathrm{a}$ \\
\hline Omissão de $\mathrm{Ca}$ & $2.77 \mathrm{a}$ & $0 ., 28 \mathrm{ab}$ & $1,72 \mathrm{a}$ & $0.67 c$ & $0.45 \mathrm{a}$ & $0.17 \mathrm{a}$ \\
\hline Omissão de Mg & $2.45 \mathrm{a}$ & $0,28 \mathrm{ab}$ & $1,49 a$ & $1.60 \mathrm{ab}$ & $0.14 \mathrm{c}$ & $0.16 \mathrm{a}$ \\
\hline Omissão de S & $2,45 a$ & $0,19 b c$ & $1,98 \mathrm{a}$ & $1.49 \mathrm{ab}$ & $0.25 \mathrm{c}$ & $0.07 \mathrm{~b}$ \\
\hline Testemunha & $1,19 \mathrm{~b}$ & $0,13 c$ & $0,94 \mathrm{a}$ & $1,43 \mathrm{ab}$ & $0,33 \mathrm{ab}$ & $0,13 \mathrm{ab}$ \\
\hline $\mathrm{CV}(\%)$ & 12,3 & 22,1 & 47,8 & 20.1 & 19,6 & 19,5 \\
\hline
\end{tabular}

Médias seguidas pela mesma letra. ém cada coluna. năo diferem entre si pelo teste de Tukey (5\%) 
Tabela 11. Concentrações médias dos nutrientes nas folhas velhas do cultivar Monty, por tratamento, na primeira coleta. Médias de quatro repetições.

\begin{tabular}{|c|c|c|c|c|c|c|}
\hline \multirow[b]{2}{*}{ Tratamentos } & \multicolumn{6}{|c|}{ Teor no material seco } \\
\hline & $\mathbf{N}$ & $\mathbf{P}$ & $\mathbf{K}$ & $\mathrm{Ca}$ & $\mathbf{M g}$ & $S$ \\
\hline & \multicolumn{6}{|c|}{ dag $\mathrm{kg}^{-1}$} \\
\hline Completo & $2,25 \mathrm{a}$ & $0,15 \mathrm{ab}$ & $1,40 \mathrm{a}$ & $1,48 \mathrm{ab}$ & $0.40 \mathrm{bcd}$ & $0,14 \mathrm{a}$ \\
\hline Omissão de N & $1,22 \mathrm{~b}$ & $0,22 \mathrm{a}$ & $1,68 \mathrm{a}$ & $2,15 \mathrm{a}$ & $0,45 \mathrm{abc}$ & $0,12 \mathrm{ab}$ \\
\hline Omissão de P & $2,35 \mathrm{a}$ & $0,09 \mathrm{~b}$ & $1,24 a b$ & $1,62 \mathrm{ab}$ & $0,34 \mathrm{bcd}$ & $0,14 a$ \\
\hline Omissão de $\mathrm{K}$ & $2,45 \mathrm{a}$ & $0,24 \mathrm{a}$ & $0,47 \mathrm{~b}$ & $2,10 \mathrm{a}$ & $0,58 \mathrm{a}$ & $0,14 \mathrm{a}$ \\
\hline Omissão de $\mathrm{Ca}$ & $2,74 \mathrm{a}$ & $0,24 \mathrm{a}$ & $1,19 a b$ & $0,79 \mathrm{c}$ & $0,48 \mathrm{ab}$ & $0,16 \mathrm{a}$ \\
\hline Omissão de Mg & $2,34 \mathrm{a}$ & $0,18 \mathrm{ab}$ & $1,32 \mathrm{ab}$ & $1,74 \mathrm{ab}$ & $0,14 \mathrm{c}$ & $0,16 \mathrm{a}$ \\
\hline Omissão de S & $2,19 a$ & $0.15 \mathrm{ab}$ & $1,27 \mathrm{ab}$ & $1,46 \mathrm{ab}$ & 0.29 cde & $0,12 b$ \\
\hline Testemunha & $1,05 \mathrm{~b}$ & $0,10 \mathrm{~b}$ & $0,77 \mathrm{ab}$ & $1,22 \mathrm{bc}$ & 0,28 & $0,12 \mathrm{ab}$ \\
\hline $\mathrm{CV}(\%)$ & 13,5 & 22,0 & 32,4 & 17,8 & 18,3 & 18,8 \\
\hline
\end{tabular}

Médias seguidas pela mesma letra, em cada coluna, não diferem entre si pelo teste de Tukey (5\%)

Tabela 12. Concentrações médias dos nutrientes nos ramos do cultivar Monty, por tratamento, na primeira coleta. Médias de quatro repetições.

\begin{tabular}{|c|c|c|c|c|c|c|}
\hline \multirow[b]{2}{*}{ Tratamentos } & \multicolumn{6}{|c|}{ Teor no material seco } \\
\hline & $\mathbf{N}$ & $P$ & $\mathbf{K}$ & Ca & Mg & S \\
\hline & \multicolumn{6}{|c|}{ dag $\mathrm{kg}^{-1}$} \\
\hline Completo & $0,89 \mathrm{ab}$ & $0,14 a b$ & $0,93 \mathrm{ab}$ & $0,50 \mathrm{a}$ & $0.14 \mathrm{a}$ & $0,13 \mathrm{a}$ \\
\hline Omissão de N & $0,61 \mathrm{~b}$ & $0.14 a b$ & $1,10 \mathrm{a}$ & $0,94 \mathrm{a}$ & $0.20 \mathrm{a}$ & $0,12 \mathrm{ab}$ \\
\hline Omissão de P & $0,95 \mathrm{ab}$ & $0,06 \quad c$ & $1,13 \mathrm{a}$ & $0,60 \mathrm{a}$ & $0,14 \mathrm{a}$ & $0,13 \mathrm{a}$ \\
\hline Omissão de $\mathrm{K}$ & $1,28 \mathrm{a}$ & $0,19 a$ & $0,42 b$ & $0,62 \mathrm{a}$ & $0.20 \mathrm{a}$ & $0,11 \mathrm{ab}$ \\
\hline Omissão de $\mathrm{Ca}$ & $1,45 \mathrm{a}$ & $0.19 a$ & $0,96 \mathrm{ab}$ & $0,25 \mathrm{a}$ & $0.21 \mathrm{a}$ & $0,12 \mathrm{ab}$ \\
\hline Omissão de Mg & $0,93 \mathrm{ab}$ & $0,16 a b$ & $0,77 \mathrm{ab}$ & $0,80 \mathrm{a}$ & $0,05 \mathrm{a}$ & $0,12 \mathrm{a}$ \\
\hline Omissão de S & $1,49 a$ & $0.14 \mathrm{ab}$ & $1,05 \mathrm{a}$ & $1.14 \mathrm{a}$ & $0.21 \mathrm{a}$ & $0.07 b$ \\
\hline Testemunha & $0,61 \mathrm{~b}$ & $0,10 \mathrm{bc}$ & $0,79 \mathrm{ab}$ & $1,20 \mathrm{a}$ & $0,24 \mathrm{a}$ & $0,11 \mathrm{ab}$ \\
\hline $\mathrm{CV}(\%)$ & 25,5 & 21,9 & 26.8 & 67.9 & 62,5 & 19,6 \\
\hline
\end{tabular}


Tabela 13. Concentrações médias dos nutrientes nas folhas novas do cultivar Monty, por tratamento, na segunda coleta. Médias de quatro repetições.

\begin{tabular}{|c|c|c|c|c|c|c|}
\hline \multirow[b]{2}{*}{ Tratamentos } & \multicolumn{6}{|c|}{ Teor no material seco } \\
\hline & $\mathbf{N}$ & $\mathbf{P}$ & $\mathbf{K}$ & $\mathrm{Ca}$ & $\mathrm{Mg}$ & $S$ \\
\hline & & & - da & & & \\
\hline Completo & $2,11 \mathrm{a}$ & $0,19 a b$ & $3,29 a$ & $1,51 \mathrm{a}$ & $0,41 \mathrm{bc}$ & $0,22 \mathrm{a}$ \\
\hline Omissão de $N$ & $2,75 \mathrm{a}$ & $0,38 \mathrm{a}$ & $4,17 \mathrm{a}$ & $1,26 \mathrm{ab}$ & $0,34 \mathrm{bc}$ & nd \\
\hline Omissão de P & $2,34 \mathrm{a}$ & $0,10 \mathrm{~b}$ & $2,45 \mathrm{a}$ & $1,28 \mathrm{ab}$ & $0,36 \mathrm{bc}$ & $0,17 \mathrm{a}$ \\
\hline Omissão de K & $2,92 \mathrm{a}$ & $0,36 \mathrm{a}$ & $1,79 \mathrm{a}$ & $1,65 \mathrm{a}$ & $0,69 a$ & nd \\
\hline Omissão de $\mathrm{Ca}$ & $2,64 \mathrm{a}$ & $0,20 \mathrm{ab}$ & $1,53 \mathrm{a}$ & $0,65 \mathrm{~b}$ & $0,49 \mathrm{ab}$ & $0,18 \mathrm{a}$ \\
\hline Omissão de $\mathrm{Mg}$ & $2,71 \mathrm{a}$ & $0,28 \mathrm{ab}$ & $2,41 \mathrm{a}$ & $1.71 \mathrm{a}$ & $0.21 \mathrm{c}$ & $0,15 \mathrm{a}$ \\
\hline Omissão de S & $2,17 \mathrm{a}$ & $0,19 a b$ & $2,96 \mathrm{a}$ & $1,58 \mathrm{a}$ & $0,43 \mathrm{~b}$ & $0.16 \mathrm{a}$ \\
\hline Testemunha & $2,48 \mathrm{a}$ & $0,42 \mathrm{a}$ & $3,04 \mathrm{a}$ & $1,56 \mathrm{a}$ & $0,38 \mathrm{bc}$ & nd \\
\hline CV $(\%)$ & 22,2 & 31,8 & 32,0 & 17.4 & 18.2 & 24,5 \\
\hline
\end{tabular}

Médias seguidas pela mesma letra. em cada coluna. não diferem entre si pelo teste de Tukey (5\%) nd $=$ não determinado por insuficiciência de material vegetal.

Tabela 14. Concentrações médias dos nutrientes nas folhas velhas do cultivar Monty, por tratamento na segunda coleta. Médias de quatro repetições.

\begin{tabular}{|c|c|c|c|c|c|c|}
\hline \multirow[b]{2}{*}{ Tratamentos } & \multicolumn{6}{|c|}{ Teor no material seco } \\
\hline & $\mathrm{N}$ & $\mathbf{P}$ & $\mathbf{K}$ & Ca & $\mathrm{Mg}$ & $\mathrm{S}$ \\
\hline & 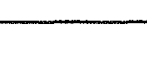 & 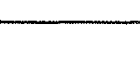 & dag & & & \\
\hline Completo & $2,37 \mathrm{abc}$ & $0,20 \mathrm{bc}$ & $2,07 a b c$ & $1,36 \mathrm{ab}$ & $0,38 \mathrm{ab}$ & $0.14 \mathrm{a}$ \\
\hline Omissão de $\mathrm{N}$ & $2.15 \mathrm{c}$ & $0.42 \mathrm{a}$ & $4,56 \mathrm{a}$ & $1,83 \mathrm{a}$ & $0,51 \mathrm{ab}$ & nd \\
\hline Omissão de P & $2,05 \mathrm{c}$ & $0.09 \mathrm{c}$ & $1,97 \mathrm{bc}$ & $1,62 \mathrm{ab}$ & $0,37 \mathrm{ab}$ & $0.13 \mathrm{a}$ \\
\hline Omissão de $K$ & $3,47 \mathrm{ab}$ & $0,41 \mathrm{ab}$ & $1,00 \quad c$ & $1,70 \mathrm{ab}$ & $0,75 a$ & $0,26 \mathrm{a}$ \\
\hline Omissão de Ca & $3,01 a b c$ & $0,23 \mathrm{bc}$ & $2.22 \mathrm{bc}$ & $0,72 \mathrm{~b}$ & $0.61 \mathrm{ab}$ & $0.15 \mathrm{a}$ \\
\hline Omissão de Mg & $2.89 \mathrm{abc}$ & $0.28 \mathrm{ab}$ & $2.64 \mathrm{abc}$ & $1,94 \mathrm{a}$ & $0.23 \mathrm{~b}$ & $0,23 \mathrm{a}$ \\
\hline Omissão de S & $2,34 \mathrm{bc}$ & $0,27 \mathrm{ab}$ & $4,08 \mathrm{ab}$ & $1.65 \mathrm{ab}$ & $0,56 \mathrm{ab}$ & $0.16 \mathrm{a}$ \\
\hline Testemunha & $3,78 a$ & $0,41 \mathrm{a}$ & $3,94 \mathrm{ab}$ & $1.56 \mathrm{ab}$ & $0.42 \mathrm{ab}$ & nd \\
\hline CV $(\%)$ & 13.2 & 21,2 & 27,7 & 21,3 & 32,7 & 40.0 \\
\hline
\end{tabular}

Médias seguidas pela mesma letra. em cada coluna. não diferem entre si pelo teste de Tukey (5\%) nd = năo determinado por insuficiência de material vegetal. 
Tabela 15. Concentrações médias dos nutrientes nos ramos do cultivar Monty, por tratamento, na segunda coleta. Médias de quatro repetições.

\begin{tabular}{|c|c|c|c|c|c|c|}
\hline \multirow[b]{2}{*}{ Tratamentos } & \multicolumn{6}{|c|}{ Teor no material seco } \\
\hline & $N$ & $\mathbf{P}$ & $\mathrm{K}$ & $\mathrm{Ca}$ & $\mathrm{Mg}$ & S \\
\hline & & 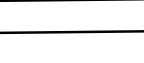 & $-\mathrm{da}$ & & & \\
\hline Completo & $1.23 \mathrm{a}$ & $0,17 \mathrm{~b}$ & $1,19 \mathrm{a}$ & $1.06 \mathrm{abc}$ & $0,26 \mathrm{ab}$ & $0,09 a$ \\
\hline Omissão de N & $1,07 \mathrm{a}$ & $0,16 b c$ & $1,53 \mathrm{a}$ & nd & nd & nd \\
\hline Omissão de $P$ & $1,20 \mathrm{a}$ & $0,08 \quad \mathrm{c}$ & $1,13 \mathrm{a}$ & $0,73 b c$ & $0,18 \mathrm{~b}$ & $0,17 \mathrm{a}$ \\
\hline Omissão de K & nd & $0,31 \mathrm{a}$ & $1,23 \mathrm{a}$ & $1,20 \mathrm{abc}$ & $0,46 a$ & nd \\
\hline Omissão de $\mathrm{Ca}$ & $1,49 a$ & $0,19 \mathrm{~b}$ & $1,38 \mathrm{a}$ & $0,50 \quad c$ & $0,32 \mathrm{ab}$ & $0,13 \mathrm{a}$ \\
\hline Omissão de Mg & $1,50 \mathrm{a}$ & $0,24 \mathrm{ab}$ & $1,74 \mathrm{a}$ & $1,30 \mathrm{ab}$ & $0.16 \mathrm{~b}$ & $0.17 a$ \\
\hline Omissão de S & $1,22 \mathrm{a}$ & $0,18 \mathrm{~b}$ & $1,89 a$ & $1.16 \mathrm{abc}$ & $0.29 \mathrm{ab}$ & $0,15 \mathrm{a}$ \\
\hline Testemunha & $1,16 \mathrm{a}$ & $0,24 \mathrm{ab}$ & $2,19 a$ & $1,52 \mathrm{a}$ & $0,23 \mathrm{ab}$ & nd \\
\hline $\mathrm{CV}(\%)$ & 21,8 & 14,2 & 24,6 & 21,2 & 31,7 & 29,2 \\
\hline
\end{tabular}

Médias seguidas pela mesma letra. em cada coluna. não diferem entre si pelo teste de Tukey (5\%) nd = não determinado por insuficiência de material vegetal.

Tabela 16. Concentrações médias dos nutrientes nas estacas e raizes do cultivar Monty, por tratamento, na segunda coleta. Médias de quatro repetições.

\begin{tabular}{lcccccc}
\hline & \multicolumn{7}{c}{ Teor no material seco } \\
\cline { 2 - 7 } \multicolumn{1}{c}{ Tratamentos } & $\mathbf{N}$ & $\mathbf{P}$ & $\mathbf{K}$ & $\mathbf{C a}$ & $\mathbf{M g}$ & $\mathrm{S}$ \\
\cline { 2 - 7 } Completo & $1,29 \mathrm{ab}$ & $0,11 \mathrm{abc}$ & $0,74 \mathrm{ab}$ & $1,07 \mathrm{a}$ & $0.18 \mathrm{ab}$ & $0,12 \mathrm{a}$ \\
Omissão de $\mathrm{N}$ & $0,95 \mathrm{ab}$ & $0,10 \mathrm{bc}$ & $0,63 \mathrm{ab}$ & $0,82 \mathrm{a}$ & $0.16 \mathrm{ab}$ & $0,14 \mathrm{a}$ \\
Omissão de $\mathrm{P}$ & $1,31 \mathrm{ab}$ & $0,08 \mathrm{c}$ & $1,17 \mathrm{a}$ & $0,88 \mathrm{a}$ & $0.20 \mathrm{ab}$ & $0,22 \mathrm{a}$ \\
Omissão de $\mathrm{K}$ & $1,13 \mathrm{ab}$ & $0,12 \mathrm{abc}$ & $0,44 \mathrm{~b}$ & $1,02 \mathrm{a}$ & $0,19 \mathrm{ab}$ & $0,14 \mathrm{a}$ \\
Omissão de $\mathrm{Ca}$ & $1,43 \mathrm{a}$ & $0,17 \mathrm{a}$ & $1,09 \mathrm{a}$ & $0,77 \mathrm{a}$ & $0,23 \mathrm{a}$ & $0.15 \mathrm{a}$ \\
Omissão de $\mathrm{Mg}$ & $1,24 \mathrm{ab}$ & $0,16 \mathrm{ab}$ & $0,96 \mathrm{ab}$ & $1,02 \mathrm{a}$ & $0,14 \mathrm{~b}$ & $0,14 \mathrm{a}$ \\
Omissão de $\mathrm{S}$ & $1,04 \mathrm{ab}$ & $0,13 \mathrm{abc}$ & $1,11 \mathrm{a}$ & $0,99 \mathrm{a}$ & $0,23 \mathrm{a}$ & $0,12 \mathrm{a}$ \\
Testemunha & $0.83 \mathrm{~b}$ & $0,13 \mathrm{abc}$ & $1,07 \mathrm{a}$ & $0,97 \mathrm{a}$ & $0,23 \mathrm{ab}$ & $0,17 \mathrm{a}$ \\
\hline CV $(\%)$ & 19,2 & 23.4 & 26,6 & 21,9 & 20.0 & 31,5 \\
\hline
\end{tabular}




\subsection{Concentração de nitrogênio}

Na primeira coleta de kiwi cultivar Monty, a concentração de nitrogènio nas folhas novas e nas folhas velhas foi mais baixa nos tratamentos "testemunha" e "omissão de nitrogènio", os quais diferiram significativamente dos demais (Tabelas 10 e 11). Nos ramos, a concentração de nitrogènio foi mais baixa também nos tratamentos "testemunha" e "omissão de nitrogènio", os quais diferiram significativamente apenas dos tratamentos "omissão de potássio", "omissão de cálcio" e "omissão de enxofre" (Tabela 12). Em ambos os tipos de folhas, as concentrações de nitrogènio nos tratamentos "omissão de nitrogènio" e "completo" são coerentes com a literatura, enquadrando-se nos níveis baixo e adequado respectivamente.

A pequena altura das plantas e o pequeno tamanho das folhas que apresentaram cor verde-amarelada, as quais em seguida tornaram-se bronze-avermelhadas, foram verificados em todas as plantas do tratamento "omissão de nitrogènio".

Na segunda coleta, a concentração de nitrogènio nas folhas novas do cultivar Monty não diferiu significativamente em nenhum tratamento, tendo sido ligeiramente menor no tratamento "completo" (Tabela 13). Nas folhas velhas, a concentração de nitrogènio foi menor nos tratamentos "omissão de fósforo" e "omissão de nitrogènio", os quais diferiram signifícativamente dos tratamentos "testemunha" e "omissão de potássio" (Tabela 14). 
Ainda com relação à segunda coleta, nos ramos, a concentração de nitrogênio foi a menor no tratamento "omissão de nitrogênio", o qual não diferiu significativamente de nenhum outro tratamento (Tabela 15). No conjunto das estacas e raízes, a concentração de nitrogênio foi a menor no tratamento "testemunha", o qual diferiu significativamente apenas do tratamento "omissão de cálcio" (Tabela 16).

Nas folhas novas, a concentração de nitrogênio no tratamento "completo" classificou-se como adequada de acordo com SALE (1985) e BATTELLI \& RENZI (1990). As concentrações nos demais tratamentos estão dentro dos limites propostos por CRESSWELL (1989). A concentração encontrada no tratamento "omissão de nitrogênio" pode ser classificada, segundo SALE (1985), LALATTA (1985) e BATTELLI \& RENZI (1990), como alta e isso pode ser devido ao fato de todo o nitrogênio de reserva da planta ter se dirigido para as folhas pequenas formadas nesse tratamento, concentrando-se ali. A concentração de nitrogênio foi mais alta no tratamento "omissão de potássio", que também produziu poucas folhas novas.

Nas folhas velhas, a concentração de nitrogênio foi maior no tratamento "testemunha", onde deve ter ocorrido concentração desse nutriente nas poucas e pequenas folhas formadas.

\subsection{Concentração de fósforo}

Os resultados da primeira coleta mostraram que a concentração de fósforo nas folhas novas do cultivar Monty foi mais baixa no tratamento "omissão de fósforo", não diferindo significativamente dos tratamentos "completo", "omissão de 
enxofre" e "testemunha", tendo, porém, diferido dos demais (Tabela 10).

Nas folhas velhas do cultivar Monty, a concentraçào de fósforo foi mais baixa no tratamento "omissão de fósforo", o qual diferiu significativamente apenas dos tratamentos "omissão de potássio", "omissão de cálcio" e "omissào de nitrogênio" (Tabela 11).

Nos ramos do cultivar Monty, a concentraçào de fósforo foi menor no tratamento "omissào de fósforo", o qual só não diferiu significativamente do tratamento "testemunha", diferindo significativamente dos demais tratamentos (Tabela 12).

Embora não tenham diferido significativamente, os valores absolutos dos tratamentos "omissào de fósforo" e "completo" nas folhas novas são bastante diferentes e, segundo BATTELLI \& RENZI (1990), CRESSWELL (1989), SALE (1985) e LALATTA (1985), classificam-se como baixo e adequado respectivamente.

Nas folhas velhas, a concentração de fósforo no tratamento "omissão de fósforo" foi quase a metade da encontrada no tratamento "completo" e ambas sào coerentes com os valores referidos por BATTELLI \& RENZI (1990) que analisaram lâminas foliares do cultivar Hayward, classificando-se os teores como baixo e adequado respectivamente. Segundo os outros autores eles classificam-se ambos como baixos.

Na segunda coleta de folhas novas do cultivar Monty, a concentração de fósforo foi mais baixa no tratamento "omissão de fósforo", o qual diferiu significativamente dos tratamentos "testemunha", "omissào de nitrogênio", e "omissào de potássio" (Tabela 13). Nas folhas velhas, a concentraçào de fósforo foi mais baixa no tratamento "omissào de fósforo", o qual nào diferiu significativamente dos 
tratamentos "omissão de cálcio" e "completo" (Tabela 14).

Ainda na segunda coleta, nos ramos desse cultivar, a concentração de fósforo foi menor no tratamento "omissão de fósforo", e diferiu significativamente de todos os tratamentos, com exceção do tratamento "omissão de nitrogènio" (Tabela 15) e, no conjunto das estacas e raizes, a concentração de fósforo foi menor no tratamento "omissão de fósforo", que diferiu significativamente dos tratamentos "omissão de cálcio" e "omissão de magnésio" (Tabela 16).

BATTELLI \& RENZI (1990) propuseram concentrações entre 0,13 e 0,21 dag kg ${ }^{-1}$ como adequadas em lâminas de folhas de kiwi Hayward, e 0,12 dag kg-1 ou menor como concentração baixa de fósforo. CRESSWELL (1989) propôs as concentrações entre 0,18 e $0,25 \mathrm{dag} \mathrm{kg}^{-1}$ de fósforo como adequadas e $0,13 \mathrm{dag}_{\mathrm{kg}^{-1}}$ ou menor como deficientes. SALE (1985) considerou entre 0,18 e $0,20 \mathrm{dag} \mathrm{kg}^{-1}$ como concentrações adequadas de fósforo em folhas completas e LALATTA (1985), considerando lâminas foliares de kiwi, apontou as concentrações entre 0,18 e $0,25 \mathrm{dag} \mathrm{kg}^{-1}$ como adequadas e, menores que 0,18 dag $\mathrm{kg}^{-1}$ como deficientes.

Nas folhas novas como nas velhas, as concentrações no tratamento "omissão de fósforo" classificam-se como baixas, de acordo com esses autores e, no tratamento "completo", como adequadas.

Ainda em ambos os tipos de folhas, as concentrações de fósforo foram maiores nos tratamentos "omissão de nitrogênio" e "omissão de potássio", os quais produziram menos folhas, podendo-se dizer que houve concentração desse nutriente nas poucas folhas formadas. 


\subsection{Concentração de potássio}

Os resultados da primeira coleta mostraram que a concentração de potássio nas folhas novas do cultivar Monty não diferiu significativamente em nenhum dos tratamentos, tendo sido mais baixa no tratamento "omissão de potássio" (Tabela 10). Nas folhas velhas do cultivar Monty, a concentração de potássio foi menor no tratamento "omissão de potássio", o qual diferiu significativamente dos tratamentos "omissão de nitrogènio" e "completo" (Tabela 11). Nos ramos do cultivar Monty, a concentração de potássio foi mais baixa no tratamento "omissão de potássio", o qual diferiu significativamente dos tratamentos "omissão de fósforo", "omissão de nitrogênio" e "omissão de enxofre" (Tabela 12).

Embora não tenham diferido significativamente entre si, os valores absolutos dos tratamentos "omissão de potássio" e "completo" nas folhas novas diferem na ordem de cinqüenta por cento e estão coerentes com os apresentados por CRESSWELL (1989), interpretados como baixo e adequado respectivamente; o mesmo se refere a SALE (1985) e LALATTA (1985). Considerando-se os limites indicados por BATTELLI \& RENZI (1990) nas lâminas de folhas do cultivar Hayward, ambas as concentrações estariam na mesma classe, sendo interpretadas como adequadas ou normais.

Nas folhas velhas, as concentrações de potássio nos tratamentos "omissão de potássio" e "completo" apresentaram valores que de acordo com BATTELLI \& RENZI (1990) classificar-se-iam como baixo e alto respectivamente. 
De acordo com CRESSWELL (1989), SALE (1985) e LALATTA (1985), ambos os valores estariam baixos.

Na segunda coleta, observou-se que nas folhas novas do cultivar Monty, a concentração de potássio não diferiu significativamente em nenhum tratamento, tendo sido mais baixa no tratamento "omissão de cálcio", seguido pelo tratamento "omissão de potássio" (Tabela 13). Nas folhas velhas desse cultivar, a concentração de potássio foi a menor no tratamento "omissão de potássio", o qual diferiu significativamente dos tratamentos "omissão de nitrogênio", "omissão de enxofre" e "testemunha" (Tabela 14). Nos ramos desse cultivar, a concentração de potássio não diferiu significativamente em nenhum tratamento (Tabela 15).

No conjunto das estacas e raízes do cultivar Monty, a concentração de potássio foi mais baixa no tratamento "omissão de potássio", o qual diferiu significativamente dos tratamentos "omissão de fósforo", "omissão de enxofre", "omissão de cálcio" e "testemunha" (Tabela 16).

\subsection{Concentração de cálcio}

$\mathrm{Na}$ primeira coleta, a concentração de cálcio nas folhas novas do cultivar Monty foi mais baixa no tratamento "omissão de cálcio", o qual só não diferiu significativamente do tratamento "completo", diferindo de todos os demais (Tabela 10). Nas folhas velhas desse cultivar, a concentração de cálcio foi mais baixa no tratamento 
"omissão de cálcio", o qual não diferiu significativamente apenas do tratamento "testemunha", tendo diferido significativamente de todos os demais (Tabela 11). Nos ramos desse cultivar, a concentração de cálcio foi a mais baixa no tratamento "omissão de cálcio", porém este não diferiu significativamente de nenhum tratamento (Tabela 12).

LALATTA (1985) citou a faixa de 2,20 a 2,80 $\mathrm{dag} \mathrm{kg}^{-1}$ como adequada para a concentração de cálcio nas lâminas foliares de kiwi. SALE (1985) referiu-se aos limites 3,0 a 4,0 dag kg-1 como adequados para folhas completas de kiwi e BATTELLI \& RENZI (1990) propuseram as concentrações de 2,8 a 4,0 dag kg-1 como adequadas para as lâminas foliares de kiwi 'Hayward'. CRESSWELL (1985) apontou 2,0 a 4,0 dag kg-1 de cálcio como desejáveis em folhas de kiwi.

As concentrações de cálcio encontradas tanto nas folhas novas como nas velhas do tratamento "omissão de cálcio" classificam-se como muito baixas segundo esses autores.

As concentrações mais altas nas folhas foram encontradas no tratamento "omissão de potássio", o que pode ser explicado pela interação entre os cátions, cálcio e potássio, tendo sido favorecida a absorção desse último na ausència de competição com cálcio.

Foram encontradas altas concentrações de cálcio no tratamento "omissão de nitrogènio", as quais podem ser explicadas pelo efeito de diluição, tendo as poucas e pequenas folhas concentrado todo o cálcio nelas, enquanto as do tratamento "completo", maiores e mais numerosas, teriam diluído o nitrogènio absorvido. 
Na segunda coleta, nas folhas novas do cultivar Monty, a concentração de cálcio foi mais baixa no tratamento "omissão de cálcio", o qual só não diferiu significativamente dos tratamentos "omissão de nitrogênio" e "omissão de fósforo" (Tabela 13).

Nas folhas velhas desse cultivar, a concentração de cálcio foi menor no tratamento "omissão de cálcio", o qual diferiu significativamente dos tratamentos "omissão de magnésio" e "omissão de nitrogênio" (Tabela 14).

Nos ramos desse cultivar, a concentração de cálcio foi mais baixa no tratamento "omissão de cálcio", o qual diferiu significativamente dos tratamentos "testemunha" e "omissão de magnésio" (Tabela 15).

No conjunto das estacas e raizes, a concentração de cálcio foi mais baixa no tratamento "omissão de cálcio", que não diferiu significativamente de nenhum tratamento (Tabela 16)

CRESSWELL (1989) citou como adequadas as concentrações entre 2,0 e 4,0 dag kg-1 de cálcio, LALATTA (1985) apresentou como adequadas as concentrações entre 2,20 e 2,80 dag $\mathrm{kg}^{-1}$. SALE (1985) situou os limites adequados entre 3,0 e 4,0 dag $\mathrm{kg}^{-1}$ e BATTELLI \& RENZI (1990) os situaram entre 2,8 e 4,0 dag $\mathrm{kg}^{-1}$.

As concentrações encontradas nesse experimento nas folhas dos tratamentos "omissão de cálcio" classificaram-se como baixas, e as encontradas no tratamento "completo" foram menores que as preconizadas como adequadas pelos autores. 
Nos dois tipos de folhas, as maiores concentrações foram encontradas nos tratamentos "omissão de potássio" e "omissão de magnésio", possivelmente por não ter ocorrido competição entre aqueles cátions e o cálcio.

\subsection{Concentração de magnésio}

Na primeira coleta, a concentração de magnésio nas folhas novas do cultivar Monty foi a menor no tratamento "omissão de magnésio", o qual só não diferiu significativamente apenas do tratamento "omissão de enxofre", tendo diferido significativamente de todos os outros tratamentos (Tabela 10).

Nas folhas velhas desse cultivar, a concentração de magnésio foi menor no tratamento "omissão de magnésio", o qual não diferiu significativamente dos tratamentos "testemunha" e "omissão de enxofre", tendo diferido de todos os demais (Tabela 11).

Nos ramos do cultivar Monty, a concentração de magnésio foi menor no tratamento "omissão de magnésio", porém não diferiu significativamente de nenhum tratamento (Tabela 12).

Tanto nas folhas novas como nas folhas velhas, as concentrações de magnésio nos tratamentos "omissão de magnésio" e "completo" estão coerentes com a literatura, classificando-se como baixa e adequada respectivamente. Também nos dois tipos de folhas, as maiores concentrações ocorreram nos tratamentos "omissão de potássio" e "omissão de cálcio", possivelmente devido às suas interações com os cátions cálcio e magnésio, favorecendo-lhes a absorção na ausência de magnésio. 
Quanto à segunda coleta, nas folhas novas do cultivar Monty, a concentração de magnésio foi mais baixa no tratamento "omissão de magnésio", o qual diferiu significativamente dos tratamentos "omissão de potássio", "omissão de cálcio" e "omissão de enxofre" (Tabela 13).

Nas folhas velhas desse cultivar, a concentração de magnésio foi menor no tratamento "omissão de magnésio", o qual diferiu significativamente do tratamento "omissão de potássio"(Tabela 14).

Nos ramos do cultivar Monty, a concentração de magnésio foi menor no tratamento "omissão de magnésio", o qual diferiu significativamente do tratamento "omissão de potássio" (Tabela 15).

No conjunto das estacas e raizes desse cultivar, a concentração de magnésio foi menor no tratamento "omissão de magnésio", o qual diferiu significativamente dos tratamentos "omissão de enxofre" e "omissão de cálcio" (Tabela 16).

As concentrações encontradas nas folhas do tratamento "omissão de magnésio" classificaram-se como baixas segundo BATTELLI \& RENZI (1990), SALE (1985), LALATTA (1985) e CRESSWELL (1989). As encontradas no tratamento "completo" classificaram-se como adequadas e as maiores concentrações, encontradas nos tratamentos "omissão de potássio" e "omissão de cálcio" podem ser devidas à ausência de competição entre esses cátions e o magnésio. 


\subsection{Concentração de enxofre}

Os resultados da primeira coleta mostraram que nas folhas novas de kiwi cultivar Monty, a concentração de enxofre foi menor no tratamento "omissão de enxofre", o qual diferiu signifícativamente dos tratamentos "omissão de cálcio", "omissão de magnésio", "completo" e "omissão de potássio" (Tabela 10). Nas folhas velhas desse cultivar, a concentração de enxofre foi menor no tratamento "omissão de enxofre", o qual não diferiu significativamente dos tratamentos "testemunha" e "omissão de nitrogènio", tendo diferido significativamente dos demais tratamentos (Tabela 11).

Nos ramos desse cultivar, a concentração de enxofre foi mais baixa no tratamento "omissão de enxofre", o qual diferiu significativamente dos tratamentos "omissão de fósforo", "completo" e "omissão de magnésio" (Tabela 12).

SALE (1985) apresentou, como adequados, os valores entre $0,15 \mathrm{e}$

$0,3{\mathrm{dag} \mathrm{kg}^{-1}}^{-1}$ de concentração de enxofre no material seco das folhas completas de kiwi; CRESSWELL (1989) citou como indicadores de deficiència em enxofre, os valores menores que $0,2 \mathrm{dag} \mathrm{kg}^{-1}$ e como desejáveis, os valores entre 0,25 e $0,45 \mathrm{dag} \mathrm{kg}^{-1}$.

Os valores encontrados nos dois tipos de folhas para os tratamentos "omissão de enxofre" e "completo" concordam com os de SALE (1985) como muito baixo e adequado respectivamente, e são ambos considerados baixos de acordo com CRESSWELL ( 1989).

Em relação à segunda coleta de plantas no cultivar Monty, tanto nas folhas novas como nas velhas, nos ramos como nas estacas e raizes, não houve diferença significativa entre os tratamentos quanto à concentração de enxofre (Tabelas 13 a 16). 
Nas folhas novas não houve material suficiente para a análise nos tratamentos "omissão de nitrogênio", "testemunha" e "omissão de potássio" (Tabela 13); e nos ramos não houve material suficiente nos tratamentos "testemunha", "omissão de nitrogênio" e "omissão de enxofre" (Tabela 15).

De acordo com SALE (1985), as concentrações de enxofre entre 0,15 e 0,30 dag $\mathrm{kg}^{-1}$ são adequadas em folhas de kiwi e, de acordo com CRESSWELL (1989), são adequadas as concentrações entre 0,25 e $0,45 \mathrm{dag} \mathrm{kg}^{-1}$, também nas folhas completas.

Se forem considerados os valores propostos por SALE (1985), os valores encontrados neste experimento nas folhas novas e velhas podem ser indicados como adequados ou normais.

\subsubsection{Concentrações em plantas normais e em plantas com deficiência}

Em plantas normais (do tratamento "completo") e na fase juvenil da planta, na primeira colheita, as folhas novas apresentaram teores de N, P, K, Ca, Mg e S de 1,$83 ; 0,17 ; 1,07 ; 1,26 ; 0,39$ e 0,16 dag $\mathrm{kg}^{-1}$ no cultivar Bruno e de 2,$43 ; 0,20 ; 1,84$; 1,$25 ; 0,38 ; 0,16 \mathrm{dag} \mathrm{kg}^{-1}$ no cultivar Monty respectivamente. Por outro lado, em plantas sob condições de carência do nutriente, na fase de formação da planta e na primeira colheita realizada, as folhas novas apresentaram teores de $\mathrm{N}, \mathrm{P}, \mathrm{K}, \mathrm{Ca}, \mathrm{Mg}$ e S

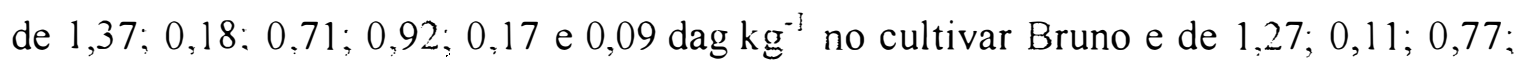
0,$67 ; 0,14$ e $0,07 \mathrm{dag} \mathrm{kg}^{-1}$ no cultivar Monty respectivamente. 
As plantas normais e na fase juvenil da planta, na primeira colheita, apresentaram, nas folhas velhas, teores de N, P, K, Ca, Mg e S de 2,47; 0,18; 1,34; 1,71; 0,40 e 0,13 dag kg $^{-1}$ no cultivar Bruno e de 2,$25 ; 0,15 ; 1,40 ; 1,48 ; 0,40$ e 0,14 dag $\mathrm{kg}^{-1}$ no cultivar Monty respectivamente. Essas plantas sob condições de carência do nutriente, na fase de formação da planta e na primeira colheita realizada, apresentaram, nas folhas velhas, teores de N,P, K, Ca, Mg e S de 1,50;0,14;0,30;1,06;0,22 e $0,09 \mathrm{dag} \mathrm{kg}^{-1}$ no cultivar Bruno e de 1,$22 ; 0,09 ; 0,47 ; 0,79 ; 0,14$ e $0,12 \mathrm{dag} \mathrm{kg}^{-1}$ no cultivar Monty respectivamente.

\subsubsection{Sintomatologia das deficiências}

\subsubsection{Nitrogênio}

Cinco dias após o início do fornecimento da solução com omissão de nitrogènio, foram observados os primeiros sintomas de deficiència desse nutriente no cultivar Monty. As folhas superiores tornaram-se verde bem claro, quase amarelo esbranquiçadas. Très dias após, todas as folhas apresentavam-se cloróticas, começando a amarelar principalmente nos bordos. Em trinta dias, ocorreram manchas necróticas no limbo das folhas mais velhas, coalescendo em seguida. Mais tarde, as margens das folhas mais velhas necrosaram, rasgando-se. Finalmente, ocorreu a queda das folhas velhas.

Todas as plantas deste tratamento tiveram seu crescimento afetado: alèm de curtas, apresentavam tanto brotações como pecíolos foliares mais finos, além de folhas menos espessas, muito delgadas e pequenas e de cor verde muito clara. 
Quanto ao peso do material seco das folhas novas, este foi a metade em plantas no tratamento "omissão de nitrogênio", quando comparado com os resultados obtidos em plantas do tratamento "completo", para os dois cultivares e nas duas coletas.

O peso do material seco das folhas velhas foi quatro vezes menor na primeira coleta e cinco vezes menor na segunda coleta, para o cultivar Bruno, quando as plantas sofreram omissão de nitrogênio, comparado com aquele encontrado em plantas do tratamento "completo".

Para o cultivar Monty, o peso do material seco das folhas velhas foi a metade na primeira coleta e cerca de sete vezes menor na segunda coleta, quando as plantas estiveram sob o tratamento "omissão de nitrogênio", comparado com os resultados obtidos em plantas do tratamento "completo".

Para ambos os cultivares e para as duas coletas, o peso do material seco de ramos foi seis vezes menor no tratamento "omissão de nitrogênio", quando comparado com os resultados obtidos em plantas do tratamento "completo".

Nas folhas em geral, ocorreu o seguinte: os bordos das folhas tornavam-se esbranquiçados antes da região das nervuras, permanecendo as nervuras foliares verdes por mais tempo. Em seguida, a ponta das folhas e depois as margens apresentavam-se marrom-avermelhadas, enrolando-se em seguida. $O$ secamento progrediu atingindo toda a folha, que caiu em seguida. As folhas inferiores eram as primeiras a necrosar e cair (Figuras 1 e 2). Continuavam a nascer e crescer folhas novas, porém mantinham-se menores que as do tratamento "completo". 
As plantas tiveram seus ramos e folhas colhidos, pela primeira vez. setenta e sete dias após o início dos tratamentos. Após essa poda, as plantas que sofreram omissão de nitrogênio revelaram-se muito atrasadas no seu desenvolvimento e, em seguida, as folhas passaram a brotar em tufos na mesma gema, não formando ramos.

As folhas eram verde-claro-amareladas, esbranquiçando-se nas margens e, em seguida, elas se tornaram marrom-avermelhadas. O secamento iniciava-se pela ponta, progredindo para as adjacências e o limbo. Seguia-se a queda das folhas velhas. Antes do final do experimento, as plantas deste tratamento apresentavam raizes apodrecidas.

\subsubsection{Potássio}

Vinte e quatro dias após o início dos tratamentos, apareceram sintomas de carência de potássio nas plantas do cultivar Bruno. Iniciaram-se manchas marrons entre as nervuras das folhas inferiores ou mais velhas, que antes se tornaram verde esmaecido.

De uma forma geral, as manchas marrons iniciaram-se ao lado da nervura principal, próximo ao ponto de inserção da folha e coalesceram em seguida. Essa parte manchada se tornou mais delgada e visivel nas duas faces do limbo foliar; em seguida, as folhas secaram e enrolaram-se para cima. O ponto de inserção e as nervuras permaneciam verdes, até a queda das folhas. Isso ocorria nas folhas inferiores, permanecendo as superiores verdes por mais tempo (Figura 3). 
Após a primeira colheita da parte aèrea, deixou-se que as plantas rebrotassem e, as com carència de potássio mostraram-se atrasadas na formação de ramos, que em algumas plantas eram quase inexistentes.

Algumas folhas murchavam com facilidade e tornaram a surgir as manchas e os secamentos descritos na primeira etapa desse experimento. As folhas da maior parte das plantas caíram antes do final da segunda etapa do experimento.

O peso do material seco das folhas novas para o cultivar Bruno nas plantas sob condições de carência de potássio foi cerca de metade daquele encontrado nas plantas do tratamento "completo", para a primeira coleta e, cerca da terça parte do encontrado no tratamento "completo", para a segunda coleta.

O peso do material seco das folhas velhas neste cultivar foi cerca de um terço menor nas plantas sob carência de potássio, comparado com aquele encontrado nas do tratamento "completo", na primeira coleta, e, cerca de um terço do valor encontrado no tratamento "completo", por ocasião da segunda coleta; ainda para este cultivar, o peso do material seco de ramos foi a metade daquele encontrado nas plantas sob tratamento "completo".

Para o cultivar Monty, o peso do material seco das folhas novas e velhas e dos ramos e conjunto estacas e raízes foi sempre a metade nas plantas sob tratamento "omissão de potássio" quando comparadas com aquelas sob tratamento "completo". 


\subsubsection{Magnésio}

Foram observadas manchas cloróticas entre as nervuras, as quais se desenvolveram e se uniram, dando a impressão de listras amareladas entre as nervuras verdes em plantas de cultivar Monty. Esses sintomas foram persistentes.

Os pesos do material seco das folhas novas e velhas e dos ramos foram cerca de metade nas plantas sob o tratamento "omissão de magnésio" por ocasião da segunda coleta, para ambos os cultivares. Não se notaram alterações por ocasião da primeira coleta.

\subsubsection{Enxofre}

Em plantas com carência de enxofre, ocorreu clorose de folhas superiores novas, além da perda do brilho do limbo, enquanto as folhas velhas permaneciam verde-escuras. Houve queda das folhas.

Após a colheita de folhas e ramos, no final da primeira etapa do experimento, quando foram então deixadas rebrotar, as plantas desse tratamento mostraram-se atrasadas no seu desenvolvimento.

Novamente ocorreu clorose de folhas novas e queda das mesmas, havendo plantas em que a queda das folhas foi total. Algumas plantas foram colhidas antes do final do experimento, com raizes enegrecidas. 
Os pesos do material seco de folhas novas e velhas de plantas do cultivar Monty no tratamento "omissão de enxofre" foram cerca de metade daqueles encontrados nas plantas do tratamento "completo", na primeira coleta.

O peso do material seco de ramos em plantas desse cultivar sob condições de carência de enxofre foi cerca de um terço daquele encontrado em ramos de plantas sob tratamento "completo", na primeira coleta.

\subsubsection{Testemunha}

As plantas que receberam apenas micronutrientes apresentaram folhas mais novas com coloraçào verde-clara pálida, inicialmente menos pálida que as que sofreram omissão de nitrogênio. Em seguida, as folhas do terço inferior apresentaram as margens amareladas, com lesões marrom-escuras nas margens, as quais depois coalesceram (Figuras 1 e 2).

As plantas formaram ramos mais finos, e embora tenham continuado a formar ramos após a primeira coleta, a partir desta, as folhas passaram a se formar em tufos, não crescendo muito.

A principal diferença em relação ao tratamento "omissão de nitrogênio" é que no tratamento "testemunha" houve formação de ramos, mesmo após a poda realizada na primeira coleta. As plantas também apresentavam folhas de tamanho reduzido, verde-claras e, finalmente, marrom-avermelhadas e o crescimento da planta foi retardado. As raizes eram abundantes, mas com raizes novas finas. 
O peso do material seco das folhas novas de plantas sob o tratamento "testemunha" foi cerca de um quinto daquele encontrado em plantas sob o tratamento "completo" para o cultivar Bruno. O peso do material seco de folhas velhas foi cerca de um terço e o peso de material seco de ramos foi sessenta por cento menor quando as plantas estavam submetidas ao tratamento "testemunha" comparadas com as plantas do tratamento "completo", para o cultivar Bruno, na primeira coleta.

Por ocasião da segunda coleta, ainda para este cultivar, o peso do material seco de folhas novas foi quarenta e dois por cento menor que o encontrado em plantas do tratamento "completo" e o de folhas velhas foi cinqüenta por cento menor em plantas sob tratamento "testemunha" em comparação com plantas do tratamento "completo".

Para o cultivar Monty, o peso do material seco de folhas novas foi cerca de treze por cento em plantas do tratamento "testemunha", comparado com o encontrado em plantas do tratamento "completo": o peso do material seco de folhas velhas de plantas, nessas mesmas condições, foi cerca de vinte e cinco por cento daquele encontrado em plantas do tratamento "completo" e, o peso do material seco de ramos de plantas sob tratamento "testemunha" foi quatorze por cento do valor encontrado em ramos de plantas do tratamento "completo", por ocasião da primeira coleta. O peso do material seco das folhas novas foi cerca de cinqüenta por cento menor quando as plantas estavam no tratamento "testemunha", comparado com peso encontrado em plantas sob o tratamento "completo"; o peso do material seco das folhas velhas foi cerca de dezenove por cento daquele encontrado em plantas do tratamento "completo" e, o peso de ramos foi cerca de vinte e cinco por cento em plantas do tratamento "testemunha" em comparaçào com o encontrado em plantas do tratamento "completo", por ocasião da segunda coleta. 

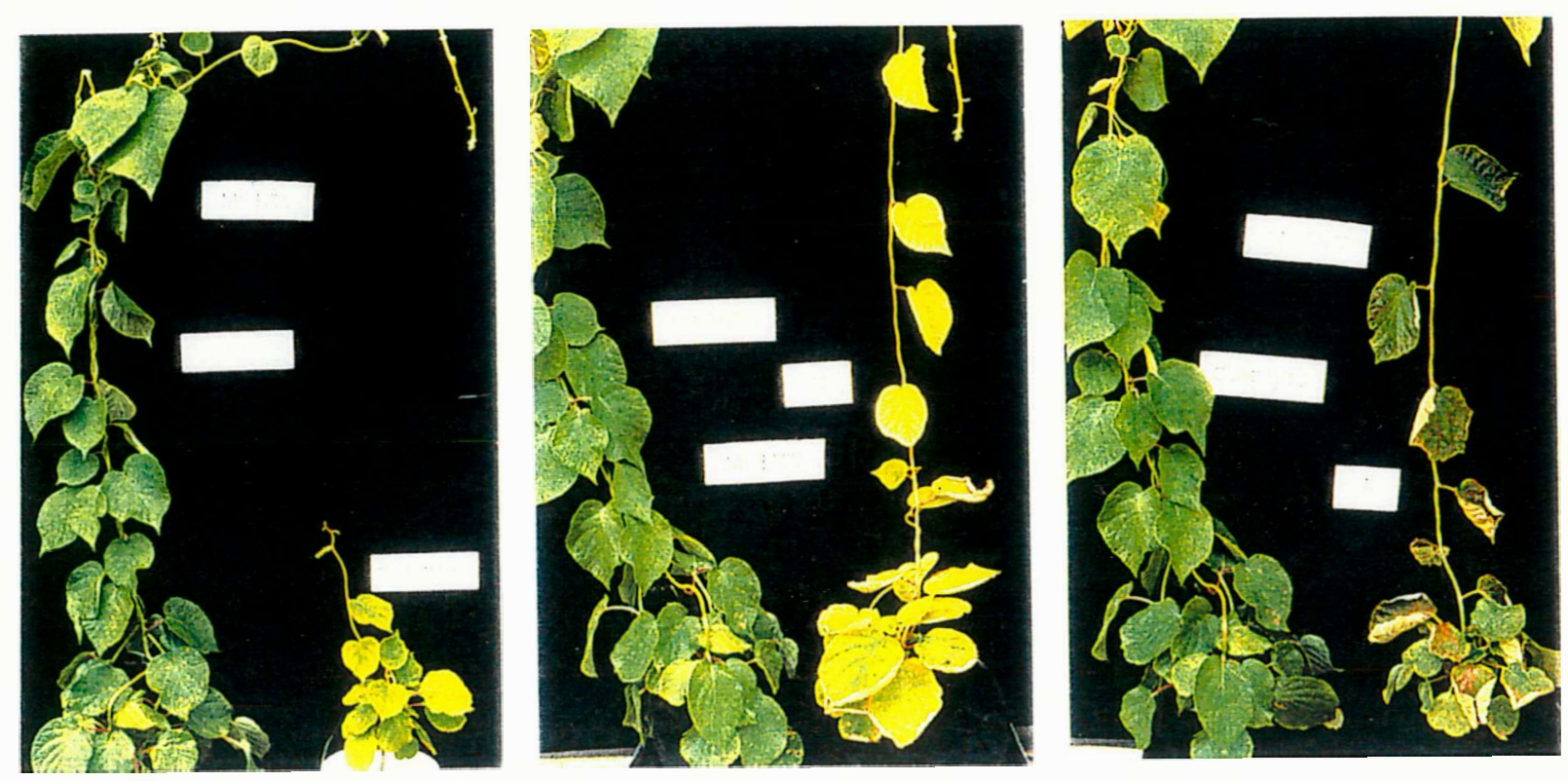

Figura 1 - Sintomas de deficiência em kiwi cultivar Monty dos tratamentos Testemunha, Omissão de Nitrogênio e Omissão de Potássio. 

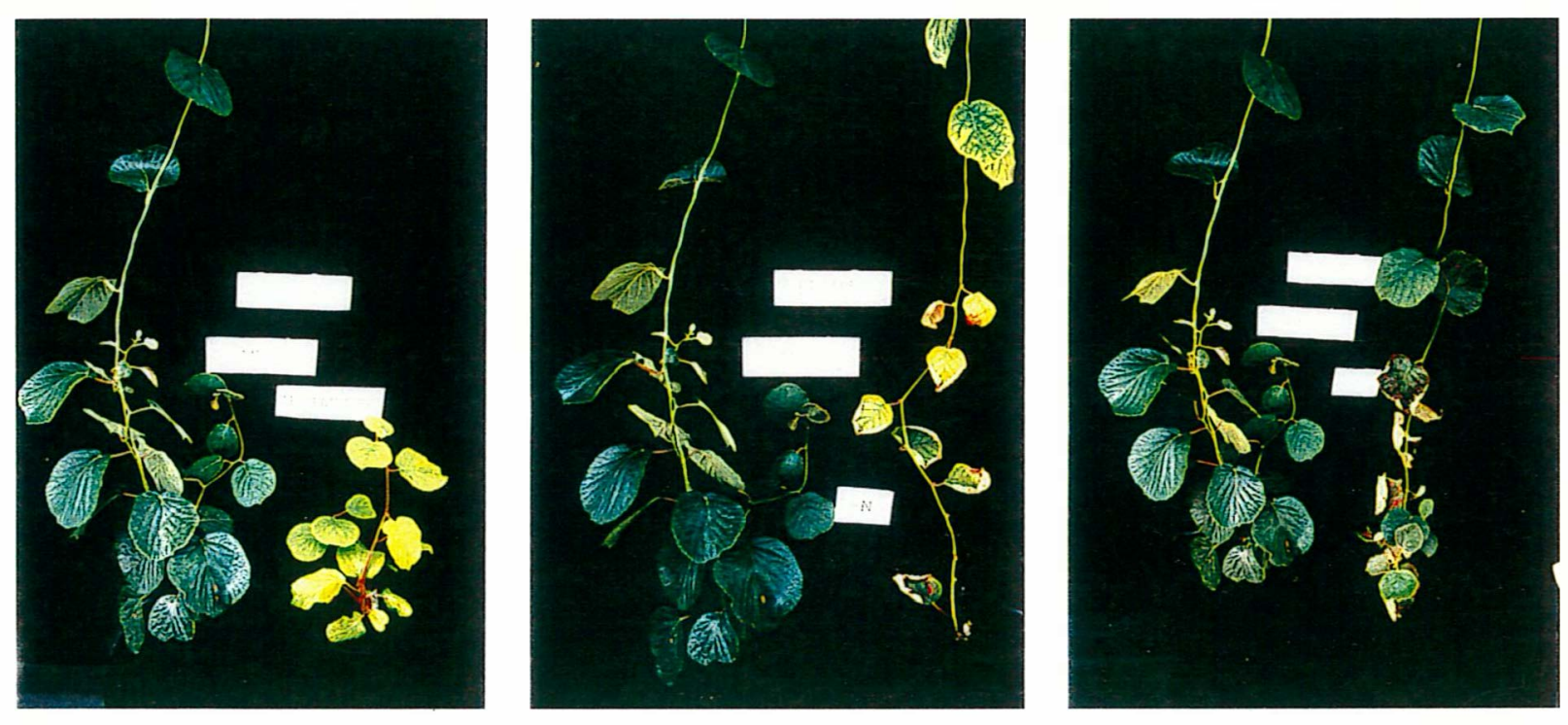

Figura 2 - Sintomas de deficiência em kiwi cultivar Bruno dos tratamentos Testemunha, Omissão de Nitrogênio e Omissão de Potássio. 


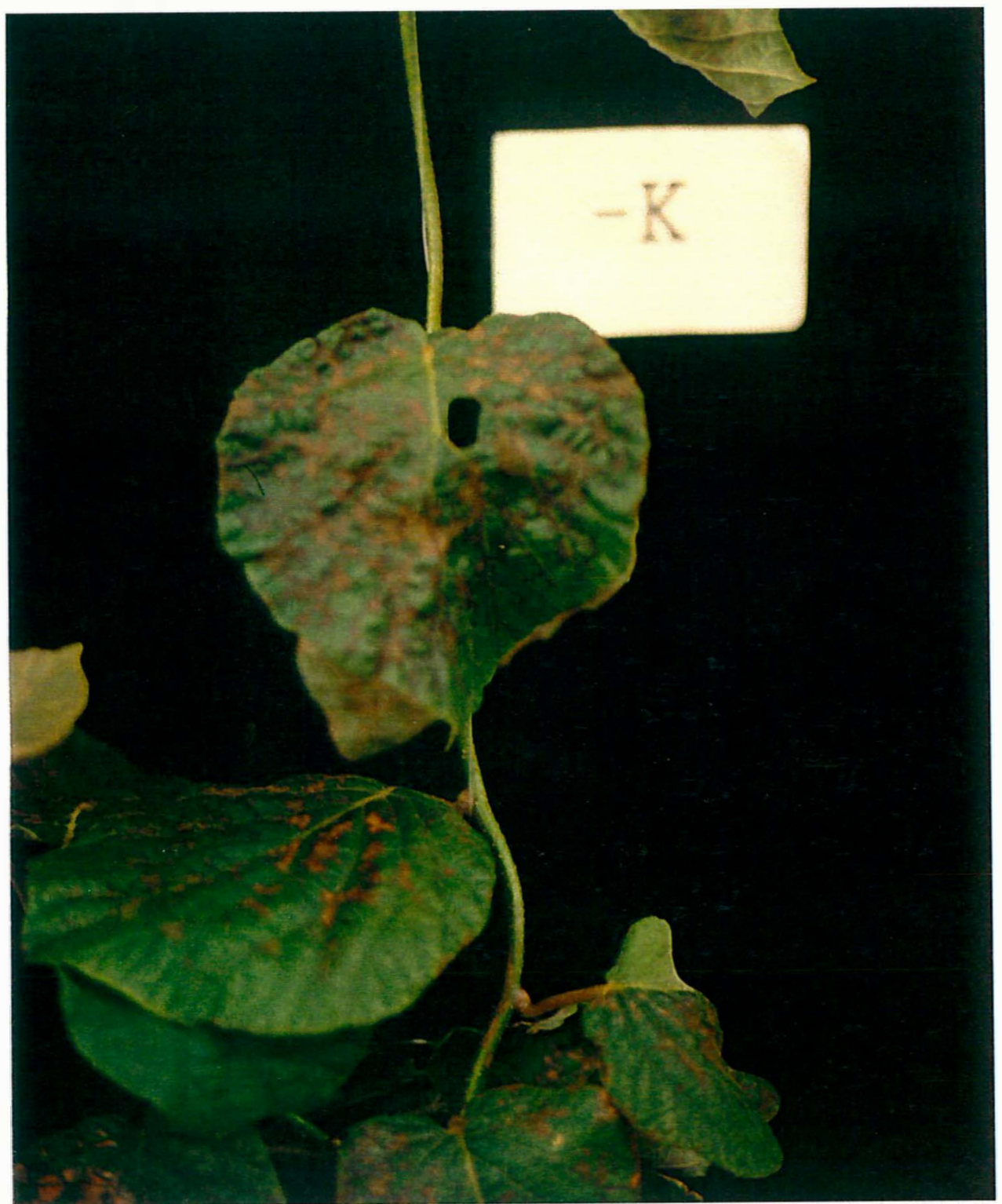

Figura 3 - Sintomas de deficiência de potássio em kiwi cultivar Bruno. 


\subsection{Experimento no campo}

\subsubsection{Evolução do peso do material seco dos frutos}

Quanto ao peso médio do material seco, o cultivar Monty apresentou,

inicialmente, frutos com 0,507 g e, no final do ciclo, com 20,414 g; o cultivar Bruno,

por sua vez, apresentou frutos com 0,366 g e 18,071 g, no inicio e no final do ciclo respectivamente (Figura 4 ).

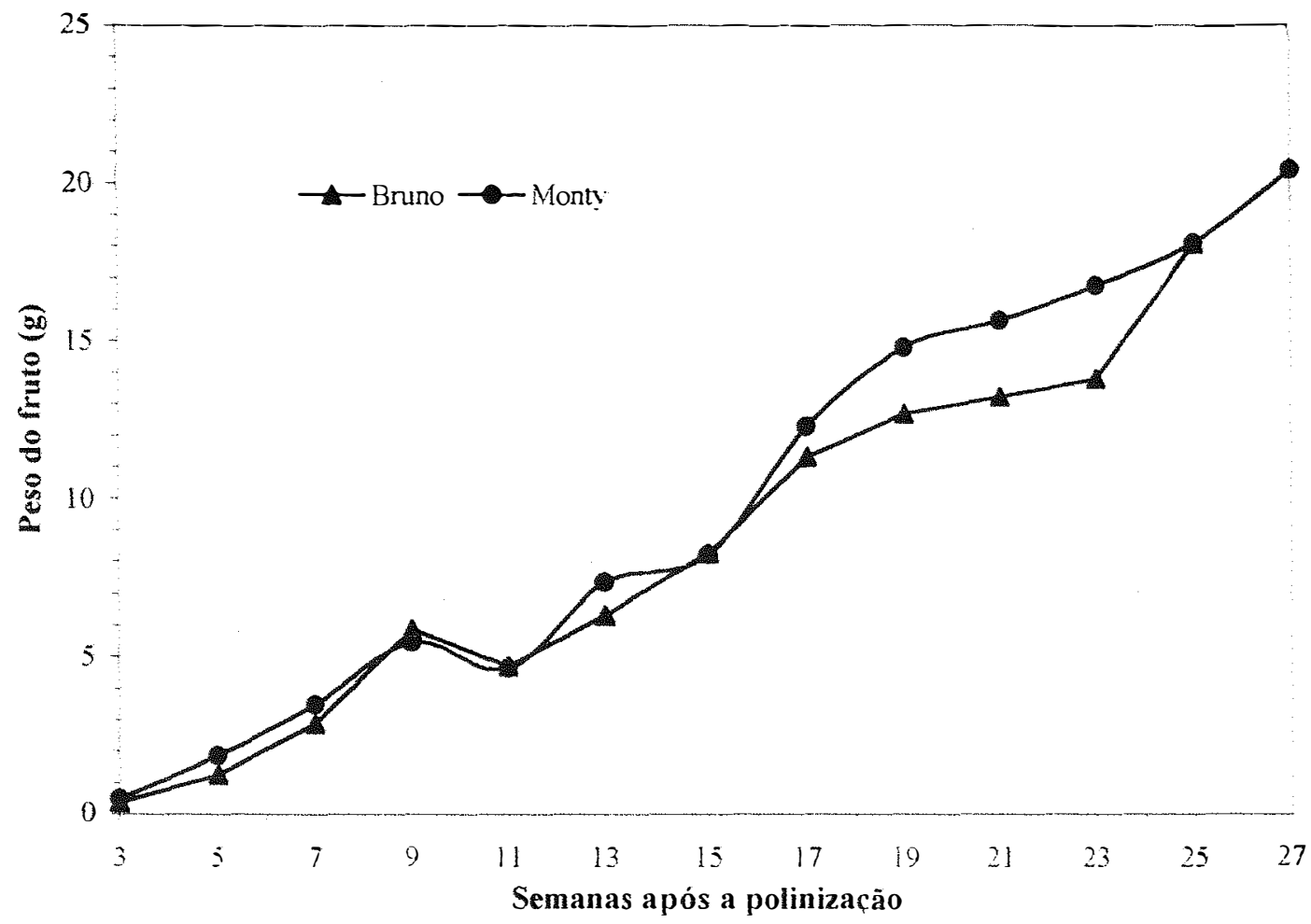

Figura 4. Peso individual de frutos dos cultivares Bruno e Monty de kiwi, nas épocas de amostragem, no experimento de campo. 


\subsubsection{Evolução do comportamento dos macronutrientes}

\subsubsection{Nitrogênio}

A concentração de nitrogènio nas folhas amostradas decresceu em ambos os cultivares, do início até o final do período de amostragem, apresentando, apenas no cultivar Monty, ligeiro acréscimo entre a penúltima e última época de amostragem. No cultivar Monty, ocorreu também certa estabilidade de valores entre a primeira e a terceira época, iniciando o decréscimo somente após a terceira época de amostragem ou sétima semana (Figura 5).

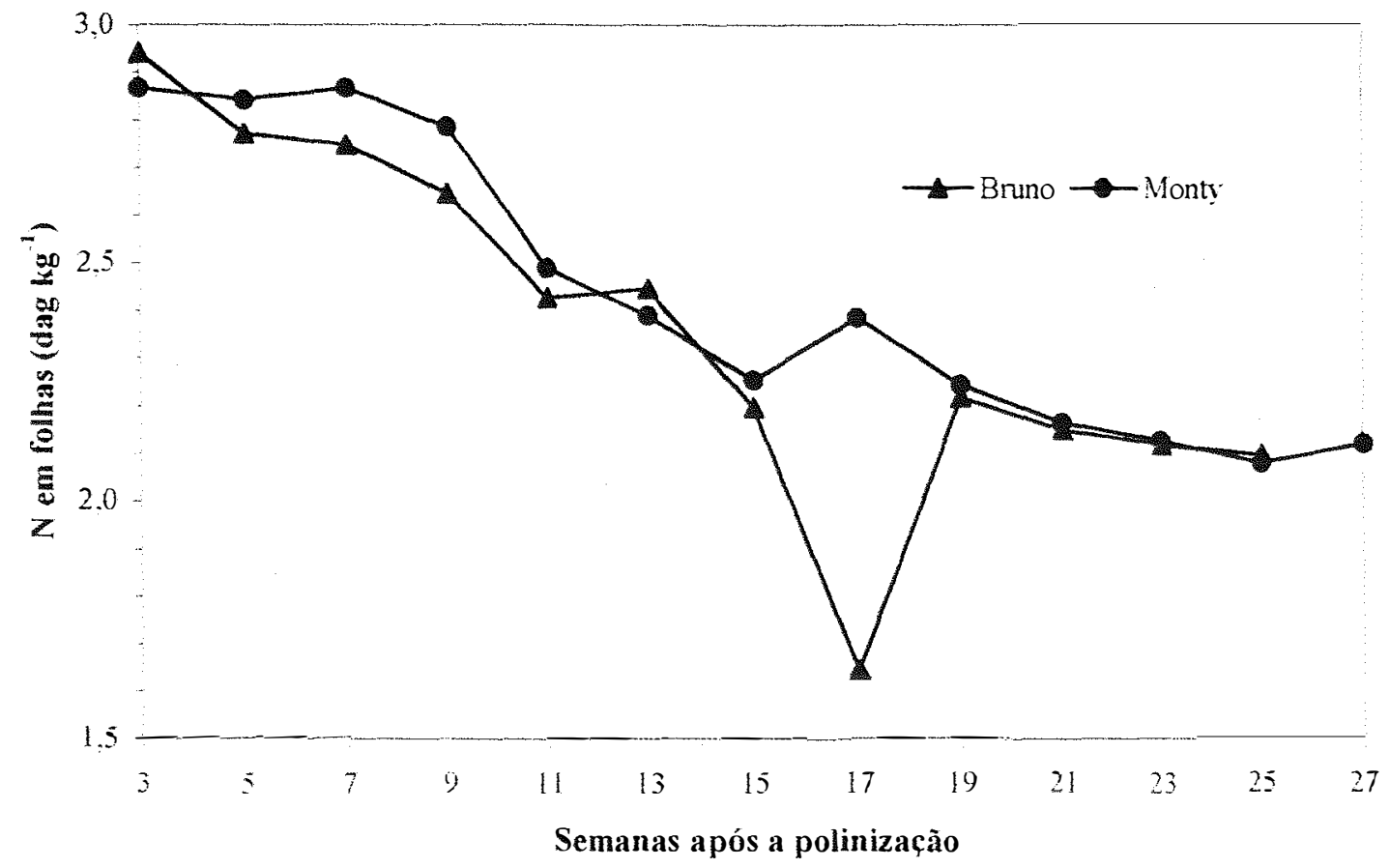

Figura 5. Concentração de nitrogênio nas folhas nos cultivares Bruno e Monty de kiwi, nas épocas de amostragem, no experimento de campo. 
Os teores de nitrogênio nos frutos de ambos os cultivares, de uma forma geral, decresceram em relação ao início da frutificação (teores iniciais: $1,814 \mathrm{dag} \mathrm{kg}^{-1}$ para 'Bruno' e 1,873dag $\mathrm{kg}^{-1}$ para 'Monty'), tendo ocorrido elevações em ambos os cultivares entre a quinta e sexta época de amostragem, correspondentes à décima primeira e décima terceira semanas (teores respectivamente $1,160 \mathrm{dag} \mathrm{kg}^{-1} \mathrm{e}$ $1,276 \mathrm{dag} \mathrm{kg}^{-1}$ para 'Bruno' e 1,414 dag kg ${ }^{-1}$ e 1,626 dag kg ${ }^{-1}$ para 'Monty') e entre a penúltima e última época de amostragem em cada cultivar (teores $0,820 \mathrm{dag} \mathrm{kg}^{-1} \mathrm{e}$ 1,040 dag kg ${ }^{-1}$ para 'Bruno' e 0,993 dag kg-1 e 1,214 dag kg-1 para 'Monty'. Enquanto o cultivar Monty apresentou queda linear no teor de nitrogênio entre a sétima e nona épocas de amostragem, no cultivar Bruno houve um aumento no teor de nitrogênio no fruto na oitava época, seguido de uma queda linear (Figura 6).

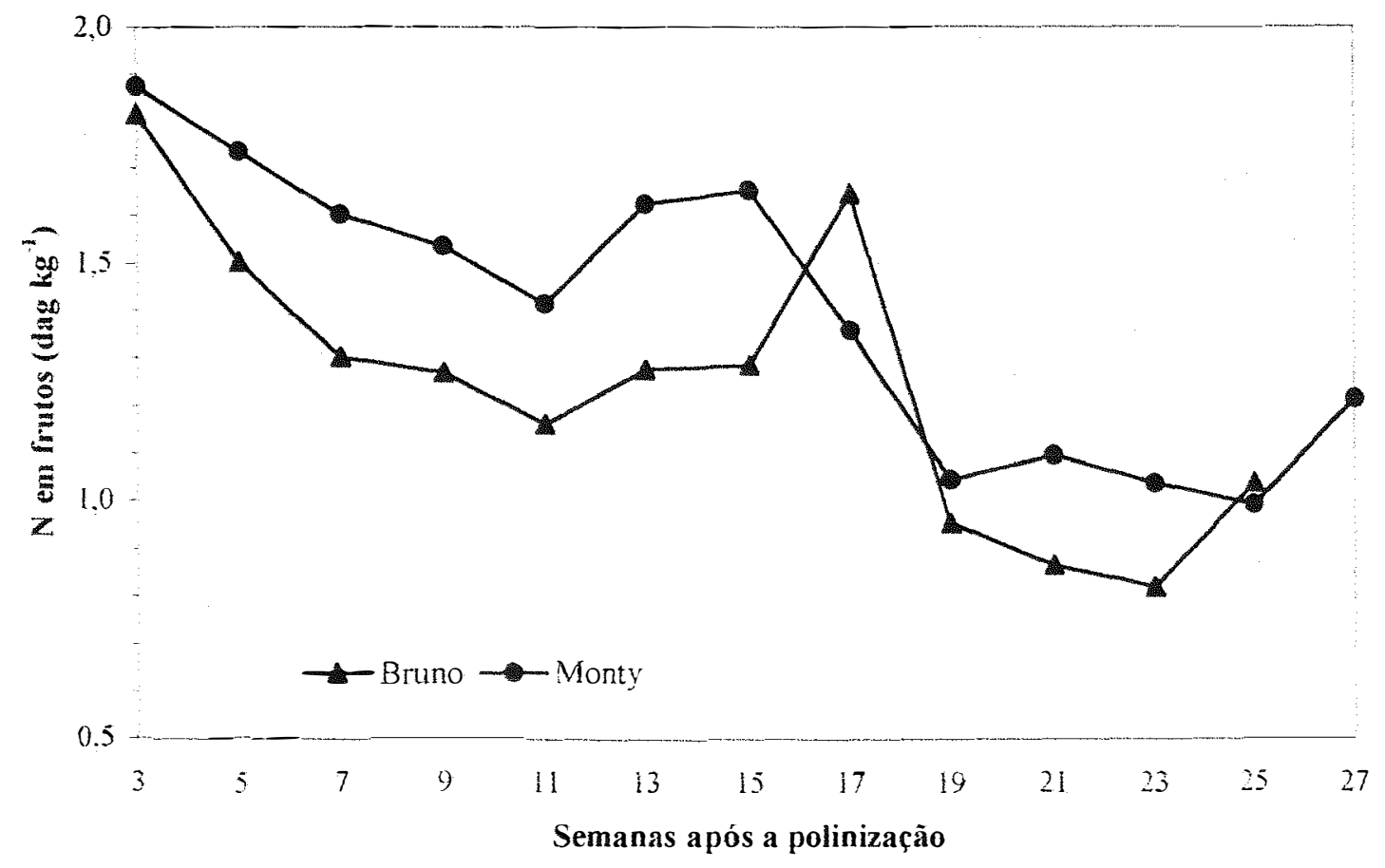

Figura 6. Concentração de nitrogênio nos frutos nos cultivares Bruno e Monty de kiwi, nas épocas de amostragem, no experimento de campo. 
A extração de nitrogènio pelos frutos teve seu valor mais baixo no início da amostragem, em ambos os cultivares, e seu valor mais alto na última amostragem, em cada cultivar (iniciais $6,658 \mathrm{mg} \mathrm{N}$ e $9,599 \mathrm{mg}$ de $\mathrm{N}$ e finais $187,406 \mathrm{mg}$ e $248,378 \mathrm{mg}$ de $\mathrm{N}$ para 'Bruno' e 'Monty' respectivamente). Houve aumento da extração entre a primeira e a quarta épocas, correspondentes à terceira e nona semanas $(6,658 \mathrm{mg}$ e 75,219 mg para 'Bruno' e 9,500 mg e 83,887 mg para 'Monty'), decréscimo entre a nona e a décima primeira semana, para ambos os cultivares, seguidos de elevações nas extrações. Os valores do cultivar Monty foram sempre superiores aos de 'Bruno', apenas na oitava época de amostragem, correspondente à décima sétima semana, os valores médios de 'Bruno' superaram os de 'Monty' (Figura 7).

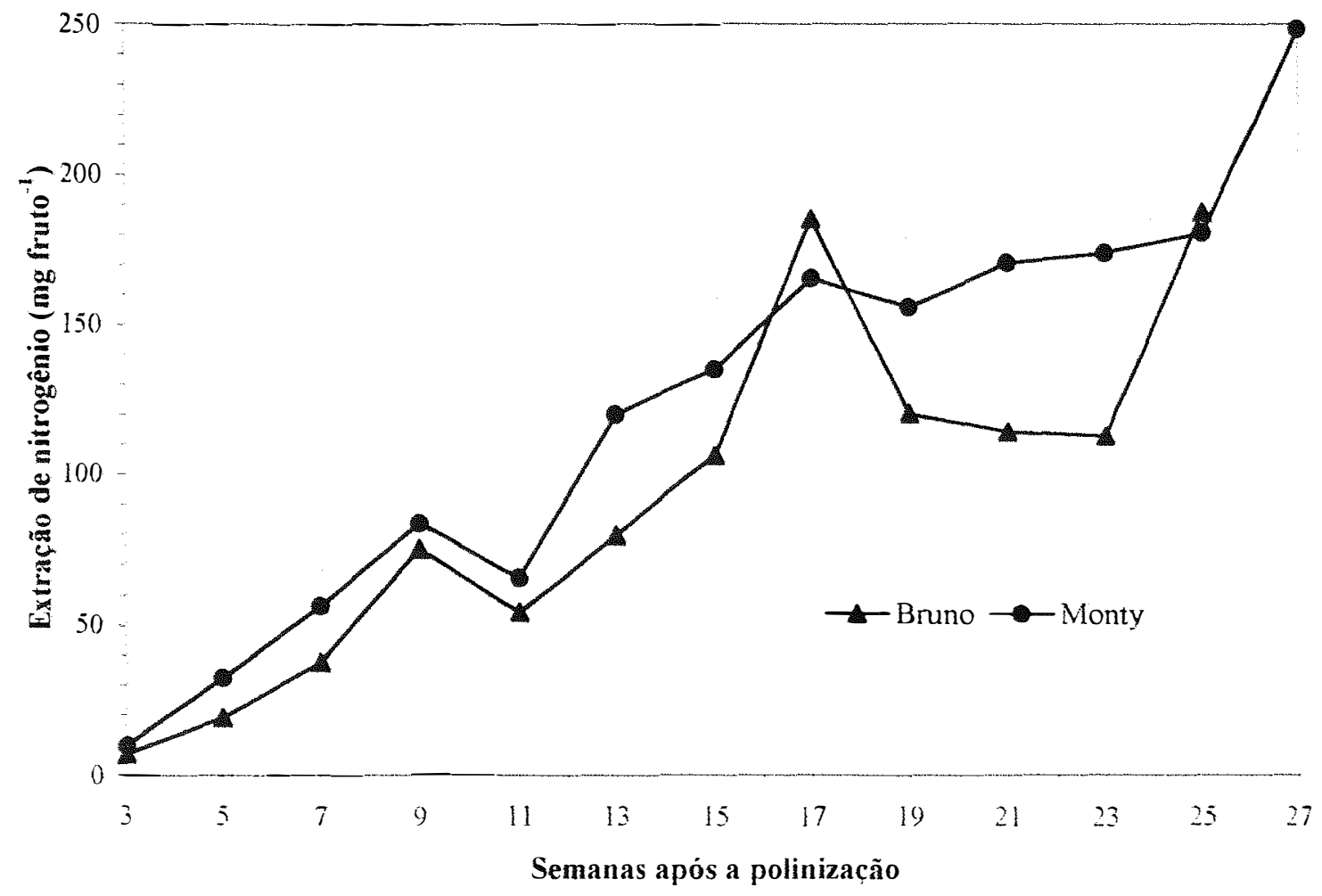

Figura 7. Extração de nitrogènio por frutos nos cultivares Bruno e Monty de kiwi, nas épocas de amostragem, no experimento de campo. 
O decréscimo da concentração de nitrogènio em folhas simultaneamente com o aumento dessa concentração em frutos na oitava época de amostragem sugere que tenha havido uma possivel translocação de nitrogênio das folhas para os frutos do cultivar Bruno, nessa época.

\subsubsection{Fósforo}

As concentrações de fósforo nas folhas foram, em geral, superiores no final das amostragens, se comparadas às do início, e os teores apresentados pelo cultivar Bruno foram, em média, superiores em relação ao cultivar Monty. Os valores médios mínimo e máximo foram $0,199 \mathrm{dag} \mathrm{kg}^{-1}$ e $0,259 \mathrm{dag} \mathrm{kg}^{-1}$ para 'Bruno' e $0,171 \mathrm{dag} \mathrm{kg}^{-1} \mathrm{e}$

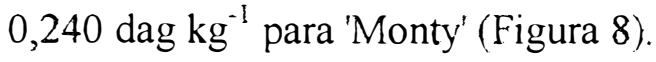

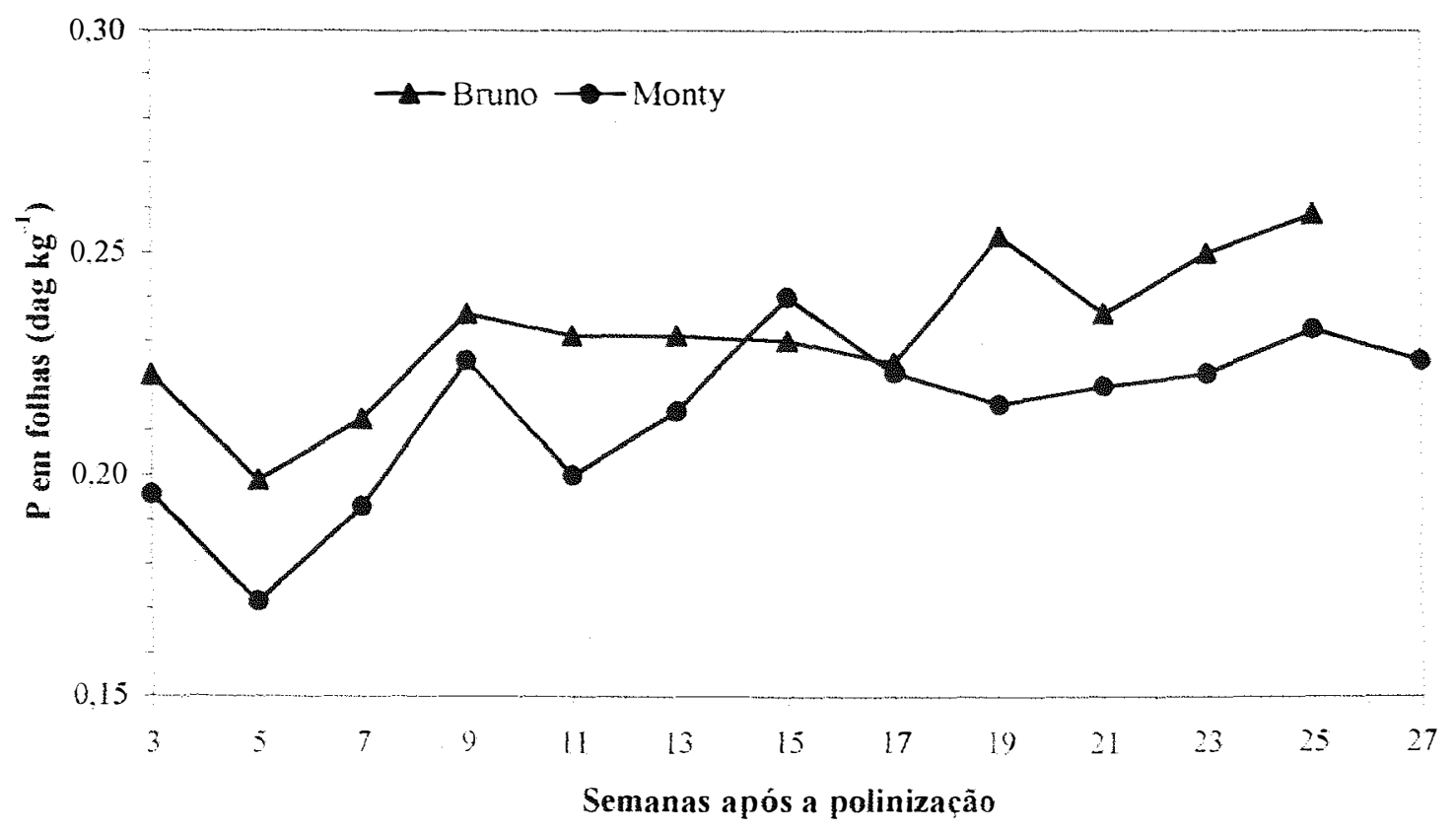

Figura 8. Concentração de fósforo nas folhas nos cultivares Bruno e Monty de kiwi, nas épocas de amostragem, no experimento de campo. 
As concentrações de fósforo nos frutos apresentaram-se, em relação ao periodo da amostragem, menores no final, tendo ocorrido uma elevação e posterior diminuição nos teores médios em frutos de 'Monty', na sexta época de amostragem ou décima terceira semana. Os teores em 'Bruno', nesta época, apresentaram-se estáveis até a décima quinta semana, a partir da qual diminuiram. Os maiores e menores valores médios encontrados foram: 0,283 $\mathrm{dag} \mathrm{kg}^{-1}$ e $0,156 \mathrm{dag} \mathrm{kg}^{-1}$ para 'Bruno' e 0,264 dag kg ${ }^{-1}$ e 0,166 dag kg ${ }^{-1}$ para 'Monty' (Figura 9).

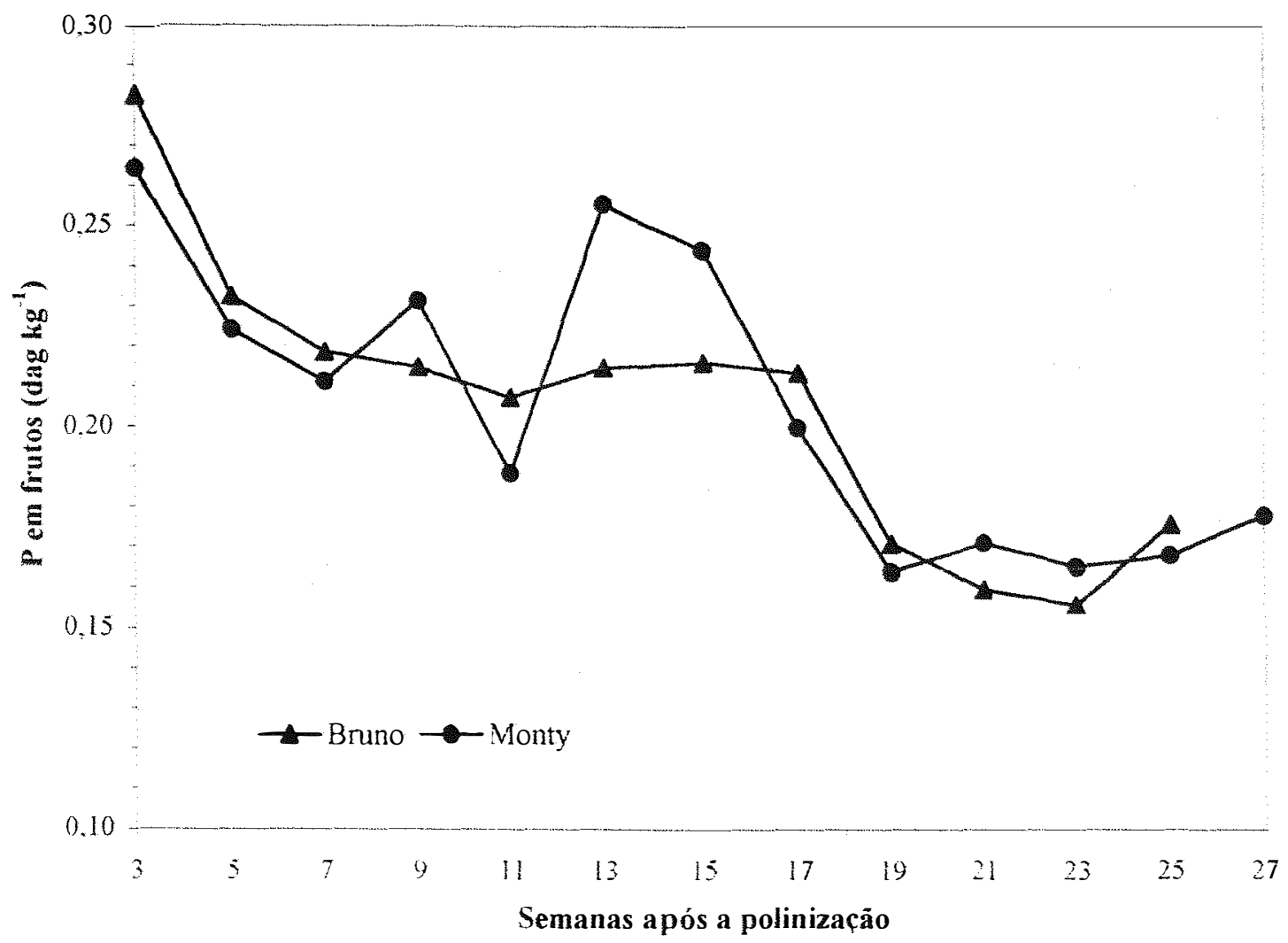

Figura 9. Concentração de fósforo nos frutos nos cultivares Bruno e Monty de kiwi, nas épocas de amostragem, no experimento de campo. 
A extraçào de fósforo por frutos foi, no geral, crescente do início ao fím do período de amostragem, tendo sido os valores encontrados para 'Monty' maiores do que os encontrados para frutos de 'Bruno'. Os menores e maiores valores médios encontrados, respectivamente, na primeira e última época de amostragem de cada cultivar foram: $1,033 \mathrm{mg}$ e 31,814 mg para 'Bruno' e 1,334 mg e 36,582 mg para 'Monty' (Figura 10).

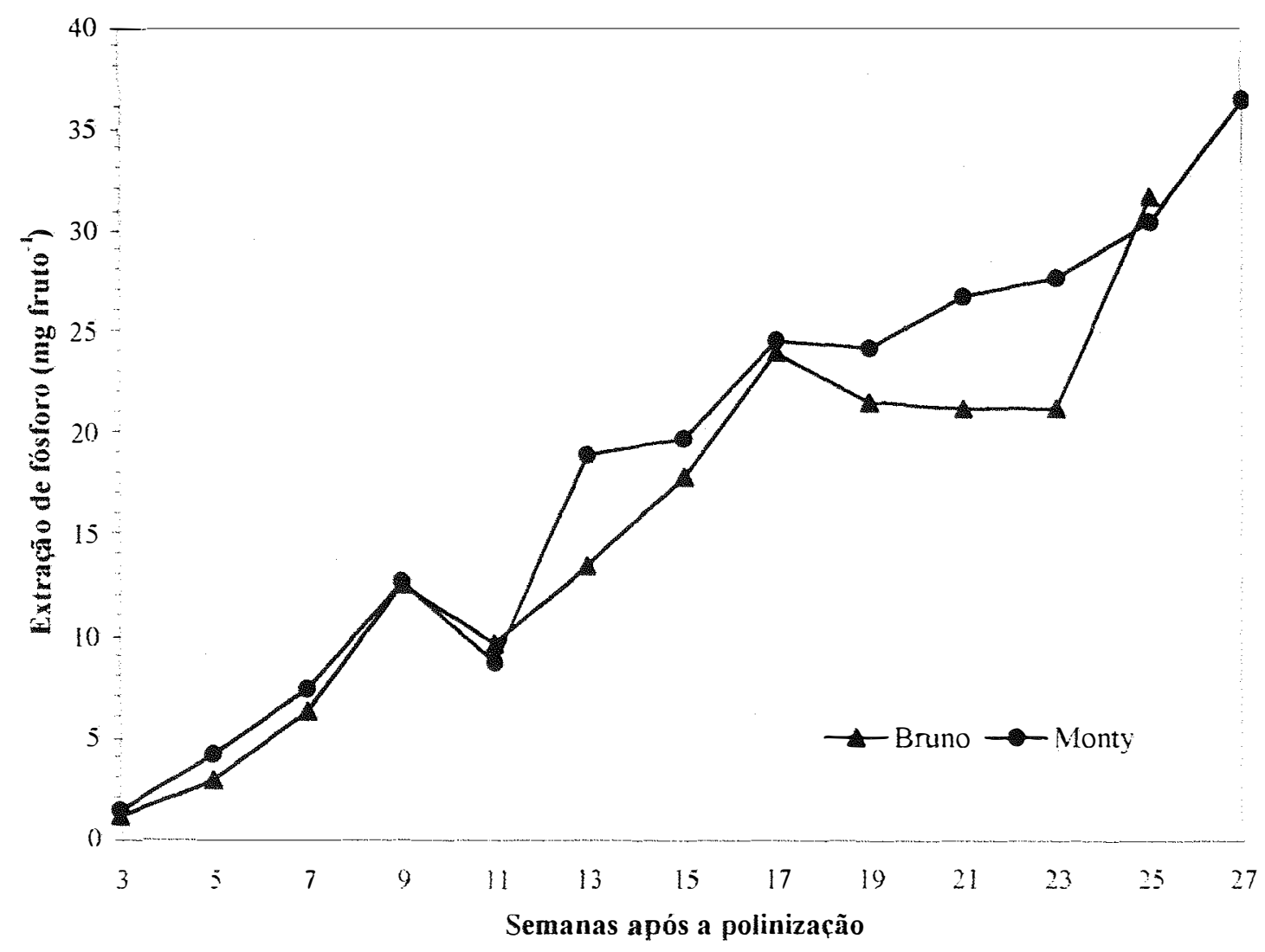

Figura 10. Extraçào de fósforo por frutos nos cultivares Bruno e Monty de kiwi, nas épocas de amostragem, no experimento de campo. 


\subsubsection{Potássio}

As concentrações de potássio nas folhas coletadas em ambos os cultivares seguiram tendências aproximadamente paralelas, salvo a elevação que, para 'Bruno', ocorreu na oitava época de amostragem e que, para 'Monty', só ocorreu na seguinte (semanas décima sétima e décima nona após a polinização). Os teores nas folhas de 'Monty' foram inferiores àqueles nas de 'Bruno' em todas as amostragens. O maior valor médio encontrado para 'Bruno' foi $2,573 \mathrm{dag} \mathrm{kg}^{-1}$ e o menor foi 1,858 dag kg-1, enquanto para 'Monty' foram de 2,319 dag kg-1 e $1,104 \mathrm{dag} \mathrm{kg}^{-1}$ respectivamente, tendo os primeiros de cada cultivar ocorrido no início das amostragens e os últimos e menores na última época de amostragem (Figura 11).

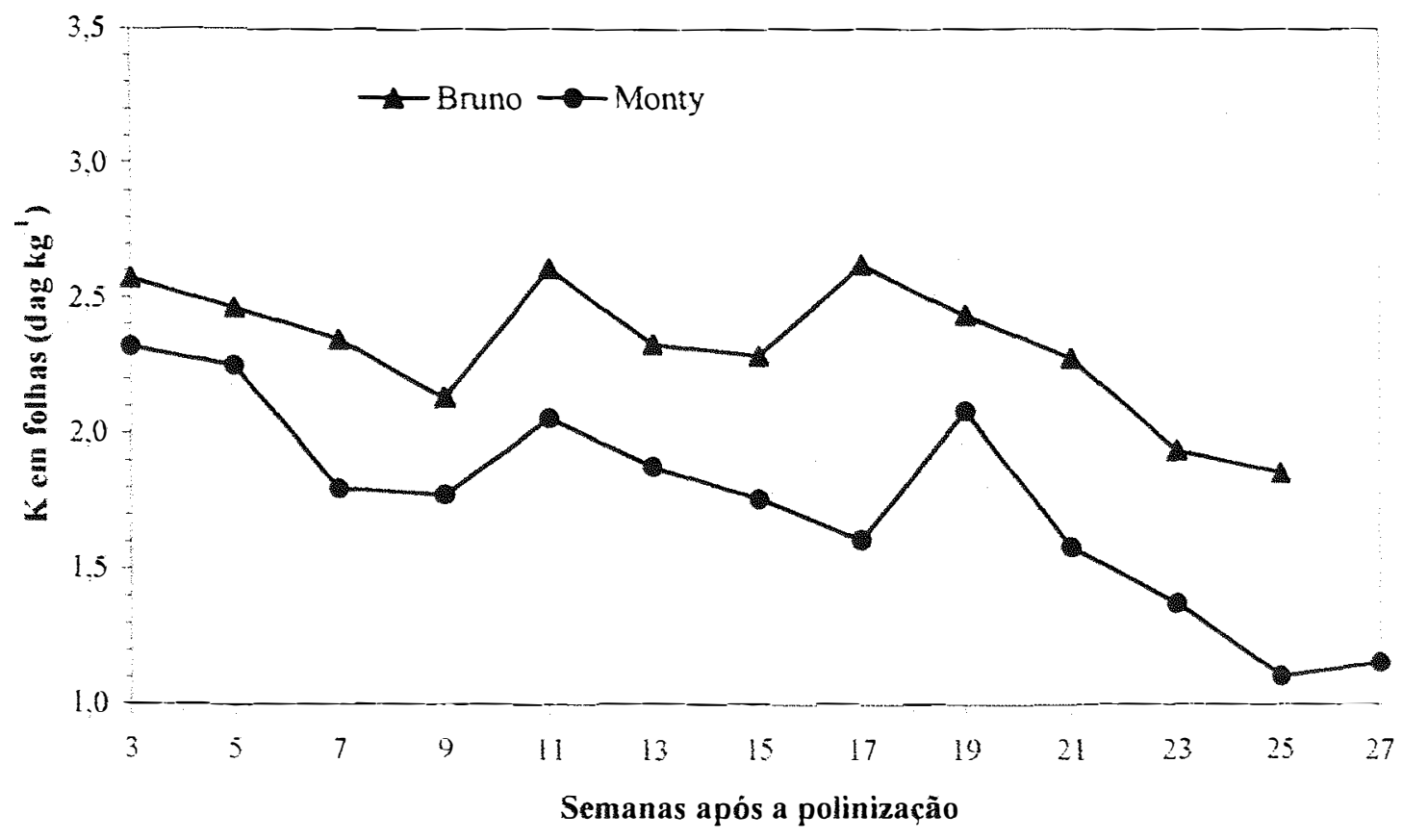

Figura 11. Concentração de potássio nas folhas nos cultivares Bruno e Monty de kiwi, nas épocas de amostragem, no experimento de campo. 
Quanto às concentrações de potássio em frutos, ocorreram tendências paralelas nas amostragens iniciais, e a partir da terceira época, os valores médios encontrados para 'Monty' superaram, em geral, os encontrados para 'Bruno'. Porém da vigésima terceira semana em diante os teores em frutos de 'Monty' se mostraram inferiores. Os maiores e menores valores médios encontrados para cada cultivar respectivamente foram: $3,121 \mathrm{dag} \mathrm{kg}^{-1}$ e 2,339 dag kg ${ }^{-1}$ para 'Bruno' e 3,107 dag kg-1 e 2,019 dag kg-1 para 'Monty' (Figura 12).

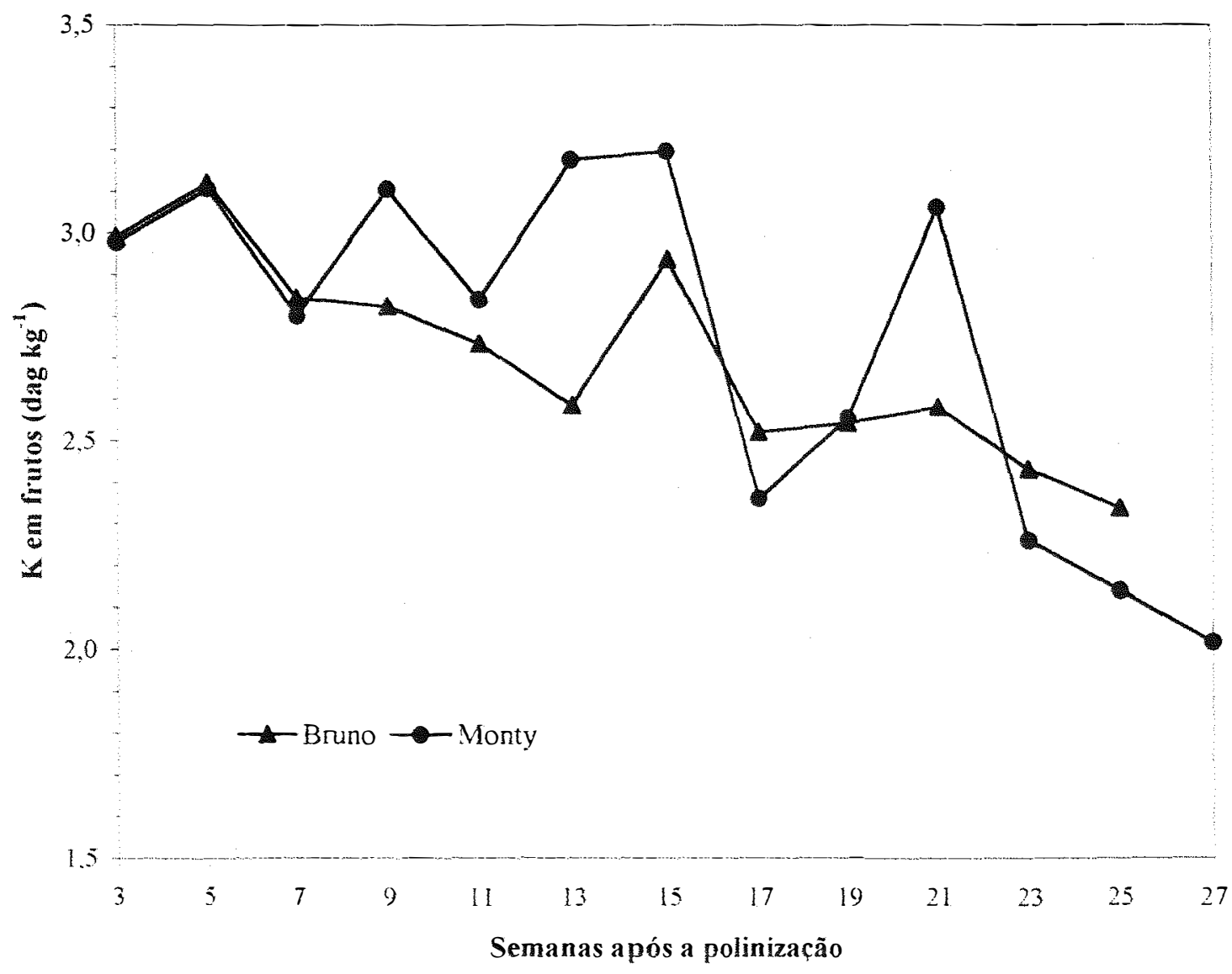

Figura 12. Concentração de potássio nos frutos nos cultivares Bruno e Monty de kiwi, nas épocas de amostragem, no experimento de campo. 
A extração de potássio pelos frutos apresentou os mais baixos valores no início das amostragens e seu maior valor na época de colheita final dos frutos. De maneira geral, os valores encontrados para 'Monty' foram ligeiramente mais altos do que para 'Bruno'. Os menores e maiores valores médios encontrados para o cultivar Bruno foram 10,994 mg na primeira amostragem e 422,088 mg de potássio na última época de amostragem: para o cultivar Monty foram 15,094 $\mathrm{mg}$ também na primeira época e 477,595 mg na décima época de amostragem (Figura 13).

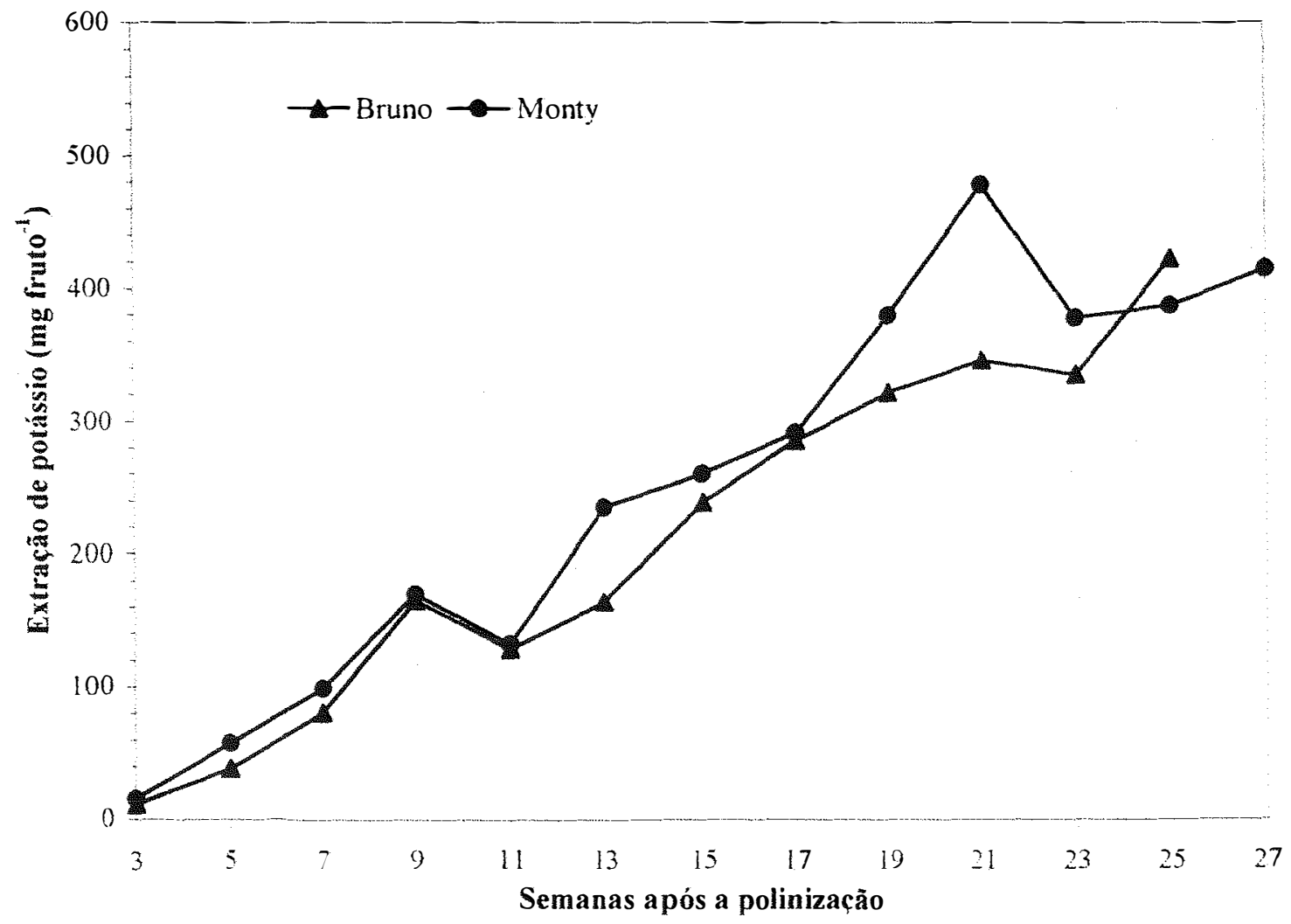

Figura 13. Extração de potássio por frutos nos cultivares Bruno e Monty de kiwi, nas épocas de amostragem, no experimento de campo. 


\subsubsection{Cálcio}

As concentrações de cálcio nas folhas amostradas apresentaram-se mais elevadas no final das épocas de amostragens do que no seu início, com diversas oscilações; no geral, para 'Monty' foram sempre mais elevadas do que as encontradas para 'Bruno'. Em 'Monty' as concentrações de cálcio foram crescentes até a quarta época de amostragem (nona semana após a polinização). Esses teores foram incrementados na vigésima terceira e na vigésima quinta semanas. Em 'Bruno' houve aumento nas concentrações foliares de cálcio a partir da segunda época (quinta semana) de amostragem até a quinta época (décima primeira semana), quando decresceram levemente até a sétima amostragem feita na décima quinta semana. Na oitava época (décima sétima semana), ocorreu um decréscimo acentuado nos teores, que retornaram aos patamares anteriores a partir da amostragem seguinte décima nona semana até o final. Os menores e maiores valores médios encontrados foram $1,178 \mathrm{dag} \mathrm{kg}^{-1} \mathrm{e}$ 1,605 dag kg ${ }^{-1}$ para 'Bruno' e 1,113 dag kg-1 e 2,099 dag kg ${ }^{-1}$ para 'Monty' (Figura 14).

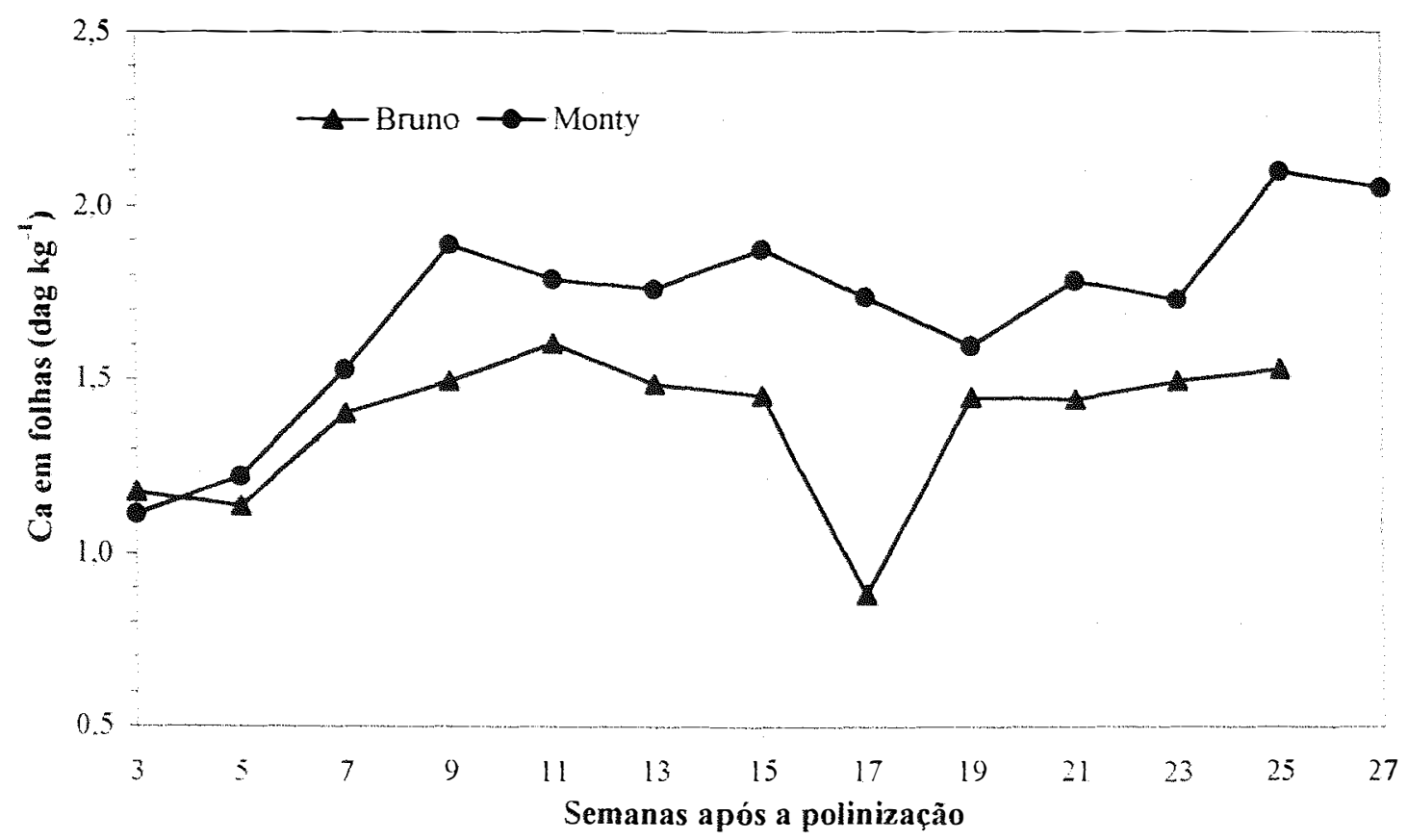

Figura 14. Concentração de cálcio em folhas nos cultivares Bruno e Monty de kiwi, nas épocas de amostragem, no experimento de campo. 
Em frutos, as concentrações de cálcio de maneira geral decresceram do início para o fim das coletas, tendo ocorrido para 'Bruno' uma elevação abrupta também na oitava época de amostragem (décima sétima semana). O comportamento desses teores para os dois cultivares foi paralelo, tendo sido os encontrados para 'Bruno' ligeiramente mais elevados que aqueles para 'Monty'. Entre os valores médios, o menor e maior encontrados para 'Bruno' foram 0,139 dag kg-1 e 0,843 dag kg ${ }^{-1}$ e, para 'Monty', foram 0,116 dag kg-1 e 0,387 $\mathrm{dag} \mathrm{kg}^{-1}$ respectivamente (Figura 15).

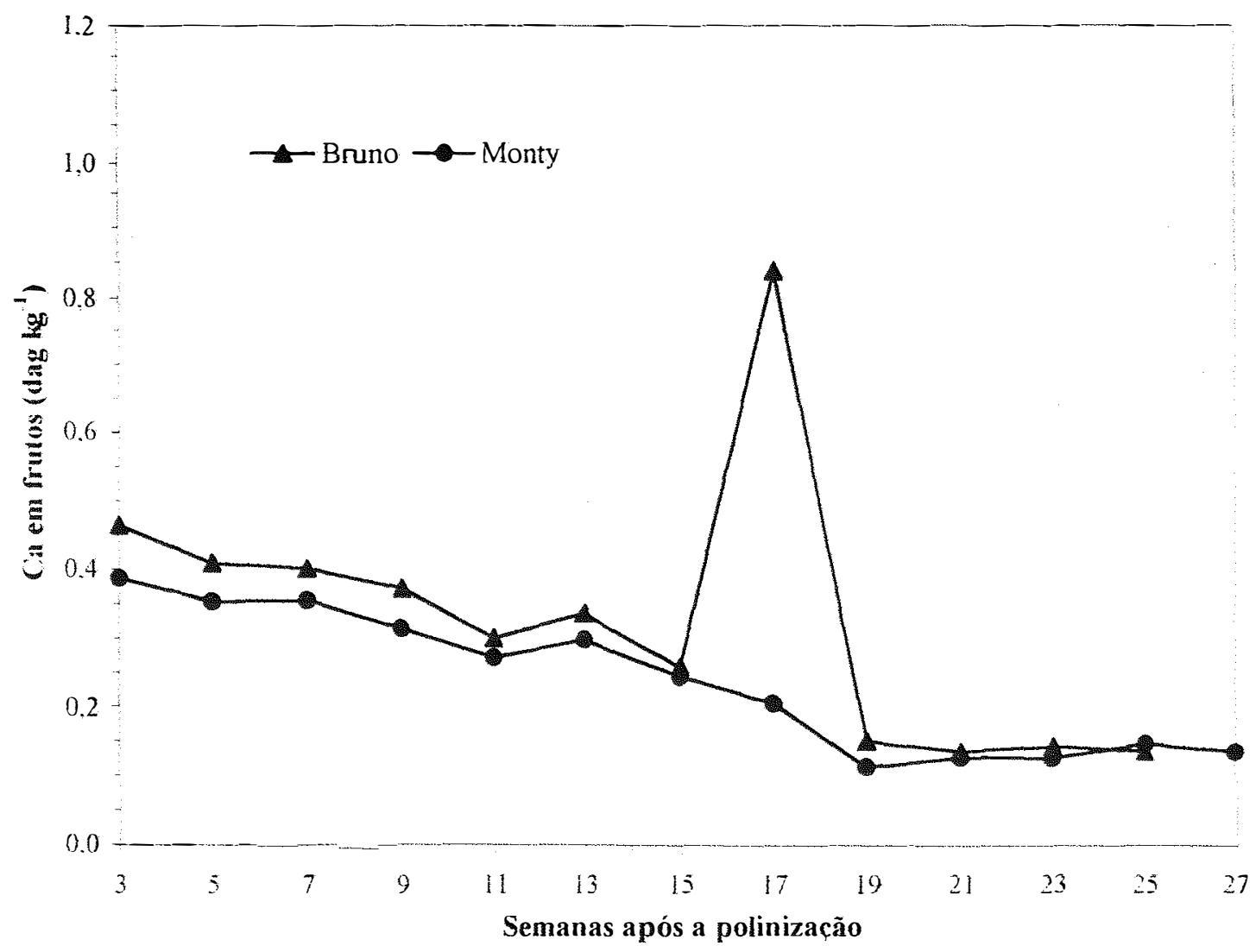

Figura 15. Concentração de cálcio nos frutos nos cultivares Bruno e Monty de kiwi, nas épocas de amostragem, no experimento de campo. 
A extração de cálcio por frutos aumentou desde o início até o fim da colheita em ambos os cultivares, tendo ocorri4o valores altos na oitava época de amostragem (décima sétima semana), para o cultivar 'Bruno'. Os valores para ambos os cultivares caminharam paralelamente, sofrendo um aumento para 'Bruno' por volta da décima sétima semana. No início de crescimento dos frutos, foram encontradas as extrações médias de 1,656 mg de cálcio para 'Bruno' e 1,917 mg para 'Monty', e, no final do ciclo, foram encontrados os maiores valores médios: 25,290 mg de cálcio para 'Bruno' e 28,501 mg para 'Monty'; excetuando-se o valor alto encontrado na oitava época de amostragem (décima quinta semana) para o cultivar 'Bruno', de 93,982 mg de cálcio (Figura 16).

O decréscimo na concentração de cálcio em folhas de 'Bruno' ocorrido na oitava época de amostragem, em concomitância com o aumento na concentração de cálcio em frutos desse cultivar, sugere uma possivel translocação desse nutriente das folhas para os frutos nessa época.

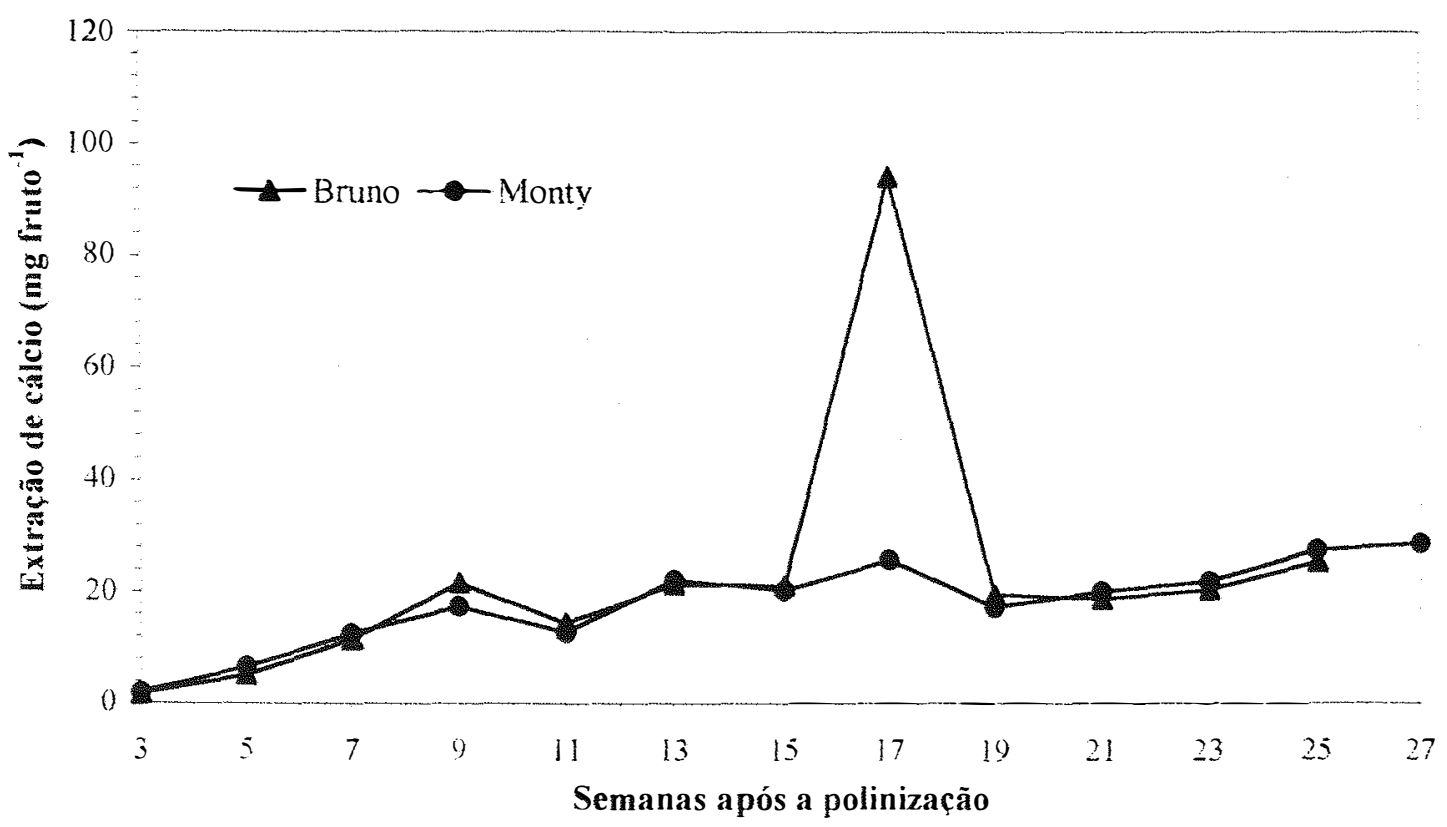

Figura 16. Extração de cálcio por frutos nos cultivares Bruno e Monty de kiwi, nas épocas de amostragem, no experimento de campo. 


\subsubsection{Magnésio}

As concentrações de magnésio nas folhas amostradas foram mais elevadas no final do ciclo que no seu início, tendo os valores apresentados pelo cultivar 'Monty' superado os apresentados pelo cultivar 'Bruno' a partir da nona semana após a polinização. Os valores médios apresentados pelo cultivar 'Monty variaram de $0,354 \mathrm{dag} \mathrm{kg}^{-1}$ a $0,689 \mathrm{dag} \mathrm{kg}^{-1}$ e os médios apresentados por 'Bruno' oscilaram entre $0,358 \mathrm{dag} \mathrm{kg}^{-1}$ (na décima sétima semana ou oitava época de coleta) e $0,555 \mathrm{dag} \mathrm{kg}^{-1}$. Verificou-se uma queda acentuada nos valores médios da oitava época de amostragem (décima sétima semana após a polinização), para o cultivar Bruno (Figura 17).

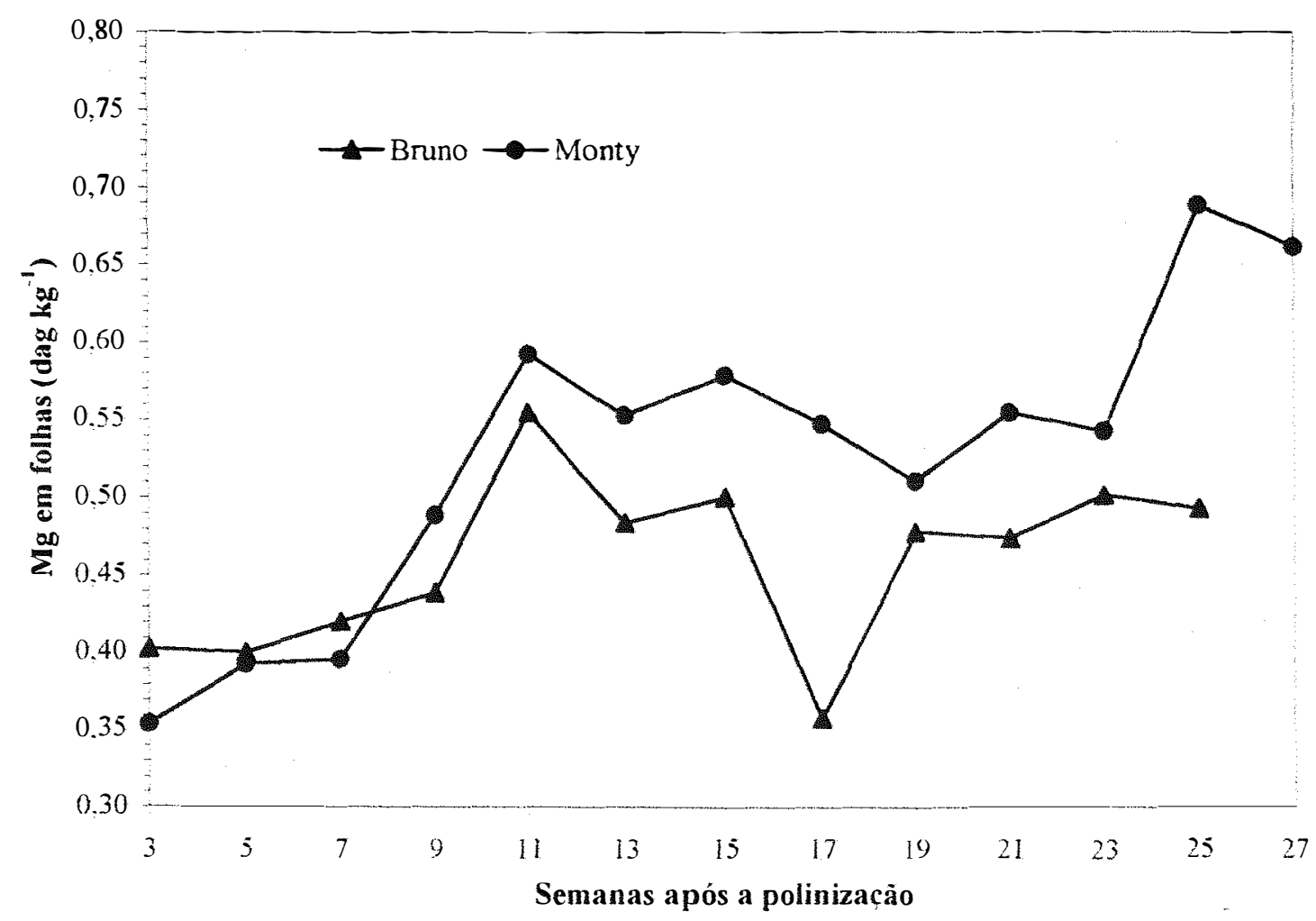

Figura 17. Concentração de magnésio nas folhas nos cultivares Bruno e Monty de kiwi, nas épocas de amostragem, no experimento de campo. 
Em frutos, as concentrações de magnésio decresceram, no geral, do início ao fim do período de amostragem, tendo ocorrido valores altos na oitava época de amostragem correspondente à décima sétima semana para o cultivar Bruno. Em média, os valores para 'Bruno' oscilaram entre $0,304 \mathrm{dag} \mathrm{kg}^{-1}$ a $0,110 \mathrm{dag} \mathrm{kg}^{-1}$, excetuando-se o valor da oitava data de amostragem, que foi de $0,325 \mathrm{dag} \mathrm{kg}^{-1}$. Para o

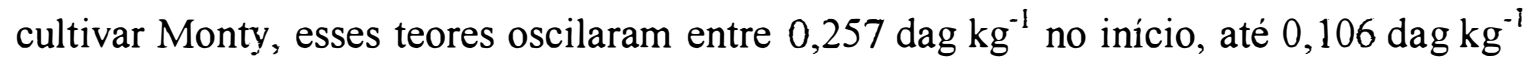
no final do ciclo (Figura 18).

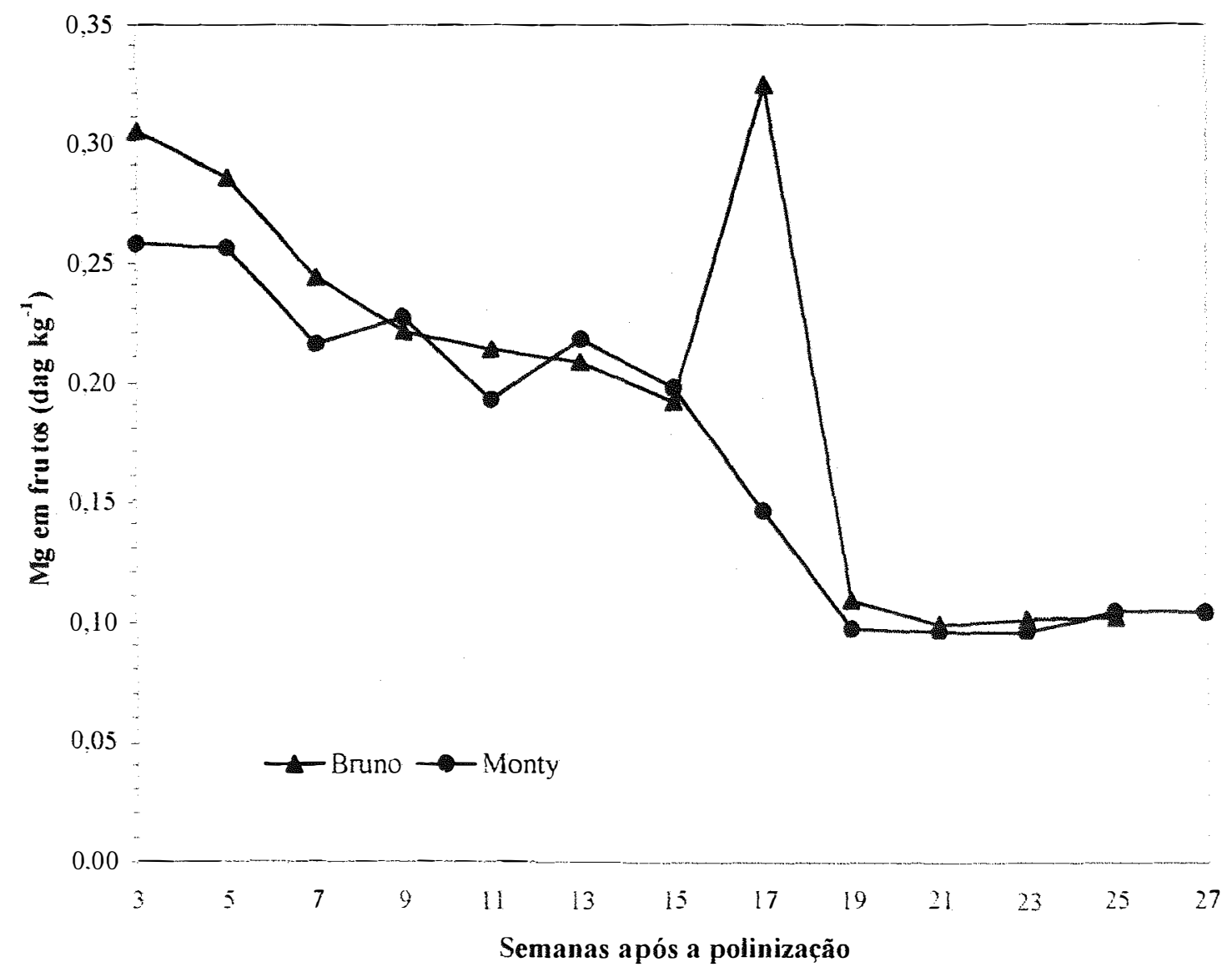

Figura 18. Concentração de magnésio nos frutos nos cultivares Bruno e Monty de kiwi, nas épocas de amostragem, no experimento de campo. 
A extração de magnésio por frutos aumentou do início ao fïm do ciclo. Os valores para o cultivar Bruno foram de $1,091 \mathrm{mg}$ de magnésio no início da coleta e de $18,752 \mathrm{mg}$ ao final, ocorrendo o valor alto na oitava época de amostragem desse cultivar, que revelou extração de $36,523 \mathrm{mg}$ de magnésio por fruto. Para o cultivar Monty, o valor médio inicial e menor foi de $1,289 \mathrm{mg}$ e o final de $21,610 \mathrm{mg}$ de magnésio (Figura 19).

O decréscimo na concentração de magnésio em folhas do cultivar Bruno ocorrido na oitava época de amostragem e o simultâneo aumento na concentração desse nutriente em frutos permite supor que se tenha dado em função de uma possível transformação desse nutriente das folhas para os frutos nessa época.

A ordem de extração dos nutrientes foi a seguinte: $\mathrm{K}>\mathrm{N}>\mathrm{P}>\mathrm{Ca}>\mathrm{Mg}$.

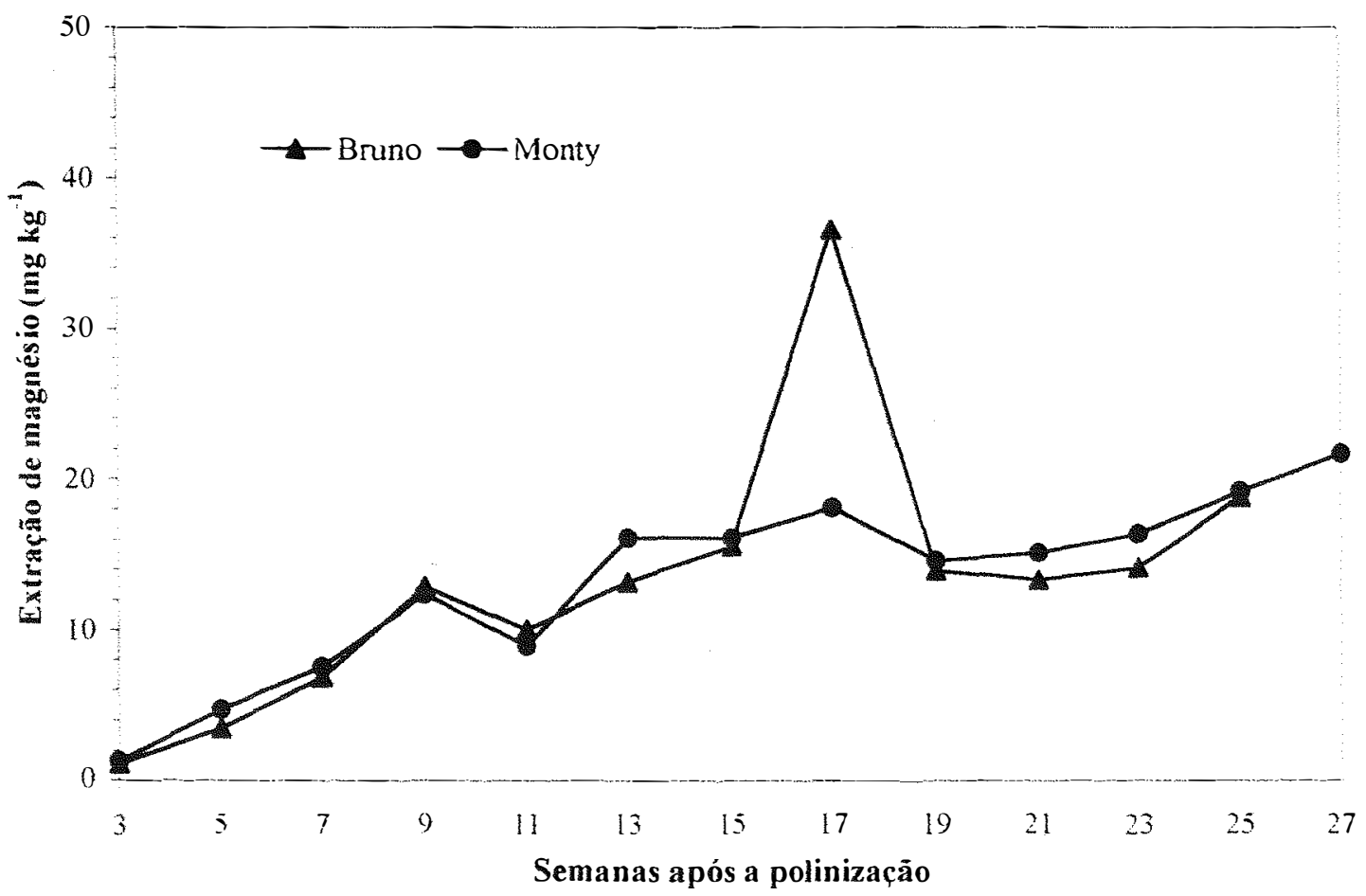

Figura 19. Extração de magnésio por frutos nos cultivares Bruno e Monty de kiwi, nas épocas de amostragem, no experimento de campo. 


\subsubsection{Correlações}

\subsubsection{Teores de nutrientes na folha amostrada e peso de fruto}

Considerando-se todas as épocas de amostragem em conjunto, as correlaçòes entre os teores dos macronutrientes estudados e os pesos de frutos no cultivar Bruno mostraram o seguinte comportamento: negativa $(-0,64)$ para os teores foliares de nitrogènio e pesos de frutos; negativa $(-0,38)$ entre os teores foliares de potássio e pesos de frutos; positiva $(0,35)$ entre teores foliares de fósforo e pesos de frutos, e, não significativa quanto aos teores foliares de cálcio e magnésio e pesos de frutos.

Considerando-se cada uma das épocas de amostragem em separado, as correlações entre os teores dos macronutrientes estudados e os pesos individuais de frutos não foram significativas $(\mathrm{P}>0,05)$ para o cultivar Bruno, com exceção da correlação entre o teor foliar de nitrogènio e o peso de fruto na vigésima primeira semana, que foi negativa $(-0,76)$. Quanto ao cultivar Monty, consideradas todas as épocas de amostragem em conjunto, as correlações entre os teores foliares de nitrogènio e de potássio e pesos de frutos mostraram-se ambas negativas (-0,82 e - $-0,71$, respectivamente). A correlação entre teores foliares de fósforo e pesos de frutos mostraram-se positivas $(0,32)$, assim como entre teores de cálcio na folha e pesos de frutos $(0,59)$. A correlação entre teor de magnésio na folha e pesos de frutos mostrou-se positiva $(0,67)$. 
Ainda para o cultivar Monty, consideradas as épocas de amostragem em separado, apenas foram significativas algumas dessas correlações a partir da décima época (vigésima primeira semana). Nesta época, apenas a correlação entre o teor de potássio na folha e o peso individual de frutos mostrou-se negativa $(-0,80)$ sendo não

significativa nas épocas seguintes. A correlação entre o teor de cálcio na folha e o peso seco individual de frutos do cultivar Monty mostrou-se negativa $(-0,76)$ na décima primeira época (vigésima terceira semana), sendo não significativa nas demais. A correlação entre o teor de magnésio na folha e o peso seco individual de frutos do cultivar Monty mostrou-se negativa $(-0,83)$ na décima primeira época (vigésima terceira semana), sendo não significativa nas demais.

\subsubsection{Teores de nutrientes na folha amostrada e teores de nutrientes no fruto}

As correlações entre os teores de macronutrientes estudados na folha amostrada e no fruto, considerando-se todas as épocas de amostragem em conjunto no cultivar Bruno, tiveram o seguinte comportamento: positivas para os nutrientes nitrogênio $(0,51)$ e potássio $(0,37)$ e não significativas $(P>0,05)$ para fósforo, cálcio e magnésio.

Considerando-se cada época de amostragem em separado, essas correlações no cultivar Bruno foram as seguintes: houve correlação positiva entre os teores de nitrogènio na folha e no fruto nas cinco primeiras épocas de amostragem, 
compreendidas desde a terceira até a décima primeira semana após a polinização $(0,81$; 0,$88 ; 0,85 ; 0,87 ; 0,82$ respectivamente) e também na oitava época, décima sétima semana $(0,98)$. Houve correlação positiva entre os teores de fósforo na folha e no fruto nas três primeiras épocas de amostragem, desde a terceira até a sétima semana $(0,95$; 0,$75 ; 0,77$ respectivamente) e na oitava época, décima sétima semana $(0,83)$. Para os teores de potássio existiu correlação positiva do teor nos frutos com o teor nas folhas, na nona época de amostragem, décima nona semana $(0,74)$, enquanto para os teores de cálcio houve correlação positiva na oitava e na nona época de amostragem, ou seja, décima sétima e décima nona semanas $(0,99$ e 0,85 respectivamente). Para os teores de magnésio nas folhas e frutos, ocorreram correlações positivas na sexta, oitava e nona épocas de amostragem $(0,73 ; 0,93 ; 0,62$ respectivamente), correspondentes à décima terceira, décima sétima e décima nona semanas.

Quanto ao cultivar Monty, consideradas todas as épocas de amostragem em conjunto, foi positiva a correlação entre os teores de nitrogênio na folha e no fruto $(0,68)$, não significativa $(P>0,05)$ a correlação entre os teores de fósforo; positiva a correlação entre os teores de potássio $(0,58)$; e correlação negativa tanto entre os teores de cálcio na folha e no fruto $(-0,48)$, como entre os teores de magnésio $(-0,57)$. Nesse cultivar, consideradas as épocas de amostragem separadamente, não foram significativas $(P>0,05)$ as correlações entre os teores na folha e no fruto dos macronutrientes nitrogênio, potássio e magnésio. Houve correlação positiva entre os teores de fósforo nas folhas e frutos na primeira e quarta época de amostragem $(0,92$ e 0,86 respectivamente), correspondentes à terceira e à nona semanas e, entre os teores de 
cálcio na quinta época, correspondente à décima primeira semana após a polinização $(0,83)$

\subsubsection{Teores de nutrientes na folha amostrada e extração de nutrientes pelo fruto}

Em cultivar Bruno, consideradas todas as épocas conjuntamente, ocorreram correlações negativas entre o teor de nitrogènio na folha e sua extração pelo fruto $(-0,54)$ e entre o teor de potássio na folha e sua extração pelo fruto $(-0,32)$ Foram positivas as correlações entre os teores nas folhas para o fósforo $(0,39)$, cálcio $(0,18)$ e magnésio $(0,26)$ e suas respectivas extrações pelos frutos.

Considerando-se cada época de amostragem em separado, para o cultivar Bruno, as correlações foram positivas para os teores de nitrogènio na folha e sua extração pelo fruto na terceira, quarta e oitava épocas (respectivamente: 0,$83 ; 0,85$ e 0,95), correspondentes às sétima, nona e décima sétima semanas. Também houve correlações positivas para o fósforo na oitava época ou décima sétima semana $(0,79)$ e para o potássio na décima primeira época $(0,73)$ correspondente à vigésima terceira semana. Foram também positivas as correlações, considerando-se o cálcio na décima sétima e décima nona semanas ou oitava e nona épocas $(0,99$; e 0,84$)$ e o magnésio nas seguintes épocas: quarta, sexta, oitava, nona e décima segunda (respectivamente: 0,88 ; $0,73 ; 0,94: 0,66 ; 0,74)$, correspondentes à nona, décima terceira, décima sétima, décima nona e vigésima quinta semanas. 
Para o cultivar Monty, consideradas todas as épocas conjuntamente, foi negativa a correlação entre o teor foliar de nitrogènio e sua extração pelo fruto $(-0,783)$, assim como a correlação entre o teor foliar de potássio e sua extração pelo fruto $(-0,607)$. Foram positivas tanto as correlações entre os teores foliares de cálcio e magnésio e suas respectivas extrações pelos frutos $(0,73$ e 0,72$)$ como a correlação entre o teor foliar de fósforo e sua extração pelo fruto $(0,41)$.

Consideradas as épocas de amostragem em separado, para o cultivar Monty, apenas foram significativas as seguintes correlações entre o teor foliar do macronutriente e sua extração pelo fruto: para nitrogênio, a correlação foi positiva na décima primeira época $(0,87)$; para fósforo e cálcio, foram negativas na décima primeira época $(-0,76$ e $-0,80)$, correspondente à vigésima terceira semana e, para magnésio, foi negativa na décima primeira época $(-0,87)$ e positiva na última época de amostragem $(0,81)$. 


\section{CONCLUSÕES}

1- A sintomatologia obtida na deficiència de macronutrientes revelou: clorose das folhas velhas seguidas de manchas necróticas no limbo, além de menor crescimento da planta, quando da omissão de nitrogènio; lesões marrons nas folhas mais velhas, quando da omissão de potássio; manchas cloróticas entre as nervuras que permaneceram verdes, quando houve omissão de magnésio e clorose de folhas novas quando da omissão de enxofre;

2- As concentrações de nitrogènio e potássio na folha adjacente ao fruto decresceram com o passar do tempo após a polinização;

3- As concentrações de N, P, K, Ca e Mg nos frutos foram mais baixas nas semanas próximas ao ponto de maturação do que nas primeiras semanas após a polinização;

4- As concentrações de fósforo e potássio foram mais elevadas nas folhas adjacentes aos frutos no cultivar Bruno, enquanto o mesmo aconteceu com o nitrogènio, cálcio e magnésio para o cultivar Monty;

5- A concentração e a extração de nitrogènio nos frutos foram mais elevadas no cultivar Monty que no cultivar Bruno: 
6- As concentrações e as extrações de $\mathrm{P}, \mathrm{K}, \mathrm{Ca}$ e $\mathrm{Mg}$ nos frutos foram similares nos cultivares Bruno e Monty durante o desenvolvimento dos mesmos;

7- As quantidades extraídas de nutrientes pelos frutos nos cultivares Bruno e Monty seguiram a ordem: $\mathrm{K}>\mathrm{N}>\mathrm{P}>\mathrm{Ca}>\mathrm{Mg}$. 


\section{REFERÊNCIAS BIBLIOGRÁFICAS}

ASHER, C.J.; SMITH, G.S.; CLARK, C.J.; BROWN, N.S. Manganese deficiency of kiwifruit (Actinidia chinensis Planch.). Journal of Plant Nutrition, London,7: 1497-509, 1984.

BATAGLIA, O.C. Determinação indireta de enxofre em plantas por espectrofotometria de absorção atômica. Ciência e Cultura, São Paulo, 28 (6): 672-5, jun. 1976.

BATTELLI, G.\& RENZI, G. A nutritional survey of kiwi orchards in northern Italy. In: INTERNATIONAL SYMPOSIUM ON KIWIFRUIT, Padova, 1987. Acta Horticulturae, Wagenigen, 282: 173-85, 1990.

BRASIL. Ministério da Agricultura. Divisão de Pesquisa Pedologica. Levantamento exploratório-reconhecimento de solos do Estado de São Paulo. Rio de Janeiro, 1960. 634p. (SNPA. Boletim, 12).

BUWALDA, J.G.; WILSON, G.J.; SMITH, G.S; LITTLER, R.A. The development and effects of nitrogen deficiency in field-grown kiwifruit (Actinidia deliciosa) vines. Plant and Soil, The Hague, 129, 173-82, 1990.

CLARK, C.J. \& SMITH, G.S. Magnesium deficiency of kiwifruit (.Actinidia deliciosa). Plant and Soil, The Hague, 104, 281-89, 1987.

CLARK, C.J. \& SMITH, G.S. Seasonal accumulation of mineral nutrients by kiwifruit 2.Fruit. New Phytologist, London, 108:399-409, 1988.

CRESSWELL, G.C. Development of a leaf sampling technique and leaf standards for kiwifruit in New South Wales. Australian Journal of Experimental Agriculture, East Melbourne, 29: 411-7, 1989. 
EPSTEIN, E. Nutrição mineral das plantas; princípios e perspectivas. Rio de Janeiro, Livros Técnicos e Científicos; São Paulo, EDUSP, 1974. 341 p.

FENAROLl, L.. Un frutto d'avvenire Actinidia notizie sul genere e sua coltivazione. Itália Universale Edagricole, 1982. 64p..

FERGUSON, A.R. Kiwifruit: a botanical review. Horticultural reviews, Westport, 6: $1-64,1984$.

FERGUSON, A.R. \& EISEMAN, J.A.. Estimated annual removal of macronutrients in fruit and prunings from a kiwifruit orchard. New Zealand Journal of Agricultural Research, Wellington, 26:115-7. 1983.

FERGUSON, A.R.; TURNER, N.A.; BANK, R.J. Management and nutrition of kiwifruit vines. Journal of Plant Nutrition, London, 10 (9/16): 1531-37, 1987.

FERGUSON, I.B. Movement of mineral nutrients into the developing fruit of the kiwifruit (Actinidia chinensis Planch.). New Zealand Journal of Agricultural Research, Wellington, 23:349-53, 1980.

GIORGIO, V; STANDARDI, P, MAGNIFICO, V; SANTAMARIA, P SERIO, F.; Analisi fogliare di actinidia allevata in Puglia. Rivista di Fruticoltura, Bologna, 9 , 1992.

GRANT, J.A. \& RYUGO, K.. Influence of within - canopy shading on fruit size, shoot growth and return bloom in kiwifruit. Journal of the American Society for Horticultural Science, Alexandria, 109 (6):799-802. 1984.

KOTZÉ, W.A.G. \& VILLIERS, J. de. Seasonal uptake and distribution of nutrient elements by kiwifruit vines 1.Macronutrients. South African Journal of Plant and Soil, Pretoria, 6 (4) :256-64, 1989.

LALATTA, F. Lavorazioni e concimazione per l' Actinidia. Separata de Agricoltura Ricerca, Roma, 53: 53-62, 1985.

LALATTA, F.: VISAI, C.: FAILLA, O. Application of leaf analysis on kiwifruit orchards in northern Italy. In: INTERNATIONAL SYMPOSIUM ON KIWIFRUIT, Padova, 1987. Acta Horticulturae, Wagenigen, 282:187-97, 1990. 
LIONAKIS, S.M. \& SCHWABE, W.W. Some effects of mineral nutrient deficiencies on the growth of Actinidia chinensis Planch. Journal of Horticultural Science, London, 60: 411-22, 1985.

MARSH, K.B.; STOWELL, B.M; TILLMAN, R.W. Options for supplying potassium to kiwifruit vines. In: INTERNATIONAL SYMPOSIUM ON KIWIFRUIT, 2., Palmerston North, 1991. Acta Horticulturae, Wagenigen, 297:337-43, Apr. 1991.

MONETTE, P.L. Cold storage of kiwifruit shoot tips in vitro. HortScience, Alexandria, $21(5): 1203-05,1986$.

POVES, L.T.. El Quivi o Actinidia. Madrid, Hojas Divulgadoras del Ministerio de Agricultura, Pesca y Alimentación, 1982. 24p.

RAIJ, B. van; QUAGGIO, J.A.; CANTARELLA, H. FERREIRA, M.E.; LOPES, A.S.; BATAGLIA, O.C. Análise química do solo para fins de fertilidade. Campinas, Fundação Cargill, 1987. 170 p.

SALE, P.R. Kiwifruit culture. Wellington, New Zealand,Government Printer, 1985. 96p.

SARRUGE, J.R.; Soluções nutritivas. Summa Phytopathologica, Piracicaba, 1 (3): $231-33,1975$.

SARRUGE, J.R. \& HAAG, H.P. Análise química em plantas, Piracicaba, ESALQ, $1974,55 \mathrm{p}$.

SCHUCK, E. Cultivares de quivi. Agropecuária Catarinense, Florianópolis, 5 (4): 912,1992

SHEAR, C.B. \& FAUST, M. Nutritional ranges in deciduous tree fruits and nuts. Horticultural Reviews, Westport, 2: 142-63, 1980.

SMITH, G.S.; CLARK, C.J.; BUWALDA, J.G.C. Potassium and phosphorus effect of potassium deficiency on kiwifruit. Journal of Plant Nutrition, London, 10 (9/16): $1939-46,1987 \mathrm{a}$.

SMITH, G.S.; CLARK, C.J.; HENDERSON, H.V. Seasonal accumulation of mineral nutrients by kiwifruit I. Leaves. New Phytologist, London, 106: 81-100, 1987b. 
TAGLIA VINI, M; SCUDELLARI, D; MARANGONI, B; BASTIANEL, A.; FRANZIN, F.; ZAMBORLINI, M. Leaf mineral composition of apple tree: sampling date and effects of cultivar and rootstock. Journal of Plant Nutrition London, 15 (5): 605-19, 1992.

ZUCCHERELli, G. \& ZUCCHERELLI, G. L'Actinidia pianta da frutto e da giardino. Bologna, Edagricole, 1981. 198p. (Frutticoltura Moderna - Collana di Manuali Tecnici Dell' Edagricole) 